Editoras/es

$$
\begin{aligned}
& \text { Sara Marta Miguel } \\
& \text { Pérez-Rodríguez-Túnez- } \\
& \text { Seijo Castro López }
\end{aligned}
$$

Prólogo:

Miguel Túñez-López/Francisco Campos-Freire

\title{
Debates sobre valores e indicadores del servicio audiovisual público en Europa
}

Cuadernos Artesanos de Comunicación / 142

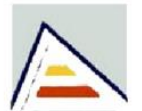

Universitat d'Alacant Universidad de Alicante

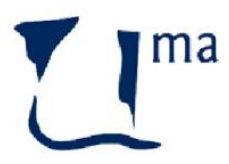

UNIVERSIDAD DE M Á A G A

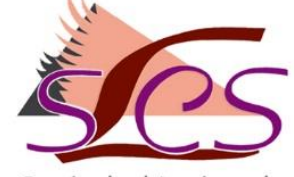

Sociedad Latina de Comunicación Social 


\section{Cuadernos Artesanos de Comunicación}

Coordinador editorial: José Manuel de Pablos - jpablos@ull.edu.es

Comité Científico

Presidencia: José Luis Piñuel Raigada (UCM)

Secretaría: Milena Trenta

- Miguel Vicente (Universidad de Valladolid, UVA)

- Ramón Zallo (Universidad del País Vasco, UPV-EHU)

- Núria Almiron (Universidad Pompeu Fabra, UPF)

- José Cisneros (Benemérita Universidad Autónoma de Puebla, BUAP)

- Bernardo Díaz Nosty (Universidad de Málaga, UMA)

- Carlos Elías (Universidad Carlos III de Madrid, UC3M)

- Paulina B. Emanuelli (Universidad Nacional de Córdoba, UNC)

- José Luis González Esteban (Universitat Miguel Hernández de Elche, UMH)

- Marisa Humanes (Universidad Rey Juan Carlos, URJC)

- Juan José Igartua (Universidad de Salamanca, USAL)

- Maricela López-Ornelas (Universidad Autónoma de Baja California, AUBC)

- Javier Marzal (Universidad Jaume I, UJI)

- José Antonio Meyer (Benemérita Universidad Autónoma de Puebla, BUAP)

- Ramón Reig (Universidad de Sevilla, US)

- Miquel Rodrigo Alsina (Universidad Pompeu Fabra, UPF)

- Xosé Soengas (Universidad de Santiago de Compostela)

- José Luis Terrón (Universidad Autónoma de Barcelona, UAB)

- Victoria Tur (Universidad de Alicante, UA)

* Queda expresamente autorizada la reproducción total o parcial de los textos publicados en este libro, en cualquier formato o soporte imaginables, salvo por explícita voluntad en contra del autor o autora o en caso de ediciones con ánimo de lucro. Las publicaciones donde se incluyan textos de esta publicación serán ediciones no comerciales y han de estar igualmente acogidas a Creative Commons. Harán constar esta licencia y el carácter no venal de la publicación.

Este libro y cada uno de los capítulos que contiene (en su caso), así como las imágenes incluidas, si no se indica lo contrario, se encuentran bajo una Licencia Creative Commons Atribución-No Comercial-Sin Derivadas 3.0 Unported. Puede ver una copia de esta licencia en http://creativecommons.org/licenses/by-nc-nd/3.0/ Esto significa que Ud. es libre de reproducir y distribuir esta obra, siempre que cite la autoría, que no se use con fines comerciales o lucrativos y que no haga ninguna obra derivada. Si quiere hacer alguna de las cosas que aparecen como no permitidas, contacte con los coordinadores del libro o con el autor del capítulo correspondiente.

* La responsabilidad de cada texto es de su autor o autora. 


\section{Editoras/es}

Sara Pérez-Seijo, Marta Rodríguez-Castro,

Miguel Túñez-López

Prólogo: Miguel Túñez-López/Francisco Campos-Freire

Debates sobre valores e

indicadores del servicio audiovisual público en

Europa

Cuadernos Artesanos de Comunicación / 142

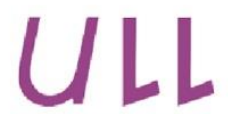

Universidad de La Laguna

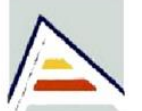

Universitat d'Alacant Universidad de Alicante

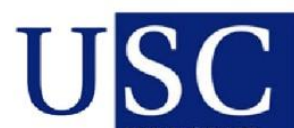

UNIVERSIDADE DE SANTIAGO
DE COMPOSTEL

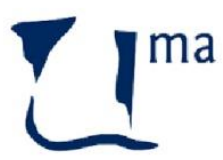

UNIVERSIDAD

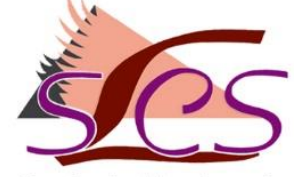

Sociedad Latina de Comunicación Social 
CAC $142^{\circ}$ - Debates sobre valores e indicadores del servicio audiovisual público en Europa

Editoras/es del CAC 142 Sara Pérez-Seijo, Marta Rodríguez-Castro y Miguel Túñez-López

| Precio social: 8,00€ | Precio en librería. 10,40€ |

Editores: Javier Herrero y Milena Trenta

Diseño: F. Drago

Ilustración de portada: Fragmento del cuadro "Mujer de

Fuenteventura", de Vale (Bolonia).

Imprime y distribuye: F. Drago. Andocopias S. L.

c/ La Hornera, 41. La Laguna. Tenerife.

Teléfono: 922250554 | fotocopiasdrago@telefonica.net

Edita: Sociedad Latina de Comunicación Social - edición no venal

- La Laguna (Tenerife), 2017 - Creative Commons

http://www.revistalatinacs.org/14SLCS/portada2014.html

Descargar en pdf:

http://www.cuadernosartesanos.org/\#142

Protocolo de envío de manuscritos con destino a CAC: (la colección que corresponda)

http://www.cuadernosartesanos.org/protocolo.html

ISBN: 978-84-17314-01-9

DL: TF-688-2018

DOI: $10.4185 / \operatorname{cac} 142$ 


\section{Índice}

Prólogo. La innovación digital y la renovación 3P: públicos, plataformas y programas

Miguel Túñez-López y Francisco Campos Freire

1. Acciones de innovación de las radiotelevisiones públicas europeas

Valentín-Alejandro Martínez-Fernández, Óscar Juanatey-Boga y

Verónica Crespo-Pereira

2. Diseño, verificación, visualización de la información e inclusión social en los libros de estilo de cinco radiotelevisiones públicas de referencia en Europa

Jorge Vázquez-Herrero, Ángel Vizoso y Xosé López-García.

3. El servicio audiovisual público como memoria y patrimonio documental

Mercedes Caridad Sebastián, Sara Martínez Cardama, Fátima García

López y Ana María Morales García.

4. El servicio audiovisual público en la era de la post-emisión Francisco Campos-Freire.

5. La regulación de los debates electorales en el servicio audiovisual público

José Rúas-Araújo, José Fernández-Holgado y José Ángel AlénAmil

6. La reputación del servicio audiovisual público en la era posttv. El caso RTVE

Carmen Costa-Sánchez.

7. Las narrativas inmersivas como valor de innovación en las radiotelevisiones públicas europeas

Sara Pérez-Seijo y María José Benítez de Gracia.

8. Legislar la participación en la televisión pública.

Recomendaciones a partir de los modelos europeos

Ana María López-Cepeda 
9. Monitorización de las radiotelevisiones públicas de España y Portugal en Facebook

María-Magdalena Rodríguez-Fernández y Eva Sánchez-

Amboage

10. Modelos y tendencias de la radiotelevisión pública regional europea

Marta Rodríguez-Castro y Mónica López-Golán

Los autores y las autoras

El contenido de este libro ha sido sometido a un proceso de revisión de doble ciego por pares, semejante al sistema de revisión de un artículo científico para un journal. 


\title{
Debates sobre valores e indicadores del servicio audiovisual público en Europa
}

\author{
Editoras/es: Sara Pérez-Seijo, Marta Rodríguez-Castro \\ y Miguel Túñez-López
}

\section{Resumen:}

Este Cuaderno Artesano de Comunicación (CAC) es el segundo de la trilogía de publicaciones planteada con motivo de la celebración del I Simposio Internacional de Revista Latina de Comunicación Social en septiembre de 2018. Tres documentos que tienen como finalidad última dibujar un mapa que ilustre el estado actual del servicio audiovisual público en Europa y exhiba los últimos avances, en cuanto a innovación se refiere, en el campo del periodismo.

Bajo el título "Debates sobre valores e indicadores del servicio audiovisual público en Europa", este CAC aúna 10 estudios tanto teóricos como prácticos centrados en temas como la incidencia de la innovación, la identificación de experiencia, la revisión de los marcos normativos, la presencia de las radiotelevisiones en las redes sociales y las estrategias para promover una reputación favorable.

Expertos de seis universidades (Universidad de Castilla-La Mancha, Universidade de Vigo, Universidade da Coruña, Universidad Carlos III de Madrid, Pontificia Universidad Católica del Ecuador sede Ibarra y Universidade de Santiago de Compostela) han participado en la confección de este Cuaderno centrado en los valores e indicadores del servicio audiovisual público europeo. Gracias al trabajo, interés y esfuerzo colectivo, esta inquietud se ha podido materializar en el presente documento.

Palabras clave: innovación, televisiones públicas europeas, gobernanza, indicadores de calidad, SAP.

\section{Forma de citar este libro:}

Pérez-Seijo, S., Rodríguez-Castro, M. y Túñez-López, M. (Eds.) (2018). Debates sobre valores e indicadores del servicio audiovisual público en Europa. Cuadernos Artesanos de Comunicación, cac 142. La Laguna (Tenerife): Latina. DOI: $10.4185 /$ cac142 



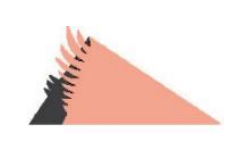

\section{Prólogo}

\section{La innovación digital y la renovación 3P: públicos, plataformas y programas}

La estrategia digital ha dejado de ser una mera cuestión tecnológica y se ha convertido en un motor de transformación cultural y estructural que está presente en los modelos de gestión que están materializando las radiotelevisiones públicas europeas más avanzadas. La máxima es Digitization first, es decir, organizar, financiar, producir y emitir contenidos en primer lugar a través de las plataformas de Internet en lugar de hacerlo antes a través de los sistemas tradicionales de difusión digital terrestre, cable o satélite.

Esta orientación obliga a crear plataformas propias y, a la vez, promover la presencia en plataformas ajenas para garantizar máximo de puntos de contacto con la audiencia internauta interactiva pero no solo es una cuestión de soporte porque se trata de un cambio que obliga a replantear las ideas sobre los sistemas de difusión, el futuro de la TDT, la producción de contenidos, la programación, la financiación, la organización y el análisis de audiencias, de consumos y de usos.

El concepto de plataforma, como sistema convergente de distribución y comercialización digital, es una revolución (Parker, Alstyne \& Choudary, 2016) de la economía en red que propicia la arquitectura de las tecnologías de la información (Tiwana, 2013) al permitir la conexión directa, sin apenas otros intermediarios, de productores y usuarios, trastocando los modelos de negocio (Osterwalder, 2004) y los mercados audiovisuales tradicionales. Esto afecta a las políticas de regulación de la competencia y obliga a reaccionar a los operadores tradicionales, sean privados o públicos.

La inclusión de las plataformas digitales en las normas europeas de regulación audiovisual de forma equiparable a los medios tradicionales 
es una vieja demanda y una lenta reforma que la revisión de la Directiva 2010/10/UE de Servicios Audiovisuales prevé concluir a finales de 2018. La regulación más estricta y simétrica de las plataformas es una convicción reiterada de los juristas y operadores audiovisuales en los últimos años (Cabrera et al., 2018).

Esa revisión de la Directiva audiovisual europea está dedicada en su mayor parte a los plataformas, que dejan de ser contempladas exclusivamente -como ocurre hasta ahora-como proveedores virtuales de contenidos -bajo la responsabilidad de la Directiva de comercio electrónico y la Carta de Derechos Fundamentales de la UE- para pasar a considerarse también operadores editores e intermediarios audiovisuales, con obligaciones editoriales sobre control de contenidos no adecuados para públicos infantiles o discriminatorios sobre violencia, racismo y xenofobia.

La importancia de la inclusión de las plataformas en la Directiva de Servicios Audiovisuales radica en que dejan de ser meros infomediarios -bien sean intermediarios de vídeo como YouTube o Dailymotion o medios sociales como Facebook o Instagram - para pasar a ser considerados como operadores con responsabilidades editoriales -más allá de las competencias exigidas a través de la normativa del comercio electrónico- en condiciones más simétricas de las existentes hasta ahora con respecto a los prestadores tradicionales de los servicios audiovisuales.

Su incidencia económica en el conjunto de la industria audiovisual es incuestionable. Según el Observatorio Audiovisual Europeo (EAO, 2018) representan el 60\% del sector audiovisual; es decir, un volumen económico de 36.836 millones de euros, sobre un montante de todo el audiovisual de 101.297 millones en 2016, frente a 34.415 millones de la televisión y 14.335 millones de la prensa.

En este contexto, este nuevo CAC recoge aportaciones de expertos de varias Universidades para, como refleja su título, promover el debate sobre los valores y sobre los indicadores del servicio audiovisual público en Europa. A través de diez capítulos se presta atención la incidencia de la innovación, la identificación de experiencia, la revisión de marcos normativos, el análisis de presencia en red y las estrategias para promover una reputación favorable. 
En el primero de ellos, Valentín-Alejandro Martínez-Fernández, Óscar Juanatey-Boga y Verónica Crespo-Pereira revisan las acciones de innovación de las radiotelevisiones públicas europeas como un pilar esencial para el sostenimiento del sistema público al facilitar modelos estratégicos y operativos encaminados a la eficiencia económica, tecnológica y optimización de demandas sociales que evidencian la vigencia y utilidad social de los servicios prestados por la televisión pública.

El segundo capítulo muestra los resultados de la revisión de los libros de estilo de cinco radiotelevisiones públicas europeas de referencia. En él, Xosé López-García, Jorge Vázquez-Herrero y Ángel Vizoso se detienen en analizar las referencias al diseño, verificación, visualización de la información e inclusión social a través del lenguaje.

El servicio audiovisual público como memoria y patrimonio documental centra la tercera aportación del libro. Mercedes Caridad Sebastián, Sara Martínez Cardama, Fátima García López y Ana María Morales García comparan las estructuras de conservación de Reino Unido, Francia, Holanda y España y revisan las principales normativas y regulaciones a nivel internacional y europeo que lo configuran como memoria colectiva y le garantizan especial protección.

En el cuarto capítulo, Francisco Campos analiza la perspectiva del servicio audiovisual público o de los medios de servicio público audiovisual en el actual ecosistema digital de acceso a la información y comunicación y se detiene en las estrategias y tendencias de regulación, gobernanza y financiación de la radiotelevisión pública en Europa ante la tercera década del siglo XXI, en la que los flujos de la comunicación audiovisual son cada vez más discontinuos, desprogramados, fragmentados y accesibles a través de diversas formas y plataformas.

José Rúas-Araújo, José Fernández-Holgado y José Ángel Alén-Amil describen en el quinto capítulo del libro la regulación de los procesos electorales y debates televisados por las distintas entidades y organismos reguladores de las televisiones públicas en Europa, con especial referencia al OFCOM del Reino Unido, como modelo y servicio a seguir. En sus conclusiones, los autores argumentan la urgencia de profundizar en la regulación audiovisual y las garantías 
democráticas de los distintos procesos electorales y debates celebrados en España.

En un contexto de cambios e incremento de la competencia, la reputación se convierte en una importante aliada para salir victoriosa de la batalla de la credibilidad, de la referencialidad y de la confianza. Pero sin confianza, no hay reputación. Como apunta en el capítulo seis la profesora Carmen Costa-Sánchez al analizar RTVE, el círculo es eterno y la gestión reputacional, a falta de un análisis de documentos internos de planificación y estrategia, semeja más reactiva que proactiva.

El séptimo capítulo ofrece un estudio de Sara Pérez-Seijo y María José Benítez de Gracia sobre la implementación de narrativas inmersivas en el que se afirma que la Unión Europea de Radiodifusión ha incentivado su experimentación y aplicación entre sus miembros y se explica cómo France Télévisions, Radiotelevisión Española o Radio Télévision Belge de la Communauté Française ejemplifican esa apuesta.

Ana María López-Cepeda ofrece en el capítulo ocho una panorámica de la regulación legal sobre participación en las televisiones públicas de la UE y analiza los principales mecanismos previstos legalmente relacionados con la participación institucionalizada y con la participación a través de los medios de comunicación.

María-Magdalena Rodríguez-Fernández y Eva Sánchez-Amboage presentan en el capítulo nueve los resultados de su estudio de monitorización de las radiotelevisiones públicas de España y Portugal en Facebook para identificar los acontecimientos que han impactado en sus usuarios y conocer sus reacciones. El libro se cierra con la identificación de modelos y tendencias de la radiotelevisión pública regional europea que Marta Rodríguez-Castro y Mónica López-Golán identifican con ejemplos de descentralización y de pérdida de autonomía.

El libro se enmarca en las acciones de fusión del proyecto CSO201566543P-MINECO-FEDER ("Indicadores de gobernanza, financiación, rendición de cuentas, innovación, calidad y servicio público de las RTV europeas aplicables a España en el contexto digital" del Programa estatal de Fomento de la Investigación Cientifica y Técnica de Excelencia, subprograma estatal de Generación de Conocimiento del Ministerio de Economía y Competitividad de 
España, cofinanciado por el Fondo Europeo de Desarrollo Regional (FEDER) de la Unión Europea) en un momento en que el la estrategia para estar la nube es una transformación radical que lideran las corporaciones públicas de los países más al norte de Europa motivadas porque la práctica totalidad de la población a la que se dirigen tiene acceso a Internet, por la fuerte penetración de las competidoras plataformas globales de los GAFAN (Google, Amazon, Facebook, Apple y Netflix) y por la necesidad de reconectarse con las audiencias jóvenes, que son las que están más alejadas del servicio audiovisual público y, a la vez, el target prioritario de los nuevos servicios y difusión gratuita y de pago en la red..

Ante la migración social y tecnológica a internet, la primera reacción de los operadores públicos fue crear plataformas de integración de los contenidos difundidos por los sistemas tradicionales. Las principales plataformas en línea de las corporaciones públicas europeas de radiotelevisión son generalistas y se estructuran en torno a una bome desde donde se puede acceder a su mejor oferta televisiva y radiofónica. Además, permiten seguir en directo los contenidos de los diferentes canales con opción, en caso de exigir registro, de personalizarlos a demanda según los intereses del usuario.

El segundo paso ha sido avanzar en la especialización y diferenciación. Algunos entes públicos refuerzan su oferta con webs temáticas propias dirigidas a públicos más jóvenes con tendencia al consumo televisivo en Internet. Estas propuestas, que presentan multitud de opciones, responden a una navegación segura, entretenida y, en muchos casos, educativa. No obstante, el análisis de la estructura de las plataformas revela todavía poco enfoque temático y de especialización. Se detecta más una estrategia de integración que de orientación autónoma a públicos específicos, tratando de cumplir al mismo tiempo con la misión de servicio público, salvo en algunas corporaciones más enfocadas (France TV, BBC, RTE y VRT).

El tercer paso parece ir en el sentido de esa última tendencia, es decir, hallar una estrategia autónoma de orientación propia para las plataformas digitales como prioridad de la producción y la distribución. Pero todo ello combinándolo a través de plataformas propias y ajenas, tanto en las de vídeo generalista (tipo YouTube) o tematizado (Netflix, Dailymotion) como en las de redes sociales (Facebook, Instagram, etc.). 
El panorama actual en el que se contextualiza este libro permite clasificar las radiotelevisiones públicas europeas en tres categorías: a) aquellas corporaciones (países escandinavos y del centro de Europa, Bélgica y Holanda) que se orientan ya a Internet en primer lugar; b) organizaciones que avanzan en la transformación digital sosteniendo los medios tradicionales (Alemania, Reino Unido o Francia); y c) empresas con predominio de los medios tradicionales que mantienen la digitalización como un sistema de difusión alternativo, complementario y todavía secundario.

\section{Bibliografía}

BBC (2018). BBC Annual Plan for 2018/19. Acceso:

https://www.bbc.co.uk/aboutthebbc/insidethebbc/howwewor k/reports/annual plan 2018.

Observatorio Audiovisual Europeo. Acceso:

https://www.obs.coe.int/en/web/observatoire/.

CdE (2009). Recommendation 1878/2009. The funding of Public Service Broadcasting.

Acceso: http://assembly.coe.int/nw/xml/XRef/Xref-XML2HTMLen.asp?fileid $=17763$ \&lang $=$ en.

CdeE (2018). Public Service Media. Acceso:

https://rm.coe.int/leaflet-public-service-media-en/1680735c27.

CdeE (2012). Recommendation CM/Rec(2012) of the Committee of Ministers to member States on Public Service Media Governance (Adopted by the Committee of Ministers on 15 February 2012 at the 1134th meeting of the Ministers' Deputies). En:

https://search.coe.int/cm/Pages/result details.aspx?ObjectID $=09000016805 \mathrm{cb} 4 \mathrm{~b} 4$

EAO (2018). Television, VOD, cinema and video in 40 European States: markets and players, services and usage. Acceso: http://yearbook.obs.coe.int/.

EBU (2016). PSM in the 21St Century: What Value and Which Values? Media Intelligence Service. www.ebu.ch/mis. 
EBU (2018). Audience Trends Television 2018. Media Intelligence Service. www.ebu.ch/mis.

EBU (2018). Audience Trends Radio 2018. Media Intelligence Service. www.ebu.ch/mis.

META-MÉDIA (2018). Europe: l'audiovisuel public en transformation, les nordiques en avance https://www.metamedia.fr/2018/03/22/europe-laudiovisuel-public-entransformation-les-nordiques-en-avance.html.

OFCOM (2018). Revealling Reality. Scrolling news: The changing face online news consumption. www.ofcom.org.uk.

OFCOM (2018a). News Consumption in the UK: 2018. Acceso: https://www.ofcom.org.uk/research-and-data/tv-radio-andon-demand/news-media/news-consumption.

Osterwalder, A. (2004). The business model ontology. A proposition in a design science approach. Tesis presentada en Ecole des Hautes Etudes Commerciales de l'Université de Lausanne.

Parker, G.G., Van Alstyne, M.W., Choudary, S.P. (2016). Platform Revolution: How Networked Markets Are Transforming the Economy and How to Make Them Work for You Hardcover. N. York: Norton Co.

Tiwana, A. (2013). Platform Ecosystems. Aligning Architecture, Governance and Strategy. Morkan Kaufmann.

\section{Miguel Túñez-López \\ Francisco Campos-Freire \\ Universidade de Santiago de Compostela}

PARA CITAR: Túñez-López, M. y Campos-Freire, F. (2018). "La innovación digital y la renovación 3P: públicos, plataformas y programas". En Pérez-Seijo, S., Rodríguez-Castro, M. y Túñez-López, M. (Eds.), Debates sobre valores e indicadores del servicio audiovisual público en Europa (pp. 9-16). Cuadernos Artesanos de Comunicación, cac142. La Laguna (Tenerife): Latina. DOI: 10.4185/cac142. 


\title{
Acciones de innovación de las radiotelevisiones públicas europeas
}

\author{
Valentín-Alejandro Martínez-Fernández \\ Universidad de A Coruña \\ Óscar Juanatey-Boga \\ Universidad de A Coruña \\ Verónica Crespo-Pereira \\ Pontificia Universidad Católica del Ecuador Sede Ibarra
}

PARA CITAR: Martínez-Fernández, V-A.., Juanatey-Boga, Ó. y Crespo-Pereira, V. (2018). "Acciones de innovación de las radiotelevisiones públicas europeas". En Pérez-Seijo, S., Rodríguez-Castro, M. y Túñez-López, M. (Eds.), Debates sobre valores e indicadores del servicio audiovisual público en Europa (pp. 17-31). Cuadernos Artesanos de Comunicación, cac142. La Laguna (Tenerife): Latina. DOI: $10.4185 / \operatorname{cac} 142$

\section{Resumen}

La profunda revolución mediática de las últimas décadas ha impuesto nuevas fórmulas en el desarrollo de todos los procesos de la actividad televisiva. Innovar se ha convertido en una demanda intrínseca a la gestión de las televisiones públicas de todo el mundo. La innovación, concebida transversalmente, constituye un pilar esencial para el sostenimiento del sistema público al facilitar modelos estratégicos y operativos encaminados a la eficiencia económica, tecnológica y optimización de demandas sociales que evidencian la vigencia y utilidad social de los servicios prestados por la televisión pública. El actual modelo de negocio de los broadcasters públicos responde a unas claves tendentes hacia la integración, la transparencia, la cooperación 
multilateral, la distribución de contenidos omnipresente y la atención altamente personalizada y segmentada de los diferentes públicos que conforman la audiencia.

Palabras clave: televisión pública, innovación, contenidos, distribución, Europa.

\section{Introducción}

La transformación digital, propiciada por los desarrollos de las tecnologías de la información y la comunicación, ha significado fundamentalmente un importante cambio en el comportamiento del consumidor de contenidos informativos $y$ de entretenimiento. Consecuentemente, en la adaptación a las nuevas demandas, la innovación desempeña un papel esencial tanto en la optimización de la respuesta a los cambios en los hábitos de consumo como en la anticipación a los mismos mediante análisis predictivos.

De modo que innovar trasciende al concepto de sobrevivir, pues supone también abrir nuevos campos de relación con los consumidores al objeto de establecer vínculos de sostenibilidad e implicación activa.

En este sentido y en el ámbito de la comunicación social, los medios denominados convencionales son los que han experimentado un mayor impacto, toda vez que las tecnologías abocan no sólo a la creación de plataformas de distribución de contenidos y nuevos formatos de los mismos sino también a la formulación de propuestas que conlleven modelos de negocio propios de la economía de la atención, donde el engagement desempeña un rol básico. Lo esencial no es ya la facilidad de acceso al medio, lo nuclear reside en la captación de la atención del consumidor para obtener de éste el mayor tiempo de dedicación.

En el caso concreto de la televisión, desde el final de la década de los noventa del pasado siglo, los cambios adaptativos al nuevo escenario mediático han sido constantes, en muchas ocasiones erráticos y casi siempre reactivos ante la aparición de nuevas propuestas de consumo de productos audiovisuales. Un escenario, por tanto, complejo y complicado, donde el modelo público presenta singulares dificultades 
adaptativas por su propia naturaleza sustentada en el concepto de servicio.

\section{El entorno de la televisión}

A la hora de analizar el proceso evolutivo de la televisión como medio han de considerarse tres elementos o fuerzas esenciales: a) el marco legal; b) los desarrollos de carácter tecnológico; y, c) la financiación (Prado y Fernández, 2006: 51). Determinantes que, en sí mismos, muestran un sensible perfil contingente al estar sometidos a un entorno con una alta volatilidad desde el punto de vista de las aceleradas transformaciones sociales, políticas y tecnológicas que, a su vez, exigen una permanente adaptabilidad a los cambios que implican la concepción de nuevos modelos estructurales.

Así, bajo esta perspectiva, cabe entender el profundo proceso de concentración experimentado por el sector de la televisión en los albores del presente siglo pero que, sin embargo, no pudo frenar el movimiento descentralizador (Moragas y Prado, 2001: 4) imperante en la actualidad, impulsado en virtud de la aparición de nuevos modelos de competencia y sistemas de distribución como, por ejemplo, el IPTV o el TDT.

Ahora bien, todos estos cambios orbitan entorno a una audiencia cuyos hábitos de consumo gozan de una gran capacidad de adaptación a los mismos y en ella misma reside su causa (Rodríguez, Martínez y Juanatey, 2005: 46). Es decir, desempeña el papel capital, pues todo se produce en función de ella. Además, no ha de obviarse, la capacidad proactiva dada a la misma por los avances tecnológicos; por consiguiente, la audiencia se ha convertido en un agente activo no sólo de consumo de contenidos televisivos sino también generador, en cierto modo, de los mismos al disponer de la posibilidad de interactuar y convertir a esa interactuación en una parte esencial del producto. Un producto que conlleva en su consumo una carga emocional (Crespo, Martínez y García, 2016: 211).

El telespectador no es ya una figura pasiva ante una pantalla al tener la capacidad de adoptar el rol de produsuario (Bruns, 2014: 86), se ha erigido en un consumidor-productor activo cuya intensidad de acción cabe ser graduada por aquel (López, Negreira y Rodríguez, 2016: 62). 
Ante este nuevo y agitado escenario mediático, reflejo de un ecosistema en constante evolución, ya en lo relativo a la televisión pública europea, Campos (2013:3176 y ss.) llama la atención respecto a la necesidad de efectuar una profunda revisión y adaptación de la cultura corporativa, junto a las lógicas de gestión, creación, producción y distribución de contenidos por parte de las correspondientes corporaciones, al objeto de efectuar un detallado y riguroso análisis de todas aquellas características que les son consustanciales y constituyen su razón de ser como elementos fundamentales de servicio público, cuya solidez ha comenzado a hacerse líquida en el ámbito de un contexto agitado por una crisis financiera, potenciada por una corriente orientada a vulnerar su legitimidad como operadora desde la esfera pública, al cuestionarse los principios de su misión fundacional.

Una crítica amparada, en gran medida, por el argumento de la obsolescencia de un modelo de gestión que no conecta con la realidad social y por ende se hace prescindible en un marco de restricción económica donde se ha de priorizar la aplicación de recursos públicos.

Por su parte, la Unión Europea también incide en la conveniencia de llevar a cabo una revisión del desempeño de lo público en el ámbito mediático; de ahí que en la directiva 2010/13/UE se inste a una remodelación estructural, tecnológica y financiera de los medios públicos y entre los cuales la televisión ocupa un lugar predominante. Ante esto, cabe una visión de largo alcance al concebir a los denominados fenómenos de convergencia y digitalización no como una amenaza sino una oportunidad, toda vez que ofrece la evolución del servicio público como broadcaster (PSB) a la explotación de la comunicación multimedia (PSM), tal y como precisan Larrondo et al (2016: 290), al tiempo de poder plantear una oferta de consumos híbridos.

\section{La innovación como clave de adaptación}

Situados en este contexto, la innovación, entendida desde su concepción transversal aplicada a todo el espectro de actuación mediática, se antoja como un recurso relevante para dar lugar a nuevos modelos estratégicos y operativos que permitan la eficiencia en su incardinación en la realidad económica y tecnológica para, de esta manera, lograr una óptima adaptación a las nuevas demandas sociales 
y encontrar en ellas nuevos cauces que evidencien la vigencia de la función de servicio prestada por la televisión pública y su contribución al fortalecimiento del sistema democrático.

No obstante, la innovación tiene sentido si va dotada del atributo de la sostenibilidad. Consecuentemente, el nuevo modelo de negocio a desempeñar por la televisión pública ha de ser concebido desde la integración, la transparencia, la cooperación multilateral, la generación de circuitos de retroalimentación en la comunicación y una visión integral de la atención a los públicos conformadores de la audiencia y mediante el aprovechamiento de la potencialidad de las tecnologías.

Ciertamente, este modelo conlleva la creación e implementación de otros centrados en la producción, distribución y consumo, al igual de generar uno específico para el análisis permanente de la audiencia y que dé la posibilidad de establecer criterios basados en el enfoque predictivo, pues ello redundará en lo que Sundet (2016:20) llama comprensión de las audiencias actuales y susceptibles de ser analizadas desde diferentes campos de visión y de los cuales el más novedoso, pero con un gran desarrollo, es el neuromarketing (Crespo, Martínez y Campos, 2017: 14).

De acuerdo con Carvajal et al (2015: 19), en el estudio de la innovación aplicada a las televisiones públicas se debe de considerar cuatro áreas básicas: 1) producto/servicio; 2) estructura organizativa; 3) producción-distribución; y 4) marketing.

En la producción de contenidos es donde la televisión pública cuenta con una importante ventaja competitiva, al no estar sometida al criterio de la rentabilidad y dado que ésta no siempre responde al interés general de la audiencia y mucho menos al concepto de la calidad. En esta idea abunda Camacho (2005: 31) al estimar que dicha producción ha de sustentarse en el modelo clásico compuesto por los objetivos de informar, formar y entretener, pues en ellos reside la clave para fortalecer el posicionamiento y competitividad de las televisiones de gestión pública respecto a aquellas ofertas dirigidas comercialmente al entretenimiento. En línea con esto se coloca la Carta Real 2017-27 de la British Broadcasting Corporation (BBC), en la cual se otorga un papel preponderante a la elaboración de contenidos innovadores, de 
calidad y con una clara orientación hacia el servicio público (Departament for Culture, Media \& Sport, 2016: 12).

No solo es la BBC, en el marco de las televisiones públicas europeas, quien realiza un esfuerzo importante en llevar a cabo acciones de innovación en la producción de sus contenidos. También han de considerarse, a modo de ejemplos, a la televisión de Lituania, Latvijas Televizijam (LTV), en su apuesta por la calidad en los servicios informativos, así como a la Cyprus Bradcasting Corporation ( $\mathrm{CyBC}$ ); la irlandesa Raidió Teilifís Éireann (RTÉ) o la danesa Danmarks Radio.

La innovación en los productos informativos constituye, no solamente desde el plano de la tecnología sino también de la formulación de nuevos formatos y modos de interacción con la audiencia, uno de los elementos explicativos de la nueva reformulación del servicio público. Una visión de innovación que abarca algo tan esencial como el establecimiento de marcos de colaboración entre las diferentes corporaciones públicas europeas y compañías tecnológicas y cuyos resultados se plasman ya en la creación e implementación de nuevos desarrollos tecnológicos como pueden ser los casos de TelegramBot y VR Journalism.

En definitiva, las televisiones públicas europeas muestran una tendencia a dotar a sus contenidos informativos de un valor sustentando en el interés general de sus audiencias, concebidas con una visión global, al objeto de consolidar su posicionamiento de liderazgo ante determinados públicos o bien abrirse a nuevos segmentos que no encuentran respuesta a sus demandas en los canales de televisión comerciales.

\section{Innovación de contenidos}

Uno de los aspectos llamativos del análisis de la innovación de contenidos por parte de las televisiones públicas europeas se sitúa en la acentuada orientación dada hacia los aspectos educativos, donde sus portales web y desarrollo e implementación de apps desempeñan un papel protagónico.

A este respecto, destacan Radiotelevisión Española (RTVE), France Télévisions y la BBC, como impulsoras de propuestas de carácter educativo centradas en la interactividad y con una segmentación basada 
en los públicos, materias y grados de conocimiento y que tienen por objetivo captar a telespectadores de todas las edades y a través de diferentes soportes y pantallas.

Igualmente, en el campo educativo, han de señalarse experiencias puestas en marcha por la $\mathrm{BBC}$, mediante el canal digital CBeebies, orientado a un público de hasta seis años; la BBC Live Lessons dirigido a escolares de primaria y secundaria. También cabe señalar a la RTBF de Bélgica en su propuesta de cooperación con otras instituciones públicas dirigidas a impulsar la educación en los medios de comunicación social.

Con estas iniciativas se busca crear un engagement con un amplio abanico de públicos y gracias a una serie de plataformas y productos que no cuentan con competencia en las televisiones comerciales, al tiempo de dar sentido a la vocación de servicio público inherente a su misión fundacional. De esta forma, la innovación resulta primordial en la adaptación a las nuevas demandas sociales.

En la búsqueda de nuevos públicos, de nuevas audiencias, ha de entenderse el esfuerzo de las televisiones públicas por innovar en virtud de formatos novedosos centrados en el entretenimiento y un terreno en el cual, en el transcurso de los últimos años, su posicionamiento había cedido sensiblemente a favor de los canales comerciales, principalmente en el segmento que corresponde a los públicos infantiles y juveniles. Para ello, las plataformas digitales y la interacción de contenidos de marcado acento innovador se erigen como el medio más pertinente para captar públicos de los mencionados perfiles y para los cuales se producen contenidos a su medida, en respuesta concreta a sus demandas y gracias a la aplicación de estrategias transmedia. En este tipo de propuestas vuelven a destacar la BBC, RTVE y France Télévisions.

En términos generales cabe subrayar que una gran parte de las televisiones públicas europeas, en mayor o menor medida, cuentan con proyectos tendentes a encontrar novedosas fórmulas narrativas dirigidas al campo del entretenimiento. Bajo esta premisa, se identifican las iniciativas de la RTBF de Bélgica a través de la Webcréation, un lugar digital pensado para llevar a cabo la experimentación de producciones de tipo interactivo para dar soporte a la producción de 
webseries y webdocs con vocación para llegar a una audiencia compuesta por públicos jóvenes.

A este planteamiento, pero con una visión más amplia en la segmentación de la audiencia, responden las propuestas de RTVE orientadas a producciones que abordan, desde la ficción, el género histórico.

Los desarrollos tecnológicos han facilitado la globalidad, pero igualmente la microsegmentación, la atención a pequeñas audiencias que la propia atomización del sector audiovisual ha generado.

\section{Construir la audiencia con audiencias}

En el momento actual, lo relevante no es llegar a una gran audiencia sino construir esa gran audiencia a través de otras más pequeñas y que sin la tecnología sería casi una utopía alcanzar.

Con este objetivo marco, las televisiones públicas han puesto en marcha estrategias que tratan de dar respuesta eficiente a demandas de contenidos planteadas por pequeños grupos de públicos y que se integran temáticamente.

Un aspecto relevante en el análisis de la capacidad de innovación mostrada por las televisiones públicas europeas responde a la actuación de la misma en el seno de las estructuras de tipo organizativo. Unas estructuras que en el ocaso del pasado siglo mostraban una cierta esclerosis y conducían al aislamiento de la sociedad que les daba razón de ser.

En el estudio de las tendencias en la innovación de los modelos de gestión de las corporaciones públicas llama la atención la creciente proclividad a la generación e impulso de centros o departamentos destinados a trabajar de modo focal en la creación y desarrollo de productos y servicios que eficientemente se adapten a los deseos de los diferentes públicos a los cuales ha de atenderse.

La labor de estos departamentos, algunos de ellos concebidos a modo de laboratorios experimentales, pone singular énfasis en la plasmación de novedosas propuestas narrativas y la optimización de la distribución, con una especial atención hacia los públicos jóvenes. De entre estas iniciativas cabe destacar el laboratorio de France Télévisions Nouvelles Écritures y Transmedia. 


\section{Efecto legitimador de la transparencia}

Una de las críticas comunes a las televisiones públicas, por parte de quienes cuestionan su razón de ser en el seno de una sociedad como la actual, consiste en la opacidad de su gestión y la impermeabilización hacia cualquier escrutinio externo del desempeño de sus órganos de gobierno, todo ello con una clara incidencia en su credibilidad como medio (Calvo, Martínez y Juanatey, 2014: 302).

Consecuentemente, en aras a lograr una sintonía con los tiempos actuales y en los cuales el sometimiento a la fiscalización de las instituciones representativas de los intereses ciudadanos es una exigencia incuestionable en un espacio democrático, la transparencia se ha convertido en una de las banderas de mayor visibilidad de las corporaciones.

No puede obviarse que, al respecto, la exhaustiva rendición de cuentas supone un excelente instrumento legitimador del buen hacer y exponente de los valores que han de primar en la gestión de toda corporación pública.

Consecuentemente, la Unión Europea de Radiodifusión (UER) en su informe correspondiente al año 2014 ya estableció todo un corolario de indicadores inherentes a la percepción y medición de la transparencia en el seno de los entes de gestión pública y que cabe sintetizar en: a) guías editoriales; b) guías editoriales para redes sociales; c) transparencia financiera; d) documentación relativa a costes varios tales como eventos, adquisición de derechos o salarios; e) documentos relativos a la misión, visión y principios básicos de la corporación; f) existencia de comités de quejas y marco de su funcionamiento; g) representación de la corporación en entes como consejos de prensa nacional o instituciones de orden similar; $\mathrm{y}, \mathrm{h}$ ) plataformas de difusión de la información, así como grado de calidad de las prácticas en transparencia.

Sin embargo, en el marco europeo, puede apreciarse una sensible distorsión y por ende falta de homogeneidad en el análisis comparativo de todas aquellas informaciones facilitadas a iniciativa propia por las corporaciones públicas que rigen las televisiones. Por consiguiente, a pesar de que la transparencia es capital para las corporaciones, no existen condiciones para plantear la existencia de tendencias definidas 
y posicionamientos armónicos, pues realmente solo se identifican casos específicos que reflejan un mayor o menor acierto en la forma de aplicar la transparencia.

Una vez más, también en la forma de concebir la innovación aplicada a la transparencia, la BBC marca pautas de actuación, seguidas entre otras televisiones públicas por la finlandesa Yle y la irlandesa RTÉ.

\section{Impacto de la innovación en la comercialización y distribución}

Otras de las acciones de innovación efectuadas por las televisiones públicas europeas se identifican con las fórmulas de comercialización y que vienen determinadas por la globalidad del mercado, una oportunidad para mejorar tanto la presencia fuera del llamado ámbito natural o propio como en orden a incrementar la cuenta de ingresos en virtud de productos dotados de un amplio espectro de consumo sociogeográfico; un impacto económico favorable que da lugar a la mejora de los resultados y con ello incidir en la reinversión en nuevos productos.

No ha de olvidarse que, por otra parte, las televisiones públicas son un elemento sumamente relevante en la conformación y percepción de sus respectivas marcas país, de modo que con la internacionalización de sus productos no ha de verse nada más el aspecto tangible, pues la intangibilidad goza también de un importante valor estratégico.

De acuerdo con esta visión de los mercados, la comercialización no es un tema baladí en la concepción de la innovación, toda vez que ya no se trata únicamente de llegar a una audiencia, se persigue posicionarse en esa audiencia y lograr que sus integrantes desarrollen un engagement que vaya más allá del mero consumo de unos contenidos o incluso la fidelización a la marca, al canal de televisión, pues lo significativo reside en conseguir una proactividad en la prescripción del mismo y en la conformación de una imagen positiva.

En razón a ello, las corporaciones públicas llevan a cabo grandes esfuerzos tendentes a innovar en los canales de distribución y comercialización, con el fin de generar un consumo múltiple a través de las diferentes plataformas y establecer un sistema de consumo continuo, pues innovar significa también encontrar medios para 
optimizar el ciclo de vida de los contenidos y con ello propiciar nuevas fuentes de beneficios tangibles e intangibles.

Una de las formas de conseguir dicha optimización es gracias a la formulación de acuerdos comerciales entre las corporaciones. Este, por ejemplo, es el caso de la compañía sueca TG4 y la BBC. Estos convenios facilitan dos modelos de gestión; por un lado, el de aquellas que se centran en la producción propia y venta de sus producciones a terceros, y por otro, el de quienes se nutren básicamente de contenidos producidos por otros y de este modo reducen su estructura a los efectos de optimizar sus resultados económicos.

Del estudio de las acciones innovadoras de internacionalización de la comercialización de las producciones de contenidos realizadas por las televisiones públicas europeas ha de colegirse que no existe tampoco una tendencia claramente definida y con elementos comunes, si bien destaca el modelo aplicado por la DR de Dinamarca.

Una parte sustancial de la comercialización reside en la distribución. Sin una distribución eficiente, no puede entenderse una comercialización adecuada. La distribución es fundamental para lograr un posicionamiento adecuado.

La tendencia de las corporaciones públicas en la orientación de la innovación aplicada a la distribución se relaciona con la disposición de sistemas tecnológicos facilitadores de una presencia constante o distribución de tipo omnipresente; la producción de formatos capaces de ser consumidos mediante pantallas múltiples, así como las dirigidas al consumo en Smart TV y HbbTV. Igualmente ha de significarse una sensible inclinación a la determinación de acciones innovadoras que contribuyan a conseguir un mayor rendimiento de la televisión digital, al igual que a la producción y emisión en HD y 4K, junto con los avances en la producción y consumo basado en la realidad virtual y vídeos 360 .

El desarrollo de las tecnologías de la información y la comunicación ha dado lugar a un nuevo modelo de comunicación canalizado a través de las redes sociales y en el cual la acción interactiva de los sujetos que intervienen en las mismas resulta esencial (Campos et al, 2016: 451).

Hoy en día todo está y fluye en las redes, todo se propaga a través de ellas y no estar en las mismas significa perder sensiblemente la 
capacidad de visualización. Así, estar significa ser (Martínez et al, 2015: 46).

Las redes sociales se han hecho idóneas para una efectiva comunicación horizontal. Por tanto, sin entrar en el grado de uso de las mismas, el valor de las mismas en el denominado ecosistema digital y público es múltiple al transformarse en un excelente instrumento de marketing para alcanzar una óptima interacción con los públicos, facilitar una adecuada retroalimentación, visualizar y catalizar las acciones de transparencia, lograr engagement, sentido de pertenencia a una comunidad, así como crear y potenciar el valor de marca (Bertot, Jaeger y Hansen, 2012: 32).

En consecuencia, la gran mayoría que conforman las televisiones públicas europeas destinan una parte significativa de su esfuerzo innovador a determinar acciones susceptibles de ser trasladadas a su presencia en las redes sociales. Una presencia que principalmente se identifica en la relación interactiva con su audiencia y la promoción de sus producciones, así como en la propagación de informaciones o contenidos que generen notoriedad.

Igualmente, para algunas corporaciones, las redes se convierten en un excelente banco de pruebas para rodar algunos de sus formatos experimentales y la implementación de acciones propiamente innovadoras y que necesitan de una cierta contrastación mediante la aplicación de modelos básicos o prototipos.

\section{A modo de coda}

La innovación no ha de entenderse ya como algo emergente en la gestión de las televisiones públicas.

En los últimos años ha cobrado carta de naturaleza propia y forma parte del aspecto cotidiano de la gestión.

Innovar no es subirse a la ola de una moda, constituye algo necesario para comprender la gestión, pero no existe innovación si esta no llega a sus destinatarios y ellos la hacen suya al incorporarla a su quehacer común como elementos constitutivos de la audiencia.

En las turbulencias propias de un entorno sometido a profundas transformaciones por el efecto de los desarrollos tecnológicos, la innovación desempeña un rol capital como amortiguador $y$ 
neutralizador de los efectos negativos del cambio, al permitir la adaptación a los nuevos escenarios.

Desde la óptica de las televisiones públicas, la innovación constituye una de las claves de bóveda para sostener su esencialidad en la sociedad actual.

\section{Bibliografía}

Bertot, J.C., Jaeger, P.T. y Hansen, D. (2012). The impact of policies on governmet social media usage: Issues, challenges and recomendatios. Government Information Quarterly, 29 (1) 30-40.

Bruns, A. (2014). Beyond the Producer/Consumer Divide: Key Principles of Produsage and Opportunities for Innovation. En Peters, M.A., Besley, T. y Araya, D. (Eds.), The New Development Paradigm: Education, Knowledge Economy and Digital Futures. New York: Peter Lang.

Calvo-Porral, C., Martínez-Fernández, V.A. y Juanatey-Boga, O. (2014). La credibilidad de los medios de Comunicación de masas: una aproximación desde el Modelo de Marca Creíble. Intercom-RBCC. V. 37 N. 2 21-49

Camacho, R. (2005). Televisión de calidad: distinción y audiencia. Comunicar, (25), 17-18.

Campos-Freire, F. (2013). Crisis y dilemas de la financiación de TV pública en Europa. En Ledo Andión, M. y Vasallo de Lopes, M.I. XIII Congreso Internacional Ibercom Comunicación, Cultura e Esferas de Poder. Santiago de Compostela: Ibercom

Campos-Freire, F., Rúas-Araújo, J., López-García, X. y MartínezFernández. V.A. (2016). Impacto de las redes sociales en el periodismo. El Profesional de la Información, 25 (3), 449-457.

Carvajal, M., Arias, F., Negredo, S. y Amoedo, A. (2015).

Aproximación metodológica al estudio de la innovación en periodismo. Observatorio (OBS) Journal, 9 (3), 15-31. 
Crespo-Pereira, V., Martínez-Fernández, V.A. y García-Soidán, P. (2016). El profesional del neuromarketing en el sector audiovisual español. El profesional de la información, 25(2), 209-216.

Crespo-Pereira, V., Martínez-Fernández, V.A. y Campos-Freire, F. (2017). La Neurociencia para la innovación de contenidos en la televisión pública europea. Comunicar, 25 (52), 09-18.

Larrondo, A., Domingo, D., Erdal, I.J. y Masip, P. Van den Bulck, H. (2016). A comparative study on Europran public service broadcasting organisations. Journalism studies, 17(3), 277-300

López-García, X., Negreira-Rey, M.C. y Rodríguez-Vázquez, A.I. (2016). Cibermedios hiperlocales ibéricos: el nacimiento de una nueva red de proximidad. Cuadernos.Info, (39), 225-240.

Martínez-Fernández, V.A., Juanatey-Boga, O., Crespo-Pereira, V. y Mahauad-Burneo, M.D. (2015). Prensa nativa digital y redes sociales: cibermedios en Facebook y Twitter. International Journal of Information Systems and Software Engineering for Big Companies, $2(2), 42-50$

Moragas, M y Prado, E. (2001). Repensar la televisión pública en el contexto digital. Barcelona: Consell de L'Audiovisual de Catalunya.

Rodríguez-Campo, L., Martínez-Fernández, V.A. y Juanatey-Boga, O. (2005). Evolución en las preferencias de los consumidores de productos audiovisuales. Comunicar, 25(2).

Prado, E. y Fernández, D. (2006). The role of Public Service Broadcosterns in the era of convergence. A case study of Televisiò de Catalunya. Communications \& Strategies (62), 49-69.

Sundet, V.S. (2016). Still'Desesperately seeking the audience? Audience making in the age of media convergence (the Lilyhammer experience). Northerm Lights: Film \& Media Studies Yerabook, 14 (1), 11-17. 


\subsection{Otros documentos}

Departament for Culture, Media \& Sport (2016). A BBC for the future: a broadcaster of distinction. Recuperado el 15 de abril de 2018, de

https://www.gov.uk/government/uploads/system/uploads/attachm ent data/file/522784/DCMS BBC Charter Review 2016 Summar y.pdf

\section{Reconocimientos de la investigación}

Los resultados de este artículo forman parte de las actividades de investigación promovidas a través del proyecto del Programa estatal de Fomento de la Investigación Científica y Técnica de Excelencia, subprograma estatal de Generación de Conocimiento del Ministerio de Economía y Competitividad de España sobre "Indicadores de gobernanza, financiación, rendición de cuentas, innovación, calidad y servicio público de las RTV europeas aplicables a España en el contexto digital" (Referencia CSO2015-66543-P) así como de la actividad de la Red Internacional de Investigación de Gestión de la Comunicación (REDES 2016 G-1641 XESCOM) apoyada por la Consellería de Cultura, Educación e Ordenación Universitaria de la Xunta de Galicia (referencia ED341D R2016/019). 



\title{
Diseño, verificación, visualización de la información e inclusión social en los libros de estilo de cinco radiotelevisiones públicas de referencia en Europa
}

\author{
Jorge Vázquez-Herrero \\ Ángel Vizoso \\ Xosé López-García \\ Universidade de Santiago de Compostela
}

PARA CITAR: Vázquez-Herrero, J., Vizoso, Á. y López-García, X. (2018). Diseño, verificación, visualización de la información e inclusión social en los libros de estilo de cinco radiotelevisiones públicas de referencia en Europa. En Pérez-Seijo, S., Rodríguez-Castro, M. y Túñez-López, M. (Eds.), Debates sobre valores e indicadores del servicio audiovisual público en Europa (pp. 35-46). Cuadernos Artesanos de Comunicación, cac142. La Laguna (Tenerife): Latina. DOI: $10.4185 /$ cac142

\section{Resumen}

El presente capítulo muestra los resultados de la revisión y análisis de los libros de estilo de cinco radiotelevisiones públicas europeas de referencia. El objetivo de este texto es identificar qué recogen estos documentos con respecto a cuatro ejes del cambio en el marco de la comunicación periodística: diseño, verificación, visualización de la información e inclusión social a través del lenguaje A través de este estudio se busca advertir el nivel de adaptación de los documentos que rigen el estilo de las organizaciones analizadas, ya que estos serán de gran importancia para enfrentarse a algunos de los desafíos de la comunicación en el panorama actual. 
Palabras clave: libros de estilo, visualización, diseño de la información, nuevas narrativas, verificación de la información, lenguaje inclusivo.

\section{Introducción}

Los libros de estilo son, para cualquier medio de comunicación, un eje a partir del cual vertebrar su actividad diaria. En ellos no sólo están presentes conceptos relacionados con el quehacer periodístico y el tratamiento de la información desde la óptica lingüística. Los libros de estilo son también una seña de identidad y creación de imagen de marca para la empresa informativa. Esta capacidad de diferenciación es de vital importancia en un panorama mediático como el actual, fuertemente marcado por la alta competitividad y la abundancia de mensajes.

Radios, televisiones y grupos mediáticos de toda índole cuentan hoy en día con libros de estilo que actualizan y aplican con el objetivo de producir sus informaciones conforme a los mismos criterios. En este capítulo nos proponemos ver la capacidad de adaptación de los libros de estilo de cinco corporaciones de radiodifusión de referencia europea como RTVE, BBC, YLE, ARD y France Télévisions con respecto a cuatro realidades muy propias del contexto informativo actual: el diseño, la verificación, la visualización y la inclusión social.

\section{Nacimiento y evolución de los libros de estilo}

Podemos situar el nacimiento de los libros de estilo en Estados Unidos, ligados al ámbito universitario, inicialmente como una evolución de los manuales de estilo de los servicios de publicaciones y como resultado de la aparición de las escuelas de periodismo a comienzos del siglo XX. Así, entre las primeras muestras de este tipo de documentos podemos encontrar el Deskbook of The School of Journalism elaborado por la Escuela de Periodismo de la Universidad de Missouri en 1910 (Rojas Torrijos, 2011).

Sin embargo, la popularización de los libros de estilo llegó a partir de su integración en las prácticas de las principales agencias de comunicación - fundamentalmente las norteamericanas Associated 
Press y United Press International en los años cuarenta- y en medios de prestigio como The New York Times, que en 1962 editó su primer manual de estilo.

Desde su concepción inicial, a los libros de estilo se les atribuye la misión de ser una guía básica que advierta sobre los posibles errores más habituales en el proceso de producción informativa. También se espera de ellos que sirvan para resolver aquellas dudas que puedan surgir con mayor frecuencia (Gómez Font, 2006). Del mismo modo, forman parte de la imagen que proyecta la empresa informativa, alimentando su identidad mediante el uso de un lenguaje correcto y un estilo propio que sirva como distintivo frente a otras opciones (Pérez Tornero, 2009). Son, por tanto, un elemento que contribuye a la creación de una personalidad diferenciada para aquellos medios de comunicación que los ponen en práctica y los emplean (FernándezBeaumont, 1987).

En lo que respecta a sus características, encontramos cómo en el ámbito anglosajón los manuales de estilo están más dirigidos al control lingüístico (Vellón Lahoz, 2013). En cambio, si dirigimos nuestra mirada hacia los manuales en español, su estructura más frecuente es la combinación de preceptos y recomendaciones periodísticas por un lado e idiomáticas y lingüísticas por otro.

En cuanto a su denominación, inicialmente existían diferencias entre los libros de estilo - propios de los medios de comunicación-y los manuales de estilo de las editoriales y sociedades científicas. Sin embargo, en la actualidad observamos cómo ambos términos son empleados indistintamente para referirse a la misma tipología de documento (Martínez de Sousa, 2001). La propia evolución de los libros o manuales de estilo ha llevado a su ampliación en lo que a las cuestiones abordadas se refiere. Así, hoy en día es muy frecuente observar la incorporación de referencias a nuevas realidades vinculadas a los avances tecnológicos o las nuevas narrativas empleadas por los medios. No en vano, la actualización y la vinculación con la realidad que día tras día se cuenta en los medios es una necesidad fundamental para la eficacia de un libro de estilo. 


\section{Adaptación a las nuevas tecnologías y nuevos soportes}

La actualización y revisión de los libros de estilo se realiza como consecuencia de las experiencias, investigaciones y reflexiones de los medios de comunicación, los profesionales que en ellos participan y, cada vez más, de las aportaciones realizadas por la audiencia. En el momento actual, marcado por la popularización de internet y las nuevas tecnologías, la actualización de los libros de estilo está altamente vinculada a los avances que se producen en materia tecnológica.

Desde las primeras muestras de los manuales de estilo, los medios han tratado de adaptar su contenido a la realidad imperante. De este modo, los medios pioneros en la materia modificaban sus libros de estilo cuando advertían importantes cambios en el panorama comunicativo o era necesario adaptarlos a los nuevos productos de la empresa editora.

Con la llegada del nuevo milenio y la extensión del uso de la red los manuales de estilo migraron del soporte físico en papel para estar presentes también en línea. Pero este cambio no resultaba suficiente, pues con la integración de la red de redes en el día a día de la producción periodística surgieron toda una serie de nuevas prácticas encaminadas a la producción digital de la información (Boczkowski, 2009). Para dar respuesta a las necesidades del nuevo panorama descrito, en los primeros años del tercer milenio aparecieron los primeros manuales para los cibermedios (Tejedor, Larrondo, Forga y Giraldo, 2008).

En lo que respecta a la presencia de los manuales de estilo en las radiotelevisiones públicas, estos son un instrumento cada vez más accesible para el conjunto de sus usuarios. De este modo, encontramos cómo medios públicos internacionales de contrastado prestigio hacen público su libro de estilo en sus espacios en línea. Sin embargo, en lo que al formato de los mismos se refiere, los documentos relativos al estilo de las empresas informativas permanecen todavía íntimamente ligados al soporte físico en papel. Así, observamos cómo son muchos los textos que se presentan como documentos para descarga en formato PDF, manteniendo las características formales de un libro.

Con todo, es posible encontrar ejemplos de renovación en el formato de los libros de estilo. A este respecto, el ejemplo más claro podría ser 
el manual de estilo de la Corporación de Radio y Televisión Española, accesible a través de su página web. Aunque contiene solamente elementos textuales dispuestos a lo largo de diferentes epígrafes, supone un avance con respecto a algunos de los documentos que se revisan en este capítulo, pues permite la navegación a través de los mismos. De cara a los próximos años, será interesante observar la posible evolución de los manuales de estilo con el objetivo de apreciar si se produce una renovación estilística y de contenido o simplemente son ampliados y adaptados a las nuevas realidades de la comunicación manteniendo su concepción actual.

\section{Tratamiento del diseño, la verificación, la visualización y la inclusión social en los libros de estilo analizados}

Como se ha indicado anteriormente, para la realización de este análisis comparativo se han consultado los libros de estilo de la Corporación de Radio y Televisión Española (RTVE, España), British Broadcasting Corporation (BBC, Reino Unido), Yleisradio (YLE, Finlandia), Arbeitsgemeinschaft der öffentlich-rechtlichen Rundfunkanstalten der Bundesrepublik Deutschland (ARD, Alemania) y France Télévisions (Francia).

RTVE, BBC y France Télévisions cuentan con documentos de estilo agrupados denominados "Manual de estilo" (RTVE, 2017), "BBC News Style Guide" (BBC, 2017a) y "Charte des Antennes" (France Télévisions, 2011) respectivamente. Sin embargo, en el caso de la radiotelevisión pública finlandesa - YLE_ las directrices sobre la forma de proceder tanto profesional como estilísticamente se encuentran publicadas en torno a seis documentos que abordan diferentes aspectos de la producción periodística. Por tanto, se han tenido en cuenta todos ellos a la hora de buscar su relación con las realidades abordadas en este texto.

La radiodifusión pública alemana constituye un caso particular. La $A R D$ es el resultado de la agrupación de diferentes empresas con sede en uno o varios estados del país. Así pues, la $A R D$ no cuenta con un manual de estilo al uso para el conjunto de entidades que la componen, sino que el control sobre esta materia recae en cada una de las radiodifusoras que la integran. Por ello, se han tomado como ejemplo las "Directrices para los programas y servicios en línea" (BR, 2013) de 
Bayerischer Rundfunk (BR), la radiotelevisión pública de Baviera, ya que la principal cadena nacional de la compañía, Das Erste, no hace público su libro de estilo, solamente unas directrices bianuales que también se han consultado y que se recogerán en el análisis.

\subsection{Diseño}

En lo que respecta al diseño de las informaciones producidas, los libros de estilo y documentos consultados no hacen especial hincapié en este sentido. Así, encontramos que en el caso de la YLE finlandesa no aparece ninguna referencia al diseño de la información, mientras que en la "Charte des Antennes" de France Télévisions solamente se incluyen algunas precisiones sobre la configuración de la información relativa a temas determinados, sin describir sus características formales.

Si nos fijamos en el conjunto de la $A R D$, las directrices aprobadas por la compañía para el período 2017-2018 hacen referencia a la necesidad de adaptar la información publicada a las necesidades de las personas con dificultades visuales, auditivas o cognitivas entre otras (ARD, 2017). Esta idea conlleva, indudablemente, una toma de decisiones relativas al diseño de la información y la accesibilidad de la misma. En el caso de la corporación bávara de radiotelevisión, no se incluyen directrices a respecto del diseño en su documento de pautas para los programas y contenidos en línea.

La $B B C$ incide en tres aspectos formales de sus informaciones. En primer lugar, estarían los titulares, limitados a una extensión de entre 30 y 36 caracteres — de 5 a 7 palabras, aproximadamente—. También se hace referencia al estilo de las citas textuales de protagonistas o documentos. Sobre ellas se especifica qué segmentos se deben elegir, dejando claro que se deben eliminar aquellos elementos superfluos al tiempo que se incluyen las palabras necesarias para que la cita cuente con un completo sentido. En el plano de la selección y redacción de las citas textuales, se incide también en la puntuación de las mismas. Este es, sin duda, un aspecto más próximo al campo ortográfico, pero que conecta directamente con el diseño y la disposición de los elementos dentro de la información. Finalmente, el "BBC News Style Guide" describe cómo han de ser los pies de foto de las imágenes publicadas por la corporación: inferiores a dos líneas, sin punto final y siguiendo 
la disposición de los elementos en la imagen cuando se hace referencia a los mismos.

El manual de estilo de la Corporación de Radio y Televisión Española incluye información relativa al diseño de la información en el apartado dedicado a la producción para medios interactivos. Así, se incluyen las características fundamentales de los textos, imágenes, vídeos u otros elementos de los contenidos publicados en RTVE.es. Del mismo modo, el apartado "4.5. La estructura de la noticia" recoge la forma de las piezas informativas en la página web de la corporación, desde el tamaño idóneo de los párrafos hasta ejemplos de la disposición correcta e incorrecta de las palabras empleadas.

\subsection{Verificación}

La verificación de la información es, sin duda, una de las bases del trabajo periodístico. Para el caso concreto de las cinco entidades analizadas, encontramos que todos los documentos relativos al trabajo en el seno de las mismas hacen referencia a la necesidad de comunicar información veraz y contrastada.

De este modo, encontramos que el manual de estilo de RTVE incluye referencias al cambio en la producción de la información que ha supuesto internet. Hoy en día, los ritmos productivos son notablemente más acelerados que hace unos años algo que, según el ente español, no debe impedir la verificación de los datos a publicar. Esto cobra especial importancia en el caso de materiales obtenidos por vías externas a la empresa como pueden ser las imágenes o vídeos aportados por la audiencia u obtenidos en la red, que también han de ser pertinentemente comprobados.

La British Broadcasting Corporation no incluye referencias a la verificación de la información entre las directrices de su manual de estilo, aunque sí en otros documentos relacionados con la producción del ente como el "BBC Annual Plan for 2017/18" (BBC, 2017b), en el que se reconoce la necesidad de luchar contra las noticias falsas. La veracidad y la precisión es también uno de los cinco principios recogidos entre los valores de la empresa: Independence, accountability, truth and accuracy, the public interest e impartiality (BBC, 2017c).

France Télévisions motiva la importancia de la verificación en el gran desarrollo de internet, las redes sociales y la multiplicación de fuentes 
informativas. Por ello, el ente francés destaca la importancia de tener en cuenta la naturaleza de las fuentes informativas, su procedencia, sus posibles intereses e implicación en la información y su credibilidad. Todo esto como paso previo a incorporar los datos aportados por la misma a la información final. Algo similar sucede con las imágenes, ya que France Télévisions recoge la obligatoriedad de que "toda imagen debe ser verificada antes de ser presentada en antena" (France Télévisions, 2011).

La radiotelevisión finlandesa Yleisradio incluye una única referencia a la verificación en sus "Pautas éticas para actividades y contenidos de los programas" (2017). En este documento se remarca la importancia de incluir solamente fuentes que puedan ser verificadas en las informaciones producidas, apostando en mayor medida por aquellos documentos obtenidos por los periodistas de la propia empresa. Se establece la recomendación de evitar, además, el uso de fuentes anónimas como única fuente de información, salvo que concurran circunstancias extraordinarias que obliguen a su incorporación.

Finalmente, ni en las directrices generales de la $A R D$, ni en las pautas de estilo para los programas de la radiotelevisión de Baviera $B R$ se han encontrado referencias al proceso de verificación de la información y las fuentes.

\subsection{Visualización}

En lo que respecta a la presencia de procedimientos y normas de uso de la visualización de la información en los libros de estilo de las cinco radiotelevisiones europeas analizadas, las referencias en la materia son notablemente escasas. Así, vemos como solamente dos de las corporaciones - RTVE de España e YLE de Finlandia- hacen alguna referencia a este tipo de tratamiento de la información.

El manual de estilo de RTVE es el que desarrolla esta realidad con una mayor extensión, dedicando un párrafo a la "Ética en las construcciones visuales" dentro del apartado "Límites en el tratamiento de los hechos", relativo al conjunto de información producida en la corporación. En él se especifica cómo "la infografía, entendida como toda aplicación informática en diseño gráfico y animación, tiene entre sus funciones facilitar la comprensión de los hechos" (RTVE, 2017). Así, este manual recoge la capacidad de la 
visualización de la información de mejorar la comprensión de los datos por parte de las audiencias.

Yleisradio, en su documento de "Principios periodísticos para las noticias y la actualidad en la YLE" (2018), equipara la visualización de la información a través de los gráficos a otros elementos como el sonido, la imagen y el texto. Respecto a todos ellos, dentro de los principios señalados se incide en que la compañía finesa la emplea de un modo responsable, sin crear imágenes falsas.

Tal y como se ha indicado anteriormente, las otras tres entidades que forman parte del análisis —France Télévisions, $B B C$ y $A R D$ - no incluyen referencias al uso de la visualización de la información en sus manuales o guías de estilo.

\subsection{Inclusión social}

Abordamos en este punto el tema más ampliamente recogido por los manuales de estilo analizados entre las cuatro realidades revisadas. Vemos en este punto qué se dice en los libros de estilo sobre adaptación del lenguaje y los contenidos producidos y el tratamiento de la información relacionada con colectivos minoritarios o en riesgo de exclusión.

El manual de estilo de RTVE garantiza aspectos fundamentales como la representatividad de todos los colectivos y organizaciones, así como la necesidad de cuidar el lenguaje en lo que respecta a asuntos de especial sensibilidad en la sociedad evitando estereotipos. Además, se recoge la voluntad de cuidar el lenguaje en lo relativo a las personas mayores, la infancia y adolescencia, así como la discapacidad y la enfermedad. Todo ello con el objetivo de evitar cualquier tipo de discriminación por cualquier motivo — raza, sexo, religión, etc.Todas estas directrices están contenidas en el quinto apartado del manual que lleva por título "Cuestiones sensibles" (RTVE, 2017), el más extenso del documento, hecho que muestra la importancia que se le concede a este tipo de temas.

Algo similar sucede si prestamos atención a la "BBC News Style Guide". En ella observamos a través de diferentes apartados la forma en la que los periodistas de la corporación británica deben tratar las diferentes condiciones del ser humano en sus informaciones. Así, se destaca cómo el color de la piel de un sujeto ha de ser mencionado 
solamente si es relevante para la comprensión de la noticia, se insta a evitar términos como 'los discapacitados', 'los mudos' o 'los sordos', sustituyéndolos por términos que eviten definir a las personas a través de aquellas enfermedades que puedan padecer. En lo que respecta a la condición sexual de los sujetos y a su raza, encontramos directrices similares a lo expuesto para el color de la piel. Han de evitarse en las informaciones a no ser que sean imprescindibles para su comprensión. El libro de estilo de la $B B C$ identifica con toda claridad aquellos términos que han de ser empleados por sus periodistas para la elaboración de informaciones inclusivas y no lesivas respecto a cualquier procedencia, creencia o condición.

France Télévisions incluye dos apartados en su "Charte des Antennes" relativos al respeto de la persona y la dignidad. En ellos se especifica que cualquier condición de origen, raza, sexo o religión será respetada. La corporación busca, además, respetar la diversidad de la población francesa, intentando crear programas y contar con profesionales que reflejen esta diversidad.

Yleisradio hace hincapié simplemente en la necesidad de proteger a los menores y adolescentes, tanto de los contenidos que se emiten como cuando son protagonistas de los mismos. Se establece para ello una serie de procedimientos destinados a su protección.

La $A R D$, en sus directrices dirigidas al canal Das Erste para los años 2017-2018 incluye la apuesta por la cobertura de contenidos relacionados con personas con discapacidad. Esta voluntad es el resultado de la buena acogida de los Juegos Paralímpicos de 2016 en el canal germano. Del mismo modo, el manual de estilo de la Bayerischer Rundfunk hace referencia a la necesidad de que sus contenidos aboguen por el respeto a las opiniones y creencias religiosas e ideológicas de los demás y la no discriminación.

\section{Conclusiones}

Tras lo expuesto, podemos observar cómo todas las radiotelevisiones analizadas hacen referencia al cuidado del lenguaje, la inclusión social y la no discriminación por motivos de raza, sexo, creencia u otra condición. Sin embargo, las otras tres realidades revisadas muestran una presencia dispar. 
El diseño está presente en tanto que pinceladas de las características formales fundamentales de la información, principalmente en aquella producida para los medios en línea.

La verificación de la información constituye, tras lo visto, una acción necesaria para el correcto seguimiento de lo dispuesto en los libros de estilo de cuatro de las cinco radiotelevisiones analizadas — con excepción de la $A R D$ alemana-. Este tipo de procedimientos son la respuesta al creciente volumen de información y a la persecución del objetivo de trasladarle a la audiencia una información totalmente contrastada y de calidad, optando por fuentes confiables e identificadas.

Por último, la visualización de la información es, de los cuatro aspectos abordados, el que menor presencia muestra en los documentos revisados. En este sentido, RTVE e YLE son las únicas corporaciones que describen - aunque brevemente- el empleo de infografías y otros tipos de gráficos en sus piezas informativas.

En resumen, en el momento actual los libros de estilo consultados no muestran avances significativos en lo que respecta a la inclusión de nociones relativas al diseño y a la visualización de la información. Este tipo de cuestiones son gran importancia para la atracción de los usuarios en entornos tan competitivos como pueden ser las versiones en línea de los medios de comunicación. Debido a la gran cantidad de ofertas informativas disponibles en la actualidad, el diseño de la información ha de resultar atractivo y esto, muchas veces, se consigue a partir del tratamiento gráfico de la información mediante la visualización.

En cambio, mientras que la necesidad de verificación de los contenidos informativos se menciona en tanto que práctica inscrita en el ADN del periodismo, la inclusión social y la integración de todos los individuos a través de los contenidos publicados son los temas más abordados por los libros de estilo, no solamente entre los revisados, sino en general. Así, observamos pues el fuerte contenido ético y dirigido a un correcto proceder por parte de los periodistas. Temas como protección de los menores, la no discriminación por razón alguna - sexo, orientación política, religión, enfermedad, edad, etc.- son recurrentes en los manuales de estilo con el objetivo de que las informaciones publicadas 
por los medios — públicos en este caso- se ajusten a la diversidad imperante en las realidades sociales en las que se inscriben.

De cara a los próximos años, será especialmente interesante observar en qué medida se adaptan los libros de estilo de los medios de comunicación públicos y privados a los nuevos desafíos de la producción de la información. Así, se deberá prestar atención a la inclusión de conceptos como la automatización inteligente de los procesos de producción, el diseño e inclusión de herramientas para la interacción con los usuarios o el refuerzo de las pautas y patrones de publicación de contenidos en las redes sociales -levemente descritos por algunos de los manuales - de cara a sacar el mayor partido de este tipo de herramientas en el marco de la creación de contenidos periodísticos.

\section{Referencias bibliográficas}

Boczkowski, P. J. (2009). Technology, monitoring and imitation in contemporary news work. Communication, Culture \& Critique, 2(1), 39-59. DOI: https://doi.org/10.1111/j.1753-9137.2008.01028.x

Fernández-Beaumont, J. (1987). El lenguaje del periodismo moderno: los libros de estilo en la prensa. Madrid: Sociedad General de Español de Librería.

Gómez Font, A. (2006). El español que se habla en los medios. En Cremades García, R. y Núñez Cabezas, E. A. (coord.), Lectura, escritura y comunicación. Málaga: VG Ediciones (Fundación Alonso Quijano).

Martínez de Sousa, J. (2015). Manual de Estilo de la Lengua Española, $5^{a}$ edición revisada. Gijón: Ediciones Trea.

Pérez Tornero, J. M. (2009). Televisión y libros de estilo. De la identidad normativa a la regulación comunitaria. En Alcoba, S. (coord.), Lengua, comunicación y libros de estilo. Barcelona:

Departamento de Filología Española. Universitat Autònoma de Barcelona.

Rojas Torrijos, J. L. (2011). Libros de estilo y periodismo global en español. Origen, evolución y realidad digital. Valencia: Tirant Lo Blanch. 
Tejedor Calvo, S., Larrondo Ureta, A., Forga Martel, M., y Giraldo Luque, S. (2008). Los libros de estilo en el ciberperiodismo de la Web 2.0. Tercer Milenio, 15, año 13. Recuperado el 15 de mayo de 2015, de

https://santiagogiraldoluque.files.wordpress.com/2012/11/5$\underline{\text { los-libros-de-estilo-en-el-ciberperiodismo-de-la-web-2-0.pdf }}$

Vellón Lahoz, F. J. (2013). Norma y estilo en los libros de redacción. Hacia un modelo lingüístico del discurso informativo. Salamanca:

Comunicación Social Ediciones y Publicaciones.

\section{Otros documentos}

Arbeitsgemeinschaft der öffentlich-rechtlichen Rundfunkanstalten der Bundesrepublik Deutschland (2017). ARD-Berich 2015/16 und ARD-Leitlinien 2017/18 für Das Erste. Recuperado el 21 de mayo de 2018, de https://www.daserste.de/specials/ueber-uns/ard-leitlinien2017-2018-100.pdf

British Broadcasting Corporation (2017a). News Style Guide.

Recuperado el 21 de mayo de 2018, de http://www.bbc.co.uk/academy/journalism/news-style-guide

British Broadcasting Corporation (2017b). BBC Annual Plan for 2017/2018. Recuperado el 21 de mayo de 2018, de http://downloads.bbc.co.uk/aboutthebbc/insidethebbc/howwework $\angle$ reports/pdf/bbc annual plan 2017 final.pdf

British Broadcasting Corporation (2017c). BBC Values. Recuperado el 21 de mayo de 2018, de http://www.bbc.co.uk/academy/journalism/values

Bayerischer Rundfunk (2013). Richtlinien für Programme und Telemedienangebote des Bayerischen Rundfunks. Recuperado el 24 de mayo de 2018, de https://www.br.de/unternehmen/inhalt/rundfunkrat/rechtsgrundla gen-publikationen-100.html

Corporación de Radio y Televisión Española (2017). Manual de Estilo de RTVE. Recuperado el 21 de mayo de 2018, de http://manualdeestilo.rtve.es/ 
France Télévisions (2011). Charte des Antennes. Recuperado el 21 de mayo de 2018, de

https://www.francetelevisions.fr/charte des antennes

Yleisradio (2017). Ylen ohjelmatoinminnan ja sisältöjen eettiset

ohjeet. Recuperado el 21 de mayo de 2018, de

https://yle.fi/aihe/artikkeli/2017/11/20/ylen-ohjelmatoiminnan-jasisaltojen-eettiset-ohjeet

Yleisradio (2018). Ylen Uutis-ja akamkohtaistoiminnan journalistiset periaatteet. Recuperado el 21 de mayo de 2018, de https://yle.fi/aihe/artikkeli/2018/05/16/ylen-uutis-jaajankohtaistoiminnan-journalistiset-periaatteet

\section{Reconocimientos de la investigación}

- Este capítulo está elaborado en el marco del proyecto Usos y preferencias informativas en el nuevo mapa de medios en España: modelos de periodismo para dispositivos móviles (Referencia: CSO2015-64662-C4-4-R) y del proyecto Indicadores de gobernanza, financiación, rendición de cuentas, innovación, calidad y servicio público de las RTV europeas aplicables a España en el contexto digital (Referencia: CSO2015-66543-P) del Ministerio de Economía y Competitividad (Gobierno de España) y cofinanciado por el fondo estructural FEDER. Forma parte también de las actividades promovidas a través de la Red Internacional de Gestión de la Comunicación XESCOM (Referencia: ED341D R2016/019), apoyada por la Consellería de Cultura, Educación e Ordenación Universitaria de la Xunta de Galicia.

- El autor Jorge Vázquez-Herrero es beneficiario del programa de Formación del Profesorado Universitario financiado por el Ministerio de Educación, Cultura y Deporte (Gobierno de España). 


\title{
E1 servicio audiovisual público como memoria y patrimonio documental
}

\author{
Mercedes Caridad Sebastián \\ Sara Martínez Cardama \\ Fátima García López \\ Ana María Morales García \\ Universidad Carlos III de Madrid
}

PARA CITAR: Caridad, M., Martínez, S., García, F. y Morales, A.M. (2018). El servicio audiovisual público como memoria y patrimonio documental. En PérezSeijo, S., Rodríguez-Castro, M. y Túñez-López, M. (Eds.), Debates sobre valores e indicadores del servicio audiovisual público en Europa (pp. 47-61). Cuadernos Artesanos de Comunicación, cac142. La Laguna (Tenerife): Latina. DOI: 10.4185/cac142

\section{Resumen}

Se presenta una reflexión sobre el concepto amplio de Patrimonio audiovisual y su evolución. De esta manera, se presentan las principales normativas y regulaciones a nivel internacional y europeo que lo configuran como memoria colectiva y le garantizan especial protección. Se presentan también los diferentes modelos estatales de las estructuras de conservación más prototípicos como es el caso de Reino Unido, Francia, Holanda y España, que difieren en el mayor o menor grado de protección estatal sobre el mismo, así como en el tipo de organismos responsables de su preservación. Se concluye estableciendo los retos futuros a los que todavía se enfrentan los países para la difusión, preservación y reutilización de tan importante legado. 
Palabras clave: Archivos audiovisuales, Patrimonio audiovisual, Unión Europea, estructuras de conservación, preservación.

\section{Introducción}

Con la llegada del cine sonoro, desde 1929 comienza la preocupación por la conservación y creación de archivos audiovisuales. La percepción de su conservación fue, por tanto, bastante tardía. Sin embargo, esta nueva forma de expresión cultural pronto demandó exigencias de preservación, englobadas teóricamente en el concepto de Patrimonio cinematográfico, entendido este como el "Conjunto de bienes y expresiones (tangibles o intangibles) que nos remitan al fenómeno cinematográfico en cualquiera de sus manifestaciones, siempre y cuando sea entendido como manifestación cultural, y, por tanto, reflejo de la actividad humana en una sociedad determinada" (Iáñez Ortega, 2011).

Sin embargo, en la actualidad a la hora de hablar de productos audiovisuales a efectos de conservación la realidad es más amplia y se extiende más allá del cine. Así, la Recomendación sobre la Salvaguarda de las Imágenes en movimiento, de la UNESCO del 27 de octubre de 1980, engloba todo este patrimonio bajo el término imágenes en movimiento, siendo estas:

"cualquier serie de imágenes registradas en un soporte (independientemente del método de registro de las mismas y de la naturaleza del soporte -por ejemplo, películas, cinta, disco, etc.utilizado inicial o ulteriormente para fijarlas) con o sin acompañamiento sonoro que, al ser proyectadas, dan una impresión de movimiento y están destinadas a su comunicación o distribución al público o se producen con fines de documentación; se considera que comprenden entre otros, elementos de las siguientes categorías:

a) producciones cinematográficas (tales como películas de largo metraje, cortometrajes, películas de divulgación científica, documentales y actualidades, películas de animación y películas didácticas);

b) producciones televisivas realizadas por o para los organismos de radiodifusión; 
c) producciones videográficas (contenidas en los videogramas) que no sean las mencionadas en los apartados a) y b)".

La concepción de Patrimonio Audiovisual iría más allá de los propios soportes y formatos, abarcando todo un conjunto de materiales que ayudan a la comprensión del "registro audiovisual" (libros, equipos, recortes de prensa...). Asimismo, adquieren una doble consideración: la de patrimonio mueble y la de patrimonio inmaterial. Ambas propiedades han de ser tenidas en cuenta a la hora de tener en cuenta su preservación.

Esta consideración de acervo cultural de los archivos audiovisuales viene avalada por organismos internacionales con competencias en la materia como la UNESCO, el Consejo de Europa, el Parlamento Europeo y otras asociaciones de carácter profesional como ICA/CIA (Consejo Internacional de Archivos), que cuenta con un Comité especialmente dedicado a los materiales audiovisuales, el CICT (Consejo Internacional del Cine y de la Televisión) y la FIAT/IFTA (Federación Internacional de Archivos de Televisión), que vienen realizando recomendaciones orientadas a la conservación y preservación de este patrimonio.

Una de las diferencias clave en cuanto a la preservación de lo que se conoce de manera aglutinadora como "Patrimonio Audiovisual", es la titularidad y capacidad de maniobra de las instituciones públicas. Así, mientras sobre patrimonio cinematográfico se han realizado importantes iniciativas reguladoras a nivel internacional, así como de cooperación, en materia de patrimonio televisivo, los depósitos de las imágenes están en muchos casos en manos de cadenas de televisión o productoras, por lo que esta privacidad hace que articular políticas reguladoras de manera coordinada sea complejo.

Uno de los aspectos definitorios de la preservación, es la del acceso que debe de garantizarse como fin último. Uno de los retos de filmotecas y centros de documentación audiovisual sigue siendo encontrar fórmulas para garantizar el acceso sin infringir ninguna normativa vigente ni dañar el documento original. (Caridad et. al, 2011). Por ello, las múltiples aproximaciones en preservación desde la documentación audiovisual giran sobre la digitalización. 
Las instituciones, al albur de proyectos internacionales de organismos con competencias en la materia, como FIAT o UNESCO, han desarrollado proyectos para la salvaguarda de estas colecciones. Así, como medida de concienciación el 27 de octubre es el día elegido por la Conferencia General de la Unesco como "Día Mundial del Patrimonio Audiovisual". Esta institución cuenta además con el programa "Archivos Audiovisuales" que tiene como fin la preservación de las colecciones que conformar el patrimonio audiovisual, comprendiendo películas, archivos de televisión y grabaciones sonoras. Uno de sus principales objetivos es el desarrollo de infraestructuras adecuadas, y la formación de profesionales para el tratamiento y preservación de estas colecciones (León-Moreno, Zapico-Alonso, Caldera-Serrano, 2016).

Las bibliotecas y archivos también deben ser conscientes del valor patrimonial de estas colecciones. Caridad et. al (2011) señalan que durante un tiempo inicial se mantuvieron al margen debido a la creencia de que el valor cultural no estaba ligado al audiovisual, la problemática de su almacenamiento y complejidad de preservación y conservación, así como la dificultad en la gestión de derechos de propiedad intelectual. Esta perspectiva ha cambiado con los años, y las colecciones audiovisuales forman parte de archivos y bibliotecas de manera habitual, tal y como muestran las colecciones audiovisuales de bibliotecas nacionales como la Biblioteca Nacional de España y la Biblioteca del Congreso (Figuras 1 y 2).

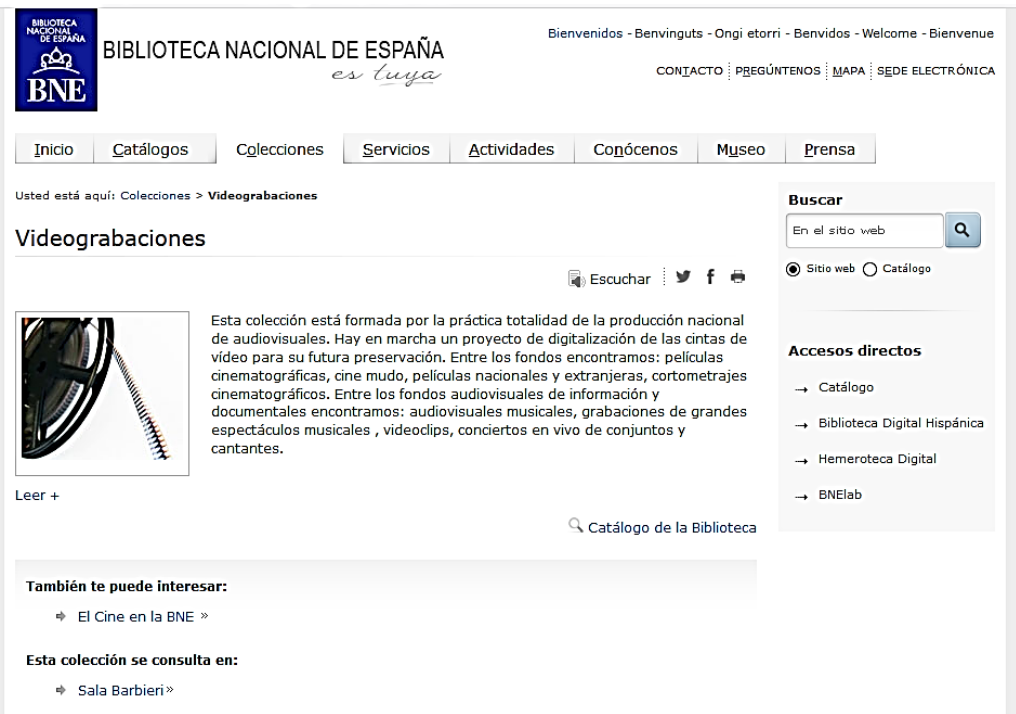

Figura 1. Colección audiovisual de la Biblioteca Nacional de España. Fuente: http://www.bne.es/es/Colecciones/Videograbaciones/ 


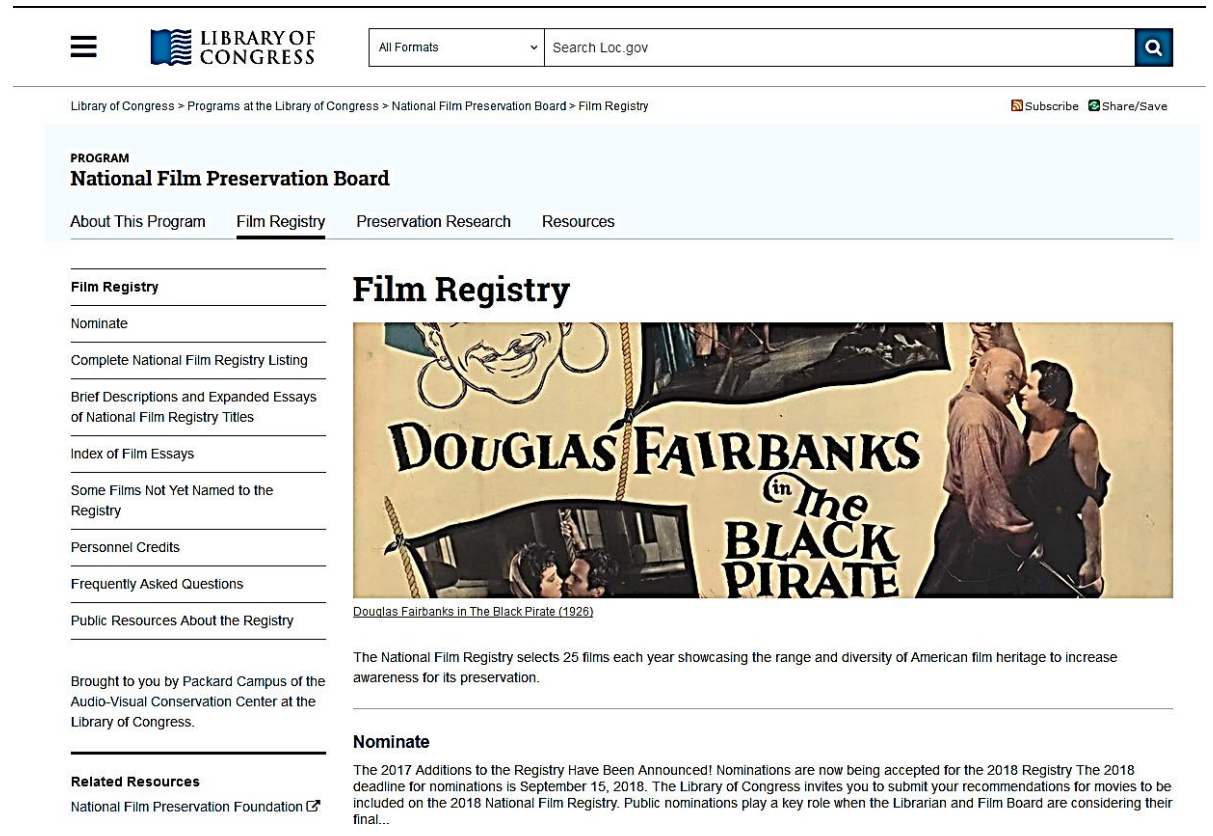

Figura 2. Colección y Programa de preservación de la Biblioteca del Congreso.

Fuente: https://www.loc.gov/programs/national-film-preservationboard/film-registry/

Otro de los elementos esenciales para la distribución de este material se debe al nacimiento de plataformas como YouTube. No obstante, a pesar de su potencial, y que ha servido para la difusión y publicación de videos antiguos, a tenor de Caridad et al (2011), no deja de ser una falsa apariencia de depósito audiovisual, cuando se trata de una plataforma social cuyo objetivo sería la distribución y no la preservación. Sin embargo, estos autores señalan muchas de las bondades de la red en relación al patrimonio audiovisual: en relación a su almacenamiento (del propio acervo audiovisual y de la documentación contextual), a su acceso inmediato y a la propia reconceptualización de documento audiovisual. Al igual que sucede en Internet en el que el documento ya no es la página web, sino fragmentos, en la documentación audiovisual cada vez se concibe menos la idea de documento cerrado y se entiende más como un asset o activo, que puede ser fragmentado.

En este sentido, se puede considerar que gracias a estos medios se han desarrollado iniciativas para la puesta en valor y explotación de estos materiales que pueden ser aprovechados para una política de gestión de contenidos en medios sociales, adoptando, por ejemplo, estrategias transmedia y crossmedia (Caridad et al, 2018, Hagedoorn y Agterberg, 2016). 
Para mayor conocimiento del potencial del patrimonio audiovisual como memoria se presentan, a continuación, los proyectos e iniciativas de colaboración y cooperación del ámbito europeo, el paraguas que suponen las directivas europeas y, posteriormente, los diferentes modelos de conservación aplicados en los principales de europeos de nuestro entorno. Como colofón, se presentan retos futuros que deben asumir los archivos audiovisuales en colaboración con los agentes implicados para la salvaguarda y mejor explotación de nuestra memoria colectiva audiovisual.

\section{Marco regulatorio audiovisual europeo y estructuras de conservación}

Los primeros intentos de una política audiovisual de la Unión Europea aparecen a principio de la década de los ochenta ligados al desarrollo de la industria de las telecomunicaciones, especialmente a la radiodifusión por satélite que dio lugar a la proliferación de estaciones de radio y televisión comerciales en Europa occidental. En el fondo de esta política subyace la idea de la libre circulación tanto de infraestructura como de contenido. Muestra de esto, es la "Directiva de televisión sin fronteras ( $\mathrm{TVwF}$ )" (Consejo de las Comunidades Europeas, 1989).

Una vez superada la etapa infraestructural, las políticas de la Unión se centran en la década de los 1990 en los contenidos, gracias al programa comunitario MEDIA (Mesures pour Encourager le Développement de l'Industrie Audiovisuelle). El programa MEDIA previó medidas de apoyo a la industria europea de cine y televisión para que esta industria sea más competitiva y más capaz de satisfacer las necesidades de las cadenas de televisión.

En la misma línea, en 1992 se crea el European Audiovisual Observatory que intenta mejorar la transferencia y transparencia de la información en esta industria. El Observatorio presta servicio público a la Comunidad Europea y ofrece una comparativa de la industria audiovisual de 41 países diferentes, profundizando en un análisis tanto nacional, como regional.

No obstante, todas estas iniciativas nacen para potenciar la creación y el fortalecimiento de una industria audiovisual europea, no para la preservación per se. 
No será hasta la llegada del nuevo milenio, cuando la Unión Europea comience a ser consciente de manera efectiva de la importancia de este patrimonio vital para nuestra memoria colectiva. No debemos olvidar que durante esos años la mayoría de los países europeos ya contaban con una legislación nacional para proteger su cine, muy ligada al factor industrial. Por tanto, es importante, el cambio de orientación que la Unión Europea establece en las políticas de esta época.

La primera consideración de archivos cinematográficos europeos como parte del patrimonio aparece en la Resolución del Consejo (1), de 26 de junio de 2000, relativa a la conservación y promoción del patrimonio cinematográfico europeo (2000/C 193/01), en ella se señala que estos "albergan un vasto patrimonio representativo de la historia del cine, integrado por la mayor parte de lo que ha sobrevivido de la producción europea y por una parte significativa de lo producido en otros".

En esta resolución ya se llama la cooperación entre estados para hacer un estudio transnacional sobre la situación de estos archivos, armonización en temas de derecho de la propiedad intelectual, restauración y conservación y fomento de la constitución gradual de una red de bases de datos de los archivos europeos.

Posteriormente, las siguientes iniciativas amplían la concepción de patrimonio audiovisual, incluyendo además del cine, las producciones de diferentes tipologías. Así, surge la Comunicación de la Comisión al Consejo, al Parlamento Europeo, al Comité Económico y Socialy al Comité de las Regiones sobre determinados aspectos jurídicos vinculados a las obras cinematográficas y a otras producciones del sector audiovisual en 2002, donde ya se plantea la necesidad de un depósito legal de las obras audiovisual, así como, la creación de un registro europeo (o la interconexión de los registros nacionales), medidas orientadas a preservación del patrimonio audiovisual europeo.

En 2005, una nueva recomendación titulada Recomendación del Parlamento Europeo y del Consejo, de 16 de noviembre de 2005, relativa al patrimonio cinematográfico y la competitividad de las actividades industriales relacionadas, ya aúna dos facetas importantes del patrimonio audiovisual: la consideración de acervo cultural y su explotación. En esta iniciativa realizan 22 recomendaciones a los estados miembros, entre las que destacan: 
- La adopción, a más tardar el 16 de noviembre de 2007, de medidas legislativas, administrativas u otras adecuadas, que garanticen que las obras cinematográficas que formen parte de su patrimonio audiovisual sean sistemáticamente recogidas, catalogadas, conservadas y restauradas, de forma que estén accesibles para usos pedagógicos, culturales y de investigación, así como otros usos similares no comerciales, respetando en todos los casos los derechos de autor y derechos afines.

- La designación de organismos idóneos encargados de llevar a cabo las tareas de interés público descritas en el punto 2 con independencia y profesionalidad, garantizándoles los mejores recursos técnicos y económicos disponibles.

- La adopción de medidas adecuadas para incrementar el grado de utilización de las tecnologías digitales y de las nuevas tecnologías en la recopilación, catalogación, conservación y restauración de las obras cinematográficas.

- La recopilación sistemática de las obras cinematográficas que formen parte de su patrimonio audiovisual mediante la obligación legal o contractual de depositar al menos una copia de alta calidad de dichas obras cinematográficas en los organismos designados.

Estas iniciativas de cooperación se han materializado en la actualidad en proyectos como el portal EUscreen, basado la colaboración de una red de archivos audiovisuales, que ofrece a través de un único interfaz, colecciones audiovisuales de manera gratuita (Figura 3).

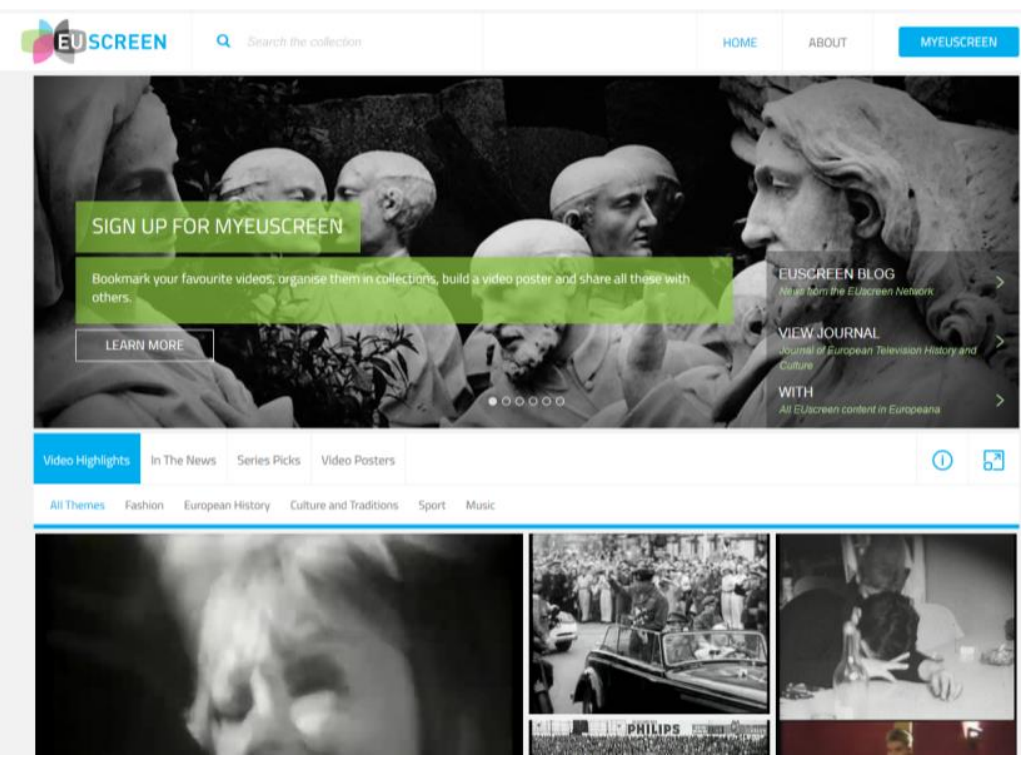

Figura 3. Proyecto EuScreen. Fuente: http://www.euscreen.eu/ 
Estos proyectos se nutren, en parte, de las colecciones audiovisuales de los países miembros. A pesar de que muchas de las iniciativas insisten en la conveniencia de un depósito legal para salvaguardar y conservar la producción audiovisual nacional de cada país, todavía existen muchos países carecen de una legislación ad hoc. Si nos centramos en los archivos de televisión, por ejemplo, en sus numerosos estudios el tema, Hidalgo $(2013,2014,2017)$ subraya que la falta de políticas de conservación, preservación y acceso a los documentos que albergan suele ser la práctica habitual.

Respecto a las estructuras de conservación y/o difusión tampoco existe un único modelo. Entre las diferentes situaciones encontramos países en los que los documentos audiovisuales están sujetos a una Ley de Depósito Legal, otros cuya responsabilidad jurídica depende de organismos públicos, a veces creados ex profeso, y otros cuya gestión depende de la propia Biblioteca Nacional del país.

Una visión global de las diferentes estructuras de conservación de algunos países miembros permite ejemplificar de manera paradigmática los diferentes modelos de gestión y conservación del patrimonio audiovisual. Se muestran a continuación la gestión de este patrimonio en los siguientes países europeos: Reino Unido, Francia, Holanda y España

\section{Reino Unido}

Los archivos audiovisuales en el Reino Unido no están sujetos a una norma legal de depósito. La gestión es compartida por la propia BBC y el NFA (National Film Archive) (Caridad et al., 2011). Esta institución, creada en 1935, que forma parte del British Film Institute (BFI) es la responsable de las funciones de preservación y acceso tanto de películas cinematográficas como de programas de televisión. Su archivo conserva el material de la BBC para su preservación desde 1950. Por su parte, la BBC conserva en archivo parte de su producción correspondiente a las primeras emisiones y al periodo después de la segunda guerra mundial (Hanford, 1986).

\section{Francia}

Francia es uno de los países que ha ido adoptando paulatinamente una auténtica política de conservación y donde se reconoce el valor patrimonial de los archivos audiovisuales desde época más temprana. 
Desde su creación en 1975, el INA es el organismo público encargado garantizar la conservación y preservación de los archivos de radio y televisión.

En 1992 se encomienda además al INA el control del depósito legal de los documentos de radio y televisión de todas las cadenas públicas y privadas. Para su gestión, en 1995 se crea la Inathèque de France, estableciéndose el primer centro de consulta en la Biblioteca Nacional de Francia en 1998. Asimismo, desde 2006 es responsable también junto con la $\mathrm{BnF}$, del depósito legal de los sitios web de medios de comunicación franceses.

El INA se configura desde su creación como institución pública de carácter patrimonial siendo, además, una entidad de carácter industrial y comercial encargada también de la explotación de los archivos de televisión de todas las cadenas públicas y de aquellas privadas que han suscritos convenios con el INA.

Por su parte, el Centre National de la Cinématographie (CNC) es el organismo encargado de la gestión del Depósito Legal del cine francés. Desde 1946 se encarga de la gestión del fondo patrimonial cinematográfico (Cinemateca francesa, la Biblioteca del cine, Cenemateca de Toulose e Instituto Lumière de Lyon) (Caridad et al., 2011).

\section{Holanda}

Holanda es otro de los países que cuenta con una institución pública como el Netherlands Institute for Sound and Vision para la preservación y conservación del patrimonio audiovisual nacional. La configuración de un organismo nacional con responsabilidad en esta área comienza a gestarse a mediados de la década de 1990. Así, en 1997 se crea el Dutch Audiovisual Archive que fusiona los archivos audiovisuales de la radio y televisión públicas holandesas, el RVD (Servicio de Información de Holanda), el Dutch Film and Science Foundation y el Broadcasting Museum in the Netherlands.

Desde 2006, bajo la denominación ya de Netherlands Institute for Sound and Vision, añade a su misión patrimonial la función museística, convirtiéndose actualmente en una institución para la cultura de los medios que se centra en recopilar y preservar la mayor parte del 
patrimonio audiovisual de los Países Bajos y ponerlo a disposición del mayor número de usuarios posible.

\section{España}

El valor del patrimonio audiovisual español es reconocido en diferentes leyes y normativas, sin embargo, la responsabilidad y procedimientos para su salvaguarda sigue siendo difusa. Precisamente, los "programas audiovisuales emitidos por servicios de comunicación audiovisual" figuran entre los "excluidos de depósito legal" en la última Ley de Depósito Legal de 29 de julio de 2011(Hidalgo, 2014). España sería, por tanto, uno de los países en el que la preservación y conservación del patrimonio audiovisual de las televisiones es responsabilidad de las propias cadenas. En el caso concreto de la televisión pública estatal, es la propia Corporación de RTVE la responsable de la conservación de sus archivos históricos audiovisuales (Hidalgo, 2013).

Desde 1953, la responsabilidad de la gestión del patrimonio fílmico español corresponde a Filmoteca Española. Este organismo tiene además la misión de recuperar, investigar y conservar el patrimonio histórico, así como archivar y preservar la producción cinematográfica producida en la actualidad. La institución cuenta entre sus fondos con colecciones de especial relevancia como los archivos de NO-DO y el archivo de la Guerra Civil Española (Caridad et al., 2011).

\section{Retos futuros}

Los retos de todos los archivos a gran escala se debaten todavía en los principales foros profesionales. El más reciente de las propuestas es la propuesta de un Think Tank elaborada por miembros de Netherlands Institute for Sound and Vision (Kaufman, 2018). En forma de White paper realiza recomendaciones necesarias que han de ser aplicables a nivel global:

a) La construcción de un inventario global. Se exponen como ejemplo las propuestas de un catálogo colectivo a semejanza de WorldCat o los proyectos Europeana Film Gateway o EuScreen pero aplicables a nivel mundial. Asimismo, menciona la importancia de la interoperabilidad en este inventario, y que su información pudiera ser reutilizada a partir de tecnología de datos enlazados. 
b)La mejora de la capacidad de descubrimiento y búsqueda de los propios archivos audiovisuales.

c) La construcción de relaciones con el sector privado.

d) Ampliar los límites de la investigación en archivos audiovisuales (a nivel de diseño de sistemas y de preservación).

e) Implicación mayor con plataformas sociales o colaborativas (i.e Wikipedia, especialmente a través de la plataforma Commons).

f) Promover licencias copyleft para los materiales audiovisuales generados en estos archivos. Especialmente aquellos que se generen en proyectos cooperativos como PrestoCentre.

g) Garantizar la futura sostenibilidad de los mismo explorando nuevos modos de obtener beneficios. Se ha de tener como modelo nuevos mecanismos de medición e impacto como los presentados para Europeana en el Europeana Impact Playbook (2017) que presenta nuevas e innovadores mediciones del impacto social y económico del patrimonio cultural.

h) Creación de dinámicas de trabajo más abiertas con los demás responsables del trabajo audiovisual. Así, el archivo audiovisual no puede entenderse como el final de la cadena documental. Estos documentalistas han de trabajar de manera conjunta con creadores y productores en todas las etapas del proceso.

i) Potenciar el rol educativo de los archivos audiovisuales y de sus profesionales, especialmente para conectar con el público joven que vive bajo el poder de las imágenes.

j) Implicar más a los archivos audiovisuales en el escenario político-cultural de nuestra época. Quedan importantes batallas como dar a conocer la importancia de los proyectos de digitalización al gran público, reformular el copyright para estas colecciones o aportar el conocimiento y bagaje en unidades de Fact-checking, para desmentir o rastrear el origen de información audiovisual o imágenes publicadas y que puedan suponer sesgos en la ciudadanía. Tal es el caso, del proyecto cooperativo Invid Project (Figura 4) para la verificación de videos en la que los archivos audiovisuales deben tener un papel esencial. 


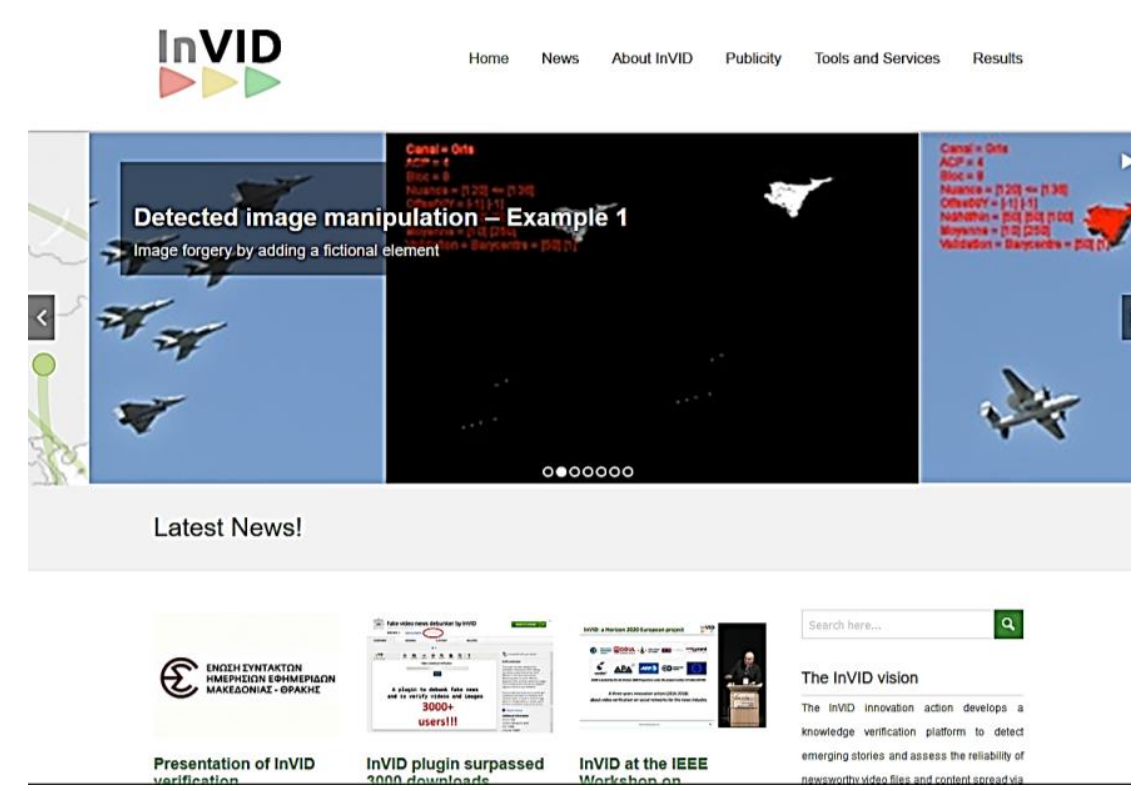

Figura 4 Invid Project. Fuente: http://www.invid-project.eu/

\section{Referencias bibliográficas}

Caridad, M. et. al. (2011). Documentación Audiovisual. Madrid: Síntesis

Caridad, M. et al. (2018). Los archivos audiovisuales de televisión: estrategias para su revalorización en un entorno transmedia. Revista Latina de Comunicación Social, 73, 870-894.

Center for Reseach and Technology Hellas - Information

Technologies Institute. Invid Project. Recuperado el 12 de junio de 2018 http://www.invid-project.eu/

Comisión Europea (2002). Comunicación de la Comisión al Consejo, al Parlamento Europeo, al Comité Económico y Social y al Comité de las Regiones sobre determinados aspectos jurídicos vinculados a las obras cinematográficas y a otras producciones del sector audiovisual. (COM/2001/0534 final). Recuperado el 12 de junio de 2018 https://eur-lex.europa.eu/legalcontent/ES/TXT/?uri=CELEX:52001DC0534

Comisión Europea (2005). Recomendación del Parlamento Europeo y del Consejo, de 16 de noviembre de 2005, relativa al patrimonio cinematográfico y la competitividad de las actividades industriales relacionadas. Recuperado el 12 de junio de 2018 http://eur-lex.europa.eu/legal- 
content/ES/TXT/?uri=uriserv:OJ.L .2005.323.01.0057.01.SP

$\underline{\mathrm{A}}$

Comisión Europea (2018). Europe Creative. Programa Media.

Recuperado el 12 de junio de 2018.

https://ec.europa.eu/programmes/creative-europe/media es

Consejo de las Comunidades Europeas (1989). Directiva

89/552/CEE del Consejo, de 3 de octubre de 1989, relativa a la coordinación de determinadas disposiciones legales,

reglamentarias y administrativas de los Estados miembros sobre el ejercicio de actividades de radiodifusión televisiva (3 de octubre de 1989). Recuperado el 12 de junio de 2018.

https://eur-lex.europa.eu/legal-

content/ES/AUTO/?uri=celex:31989L0552

Consejo de la Unión Europea (2000). Resolución del Consejo de 26 de junio de 2000 relativa a la conservación y promoción del patrimonio cinematográfico europeo (2000/C 193/01).

Recuperado el 12 de junio de 2018. https://eur-

lex.europa.eu/legal-

content/ES/TXT/HTML/?uri=CELEX:32000Y0711(01)\&fro $\underline{\mathrm{m}=\mathrm{EN}}$

European Audiovisual Observatory (2018). Recuperado el 12 de junio de 2018. https://www.obs.coe.int/en/web/observatoire/

European Commission. (2018) Euscreen. Recuperado el 12 de junio de 2018. http://euscreen.eu/about.html

Europeana Foundation (2017). Europeana Impact Playbook. Recuperado el 12 de junio de 2018. https://pro.europeana.eu/what-wedo/impact

Kaufman, P.B. (2018) Towards a New Audiovisual Think Tank for Audiovisual Archivists and Cultural Heritage Professionals. Hilversum:

Netherlands Institute for Sound and Vision, 2018.

Hagedoorn B. y Agterberg B. (2016). The End of the Television Archive as We Know It? The National Archive as an Agent of Historical Knowledge in the Convergence Era. Media and Communication, 4(3). 
Hanford, A. (1986). Panorama de los archivos audiovisuales. Madrid: RTVE.

Hidalgo, P. (2013). Prevenir la amnesia colectiva: El acceso público a los archivos de televisión. Documentación de las Ciencias de Información, 36, 143-166.DOI: 10.5209/rev_DCIN

Hidalgo, P. (2014). El archivo de RTVV Patrimonio Audiovisual de la Humanidad, Métodos de información, 5 (8), 17-30. DOI:10.5557//IIMEI5-N8-017030.

Hidalgo, P. (2017). Preservación del patrimonio audiovisual de televisión. El archivo de Televisión Española (TVE): de los orígenes a la digitalización. Director: Félix del Valle Gastaminza. Tesis doctoral. Madrid: Universidad Complutense de Madrid.

Iáñez Ortega, M. (2011). El Patrimonio cinematográfico en el Museo. e-rph, Revista Electrónica de Patrimonio Histórico, 9, 1-16

León-Moreno, J, Zapico-Alonso, F. y Caldera-Serrano, J. (2016). $¿$ Archivos audiovisuales aún sin digitalizar? seguridad, preservación y amortización. Cuadernos de Documentación Multimedia, 27(2), 178-190. DOI:10.5209/CDMU.54488

UNESCO. Recomendación sobre la Salvaguardia y la Conservación de las Imágenes en Movimiento, 27 de octubre de 1980. Recuperado el 12 de junio de 2018. http://portal.unesco.org/es/ev.php$\underline{\mathrm{URL}}$ ID $=13139 \& \mathrm{URL}$ DO=DO TOPIC\&URL SECTION $\equiv 201 . \mathrm{html}$ 



\title{
E1 servicio audiovisual público en la era de la post-emisión
}

\author{
Francisco Campos-Freire \\ Universidade de Santiago de Compostela
}

PARA CITAR: Campos-Freire, F. (2018). El servicio audiovisual público en la era de la post-emisión. En Pérez-Seijo, S., Rodríguez-Castro, M. y Túñez-López, M. (Eds.), Debates sobre valores e indicadores del servicio audiovisual público en Europa (pp. 63-77). Cuadernos Artesanos de Comunicación, cac142. La Laguna (Tenerife): Latina. DOI: $10.4185 /$ cac142

\section{Resumen}

El objeto de esta parte es analizar la perspectiva del servicio audiovisual público (SAP) o de los medios de servicio público audiovisual (PSM, en sus siglas de inglés) dentro del actual ecosistema digital de acceso a la información y comunicación. Partiendo de una síntesis de concepciones tradicionales o coyunturales sobre el SAP, se analizan las estrategias y tendencias de regulación, gobernanza y financiación de la radiotelevisión pública en Europa ante la tercera década del siglo XXI, en la que los flujos de la comunicación audiovisual son cada vez más discontinuos, desprogramados, fragmentados y accesibles a través de diversas formas y plataformas.

Palabras clave: Regulación, gobernanza, financiación, radiotelevisión pública, audiovisual en la nube. 


\section{Introducción}

La radiodifusión tradicional se origina y desarrolla sobre el concepto de broadcasting (de uno a muchos puntos) de difusión amplia, base de la universalidad del servicio público (Public Broadcasting Service, PBS), pero esa forma de emisión y difusión varía cuando las tecnologías digitales se hacen más flexibles y permiten narrowcasting o acceso más diversificado, selectivo, personalizado y fragmentado. Al mismo tiempo, el espectro radioeléctrico terrestre de difusión sobre el que se desarrolla la televisión tradicional universal empieza a ser codiciado y arrebatado por la telefonía móvil, que desplaza a aquélla al espacio más cerrado del satélite, cable e Internet.

El paso de uno a otro sistema de difusión es el salto de la unidireccionalidad a la bidireccionalidad, multidireccionalidad e interactividad, pero también la ruptura de la continuidad de la programación (Lange, 2011; Missika, 2006), de la sincronía a la asincronía del acceso y, por lo tanto, de la quiebra de la cohesión de las emisiones como "conjunto de programas difundidos sin interrupción" (RAE). Frente a los sistemas tradicionales de transmisión terrestre, de satélite y cable, cobra preponderancia la difusión de las plataformas de servicios desde la nube, es decir a través de Internet.

La transición de la paleo televisión a la neo televisión (Eco, 1986; Casetti y Odin, 1990; Pastoriza, 1997) y post televisión (Le Diberder y Coste-Cerdan, 1988; Piscitelli, 1999; Ramonet, 2002) o meta televisión (Tous Rovisora, 2009) es de finales del pasado siglo y primera década del presente. Atendiendo al impacto de la convergencia tecnológica sobre la televisión tradicional, las políticas públicas (directivas europeas y legislaciones nacionales) reconocen más tarde que pronto -a mitad de la primera década del siglo XXI- la regulación de los servicios audiovisuales.

Pero aún tardó más en ponerse al día la regulación de la radiodifusión de servicio público, es decir, el marco para la reconversión y adaptación de la radiotelevisión pública (PSB) al nuevo horizonte del servicio audiovisual público (PSM). Los medios audiovisuales de servicio público tratan de adaptarse a la era de la post-emisión con una mochila lastrada por el deterioro de su legitimidad, credibilidad, reputación, 
financiación, gobernanza e inadaptación a la innovación constante por parte de su pesada, anticuada y rígida estructura empresarial.

Esas cargas condicionan el debate actual sobre la existencia y supervivencia del servicio audiovisual público, lo que en este capítulo abordaremos a continuación con respecto al contexto de los países de la Unión Europea. La radiotelevisión pública existe en todos los estados de la UE, pero lo hace con distintos modelos, estructuras y perspectivas.

Partiendo del modelo tradicional y extendido de Hallin y Mancini (2004, 2008, 2011) y de la clasificación manejada por Karen Donders y Sofie-Anne Vanhaeght (2015) sobre la transformación digital del servicio audiovisual público, resumimos a continuación cinco situaciones actuales sobre la regulación, gobernanza, financiación y estado de la radiotelevisión pública en Europa.

\section{De 3 modelos a 5 situaciones}

Es clásica -aunque algo desactualizada, a pesar de haber sido revisada y extendida a los países de Europa oriental y de otros continentes- la clasificación realizada por los profesores Hallin y Mancini $(2004,2011)$ sobre los sistemas mediáticos comparados de las democracias occidentales, en las que encuadran la regulación y gobernanza del servicio audiovisual público, dentro de tres modelos: el liberal anglosajón; el democrático corporativo del norte europeo; y el pluralista polarizado del sur o mediterráneo.

Tras estudiar 18 democracias occidentales ( 9 países del norte de Europa, 5 del sur europeo y 4 del arco anglo atlántico), Hallin y Mancini clasifican los modelos mediáticos en relación a sus sistemas políticos y de regulación en los tres tipos: liberal (países atlánticos anglosajones, Reino Unido, Irlanda y norteamérica); democrático corporativo (Austria, Bélgica, Dinamarca, Finlandia, Alemania, Países Bajos, Noruega, Suecia y Suiza); y pluralista polarizado (Francia, Grecia, Italia, Portugal y España).

Los análisis de Hallin y Mancini, pese a estar superados por algunos aspectos y cambios producidos en la sociedad digital que todavía no eran patentes a principios del siglo XXI, cuando realizaron su primera investigación, marcan encuadres que siguen vigentes en el 
establecimiento de los sistemas de gobernanza de los medios audiovisuales públicos de comunicación.

Según el análisis de Hallin y Mancini, el sistema de televisión pública en el modelo pluralista polarizado de los países mediterráneos es gubernamentalizado, prevalece la subvención como sistema de financiación y su control es partidistamente politizado. En el sistema democrático corporativo (países nórdicos europeos) el servicio audiovisual público está más y mejor controlado democráticamente, se financia a través de canon preferentemente y su control refleja también mayor representación sociopolítica. $\mathrm{Y}$ en el sistema liberal la radiotelevisión pública está regulada democráticamente, la financiación es a través del canon y su control se basa en la garantía de la independencia.

Rasmus Kleis Nielsen y Geert Linnebank (2011) publicaron otro estudio, basado en las políticas públicas de ayudas a los medios de comunicación, que introduce algunas variantes complementarias al trabajo seminal de Hallin y Mancini, autores que también extendieron su propia investigación a otros países como Polonia, Lituania, Rusia, Israel, Líbano, Arabia Saudita, Sudáfrica y Tailandia (Comparing Media Systems Beyond the Western World, 2011). Los países que no encajan en los tres primeros modelos, los sitúan Hallin y Mancini en una cuarta tipología híbrida que mezcla características de los anteriores.

Junto al reto de la gobernanza y la financiación, el servicio audiovisual público en esta segunda década del siglo XXI se enfrenta también a la transformación y transición digital que imponen las nuevas formas de consumo y acceso de los usuarios, así como la multiplicación de la competencia de los nuevos operadores de las plataformas que están transformando los mercados tradicionales de televisión (Evens y Donders, 2018).

Las investigaciones de Karen Donders identifican tres categorías o niveles en las estrategias de los grupos audiovisuales públicos según su regulación, gobernanza y progreso en la transformación y adaptación digital:

1. Países del norte de Europa con fuerte independencia editorial, poca regulación pública, pioneros en la prioridad de la innovación para 
liderar la transformación digital frente al sector privado y, sobre todo, ante las nuevas plataformas.

2. Países del Reino Unido, Alemania, Bélgica y Holanda también con independencia editorial, pero sujetos a una fuerte regulación pública y tensiones digitales frente al sector privado, pese a que colocan la innovación en el primer plano de sus planes estratégicos.

3. Países del sur de Europa con poca independencia editorial, menor regulación pública, pero fuerte influencia gubernamental o de los partidos políticos sobre la gobernanza del servicio audiovisual público, en el que la apuesta digital es un esfuerzo más experimental que real por las restricciones de su financiación. Son los que han tardado más en incorporar la prioridad estratégica de la innovación digital, que también empieza a penetrar en sus organizaciones a pesar del lastre de sus obsoletas estructuras.

Ahora, cerca del final de esta segunda década del siglo XX, la situación de la gobernanza, financiación e innovación del servicio audiovisual público en Europa es todavía más fluida. Los problemas y presiones no sólo no se han reducido o contenido, sino que se han incrementado frente a los competidores tradicionales y las nuevas plataformas digitales, así como también por los rechazos a su elevada financiación y las agresivas campañas de nuevos partidos populistas que usan las redes sociales y las fake news para desacreditar la influencia que no pueden controlar. Con este panorama podemos establecer cinco situaciones, categorías o tipologías:

1. Tipología estable de regulación, gobernanza, financiación e independencia. A este grupo se pueden adscribir las televisiones públicas británica y de los países del norte de Europa. Pero el prototipo de ese modelo es BBC Corporation, que se rige por una Carta Real estable que se renueva cada diez años. La vigente Royal Charter, que entró en vigor el 1 de enero de 2017, garantiza la gobernanza y financiación de la BBC hasta 2027. La gobernanza se articula a través de tres estructuras, dos de ellas internas (consejo de administración y organización ejecutiva) y una externa (atribuída al regulador convergente del audiovisual y las telecomunicaciones, OFCOM). El presidente del consejo de administración es consensuado por el partido 
del gobierno a partir de una propuesta de reconocida independencia. Los otros miembros del consejo de administración son elegidos tres por cada una de las naciones del Reino Unido, tres de entre los cargos ejecutivos y los restantes de entre personalidades independientes de reconocido prestigio y competencia.

La Carta Real 2017-27 de la BBC mantiene el pago de la licencia o canon de televisión por unidad familiar o empresarial como medio esencial de financiación, incrementado según la evolución del coste de la vida y con exención para jubilados y desempleados. Pero en el ámbito de la financiación también abre la puerta a poder incrementar los ingresos a través de nuevos modelos de negocio y alianzas comerciales que sean compatibles con la misión de servicio público.

El vigente servicio audiovisual público británico se basa en cinco propósitos: a) ofrecer noticias veraces e información imparcial; b) contenidos de aprendizaje y entretenimiento para públicos infantiles y jóvenes; c) creatividad, calidad y diferenciación; d) proximidad y diversidad de las naciones y regiones; y representar adecuadamente al Reino Unido en el mundo.

2. Tipología tradicionalmente estable pero actualmente sometida a debate y revisión. Algunos países de los modelos liberal y corporativo democrático, tradicionalmente estables en financiación y gobernanza, están envueltos en procesos de ajuste económico, disputas sobre la contribución de su fuente principal de ingresos y de crítica abierta por parte de algunas fuerzas política. En esta categoría sobrevenida podemos situar a Irlanda, Alemania, Dinamarca, Austria, Suiza y otros países de Europa oriental.

Los dos principales focos de debate en este modelo son el sistema de financiación y la discusión sobre su línea editorial, en unos casos por pretensiones de influencia de fuerzas políticas gobernantes o emergentes y en otros por la reticencia de los contribuyentes a pagar el canon. La crítica sobre la financiación pone en la guillotina el sistema de cuotas, un impuesto directo impopular por alto e inadecuado porque grava de igual manera a los contribuyentes que son usuarios del servicio audiovisual público y a los que no lo son. Varios ciudadanos alemanes han llevado el sistema de canon a los tribunales y algunos incluso fueron condenados a ingresar en prisión por negarse a pagarlo. 
Dinamarca, una de las corporaciones audiovisuales públicas más estables y exitosas, ha aprobado en 2018 suprimir el sistema de canon y asumir a partir de 2019 la financiación del servicio audiovisual público -que se reduce en un 20 por ciento- con cargo a una contribución directa de los presupuestos generales del estado. Impulsado por una coalición política populista, Suiza sometió a referéndum en marzo la supresión o no del canon de la licencia de televisión, logrando aprobar la continuidad de su contribución por una amplia mayoría.

Los modelos de financiación de las radiotelevisiones públicas de Irlanda y Alemania están igualmente bajo la presión de las tarifas del impuesto que regula su contribución y, en consecuencia, de las medidas de ajuste y recorte de gastos en sus correspondientes estructuras.

El sistema de canon, que mantienen docena y media de países en Europa, es un modelo de financiación discutido por algunos contribuyentes por su falta de progresividad, pero es el que más garantías ofrece para salvaguardar la independencia porque desvincula la contribución económica de la dependencia directa del gobierno o del parlamento a la hora garantizar la sostenibilidad del servicio audiovisual público. Obliga, además, a enfocar la rendición de cuentas del servicio audiovisual público más hacia los ciudadanos y usuarios que al sistema político que los representa. Y, a la vez, permite establecer planes plurianuales autónomos de planificación al margen de las políticas presupuestarias anuales de los estados.

3. Tipología tradicionalmente inestable, sometida a vaivenes y presiones permanentes de las fuerzas políticas. En esta categoría podemos incluir a los países del modelo mediterráneo del sistema pluralista partidista; es decir, Francia, España, Italia o Grecia. No todos estos países alcanzan niveles similares de vaivenes o presiones, pero lo cierto es que todos ellos vivieron en las dos o tres últimas décadas cambios sucesivos de gobernanza y deterioro de su credibilidad, según los grados de manipulación e influencia de los partidos o coaliciones políticas gobernantes en cada uno de los estados.

El gobierno conservador de Nicolás Sarkozy emprendió en 2009 una reforma audiovisual ambiciosa sobre su sistema de gobernanza y financiación. Consolidó la contribución del canon por la prestación del servicio audiovisual público e inició el camino para la supresión de la 
publicidad, que no llegó a consumar del todo, a cambio de la aplicación de un impuesto a los operadores audiovisuales privados. La supresión de la publicidad como contribución económica al servicio audiovisual público, combinada con un canon sobre el uso del espectro radioeléctrico y subvención estatal, fue aplicada también en España en 2010 tras la aprobación de la ley 8/2009 promovida por el gobierno socialista de Rodríguez Zapatero. Pero el nuevo sistema de financiación, condicionado por la presión de los dos grupos audiovisuales privados sobre el gobierno socialista (Mani, 2017), no logró compensar los ingresos presupuestarios que RTVE tenía antes de 2010.

El gobierno de François Hollande varió el sistema de gobernanza, pero mantuvo el de financiación. Y su sucesor Emmanuel Macron puso en marcha una profunda reforma del audiovisual francés, con anticipo de recortes y ajustes económicos en Franace TV. En España, el gobierno de Mariano Rajoy varió en su primera legislatura, en 2012, el sistema de gobernanza de RTVE -elegido solo por mayoría absoluta, como habían hecho poco antes los convergentes en la CCMA catalana- y aplicó un plan de ajuste económico con repercusión sobre el sistema audiovisual público estatal y autonómico. En la segunda legislatura, en minoría política, los partidos de la oposición impulsaron una reforma del modelo de gobernanza de mayoría reforzada, bloqueado y estancado en el Congreso de los Diputados. La ausencia de mayorías reforzadas debilita la independencia de la gobernanza y la exigencia de ellas provoca también precedentes de bloqueo estériles para la trascendencia de la gestión de estas corporaciones. Faltan mecanismos intermedios que resuelvan esas contradicciones.

A pesar de las promesas electorales de reformas, tanto por parte de los nuevos como de algunos tradicionales partidos políticos, la gobernanza de todo el sistema audiovisual público español no experimentó avances sustanciales en independencia y reputación. Lo más significativo es la recuperación en 2018 de las emisiones de la radiotelevisión autonómica de Valencia, cerrada en 2013 por el gobierno del PP con notable polémica y embrollo jurídico. Dentro de la política de ajustes económicos duros, el cierre de la radiotelevisión valenciana fue parejo al de la ERT griega, interpretados ambos como ataques a la libertad de los medios (Crusafon, 2013; Tambini, 2016), aunque el foco de las 
críticas sobre su independencia no ha mejorado a partir de la recuperación de las emisiones en 2015 por parte del gobierno de Alexis Tsipras.

Tampoco en Italia los sucesivos gobiernos y coaliciones que se alternaron en el Parlamento en los últimos años lograron estabilizar un modelo de gobernanza independiente en la RAI, aunque el gobierno de Matteo Renzi consiguió mejorar el sistema de recaudación del canon, al incorporar su cobro a los recibos de suministro de energía eléctrica, como en Portugal.

4. Tipología influida o condicionada por las presiones políticas sobre la gobernanza y financiación. En esta categoría podríamos incluir los casos mencionados en el apartado anterior. La inclusión de esta categoría como modelo diferenciado del anterior trata de reflejar el grado de independencia y alto riesgo de las presiones políticas sobre el servicio audiovisual público. Hay indicadores que califican los grados de independencia de la gobernanza y financiación en los distintos países europeos. Apuntamos dos de esos indicadores: una encuesta del Eurobarómetro (2016) a 27.000 ciudadanos europeos sobre la percepción de presiones políticas sobre el servicio audiovisual público y la evaluación de Media Pluralism Monitor, un proyecto de investigación de varias Universidades europeas coordinado por Centre for Media Pluralism and Media Freedom (CMPF) de European University de Florencia.

Según la opinión de los ciudadanos consultados por el Eurobarómetro Special 452 (2016), los países que están a la cola en nivel de independencia del servicio audiovisual público, por debajo del $33 \%$ de la valoración de los ciudadanos, son los siguientes: Grecia, 9\%; Francia, 16\%; España, 20\%; Chipre, 21; Malta, 24\%; Letonia, 24\%; Hungría, 30; e Italia, 33\%. Encabezan el ranking en respeto a la independencia y libertad frente a las presiones políticas de los medios audiovisuales de comunicación públicos estos otros países: Finlandia, 65\%; Eslovaquia, $55 \%$; Países Bajos, 55\%; Suecia, 55\%; Dinamarca, 54\%; y Alemania, $50 \%$.

La metodología del Eurobarómetro, de carácter cuantitativo, y la de Media Pluralism Monitor, de tipo cualitativo, son diferentes pero complementarias, coincidentes en resultados, salvo en un par de países. 
Encabezan el riesgo alto para la independencia del servicio audiovisual público los siguientes: Hungría, 92\%; Rumanía, 92\%; Chipre, 92; Eslovenia, 83; España, 83; Polonia, 83; Malta, 75\%; Italia, 75\%; Grecia, 67; y Finlandia, 67\%. Los países con bajo nivel de presión política sobre el sistema audiovisual público, según Media Pluralism Monitor, son: Bélgica, 3; Países Bajos, 3\%; Suecia, $3 \%$; Francia, 3\%; Alemania, 8\%; Reino Unido, 8\%; Lituania, 8\%; y Dinamarca, 8\%. Los datos contradictorios entre los dos indicadores son los de Finlandia y Francia, el primero considerado con altas presiones políticas y el segundo justamente lo contrario, según Media Pluralism Monitor, a diferencia de la percepción marcada por el Eurobarómetro.

5. Tipología acosada por partidos y fuerzas políticas populistas. La campaña de confrontación con la prensa del candidato primero y luego presidente de los Estados Unidos, Donald Trump, se ha reproducido por parte de algunos líderes y partidos políticos populistas europeos frente a los medios de comunicación públicos. El arma alternativa de confrontación son las redes sociales digitales, usadas como caldo de cultivo de las fake news y como instrumento de crítica para atacar la credibilidad de periodistas independientes y medios audiovisuales públicos influyentes en Austria, Eslovaquia, Polonia, Hungría, Alemania y República Checa.

Más de 16.000 firmas de ciudadanos checos registraron una petición al Senado de ese país para proteger sus medios audiovisuales de comunicación públicos. Las noticias relacionadas con la mafia y el gobierno eslovaco en el caso del asesinato del periodista Jan Kuciak provocaron censura y supresión de programas de investigación en la RTVS, con críticas y protestas por parte de los periodistas y la opinión pública independiente de dicho país.

El presidente checo, Milos Zeman, se llegó a presentar provocadoramente, en actos públicos frente a la prensa, con un simulacro de rifle Ak-47 y calificando a los profesionales de la información como "prostitutas" o "idiotas seguros de sí mismos". En Austria, la dirección de la ORF y uno de sus principales presentadores del programa informativo estrella denunciaron ante los tribunales a Heinz-Christian Stache, líder del partido de extrema derecha FPÖ y vicecanciller de la coalición gobernante, por acusar con fake news en 
Facebook al reportero y a la emisora pública de manipulación informativa. Alternativa para Alemania (AfD) también critica duramente a la ARD y la ZDF a la vez que propone una drástica reducción en su financiación.

\section{Legitimidad, innovación y sostenibilidad}

Enfrentado a críticas fundadas o extremas, algunas de ellas incluso llamativamente estrambóticas, el servicio audiovisual público en Europa -donde nació hace cerca de 100 años, que cumplirá la BBC en 2022, la primera corporación de este tipo del mundo- necesita afrontar los retos y cambios necesarios que fortalezcan el refuerzo o la renovación de su legitimidad en el contexto de la nueva sociedad digital.

En la sociedad moderna actual la legitimidad del servicio audiovisual público no se puede sostener solo con la legalidad de su regulación institucional, sino que precisa más que nunca del reconocimiento, reputación y credibilidad de su valor social. Para ello tiene que ser útil y conseguir el respaldo de la sociedad, de tal forma que su valor social público prevalezca sobre los intereses bastardos de quienes quieran manipularla o despreciarla porque no es afín a sus intereses particulares, sean estos políticos, comerciales, sindicales $\mathrm{O}$ profesionales.

En la campaña del "no billag" de marzo de 2018 (contra la licencia de pago del servicio audiovisual público) la SRG-SSR fue capaz de ganarse la opinión de la mayoría de los suizos que reconocieron su valor social y se impusieron a los que propugnaban la supresión de la contribución y, por lo tanto, de su desaparición. Ese referéndum sirvió para renovar la legitimidad de la financiación de la radiotelevisión pública suiza frente a sus populistas detractores.

La legitimidad y sostenibilidad del servicio audiovisual será reforzada cuando la sociedad que contribuye a su financiación -bien a través del pago de una contribución directa o de una subvención programada dentro del capítulo presupuestario de la administración pública- valore satisfactoriamente tanto su rendimiento como eficiencia y no ponga en cuestión su rentabilidad social. Esa es la orientación estratégica de aquellas corporaciones que se financian directamente mediante el canon de los usuarios: procurar satisfacerles para seguir mereciendo el 
pago de su contribución. Y debiera ser también la prioridad de las que reciben los fondos de los presupuestos del estado, porque son los ciudadanos los que al fin y al cabo contribuyen a la financiación con sus impuestos.

El refuerzo de la legitimidad pasa de igual manera por despejar la gobernanza no sólo de las relaciones y presiones políticas sino también por una rendición de cuentas más directa y horizontal, basada en la transparencia, participación e interacción con las diversas sensibilidades de cada sociedad. Este reto no depende solo de la capacidad y voluntad de auto regeneración del propio servicio audiovisual público sino de la convicción política e institucional de cada sociedad sobre su utilidad.

El servicio audiovisual público es una herramienta útil de la sociedad y las naciones tanto frente a la desinformación y a la manipulación de las fake news como al creciente dominio comercial y cultural de las plataformas globales sobre los mercados locales. Pero necesita comunicar mejor su utilidad con nuevas narrativas y liderar la alfabetización digital frente a las fake news. Tiene que impulsar la innovación para ser capaz de convertirse en un nodo lo más completo posible de información y comunicación pública en la nube, una metáfora que sirve para definir la difusión y el acceso universal a los servicios a través de Internet. Junto a la innovación, son valores esenciales del servicio audiovisual público la calidad, la diversidad, la universalidad y la rendición de cuentas.

La universalidad es uno de los valores esenciales del servicio público, tradicionalmente sostenida mediante la difusión digital terrestre, pero ahora orientada hacia Internet, mediante ofertas convergentes multimedia, multipantalla y multiservicios que permitan potenciar la fortaleza de su identidad basada en la singularidad de su proximidad para el ecosistema global.

Esa es la estrategia que están adoptando las principales corporaciones europeas de medios audiovisuales públicos: innovar para atender la universalidad a través de diversidad de canales y servicios desde la nube para cohesionar una respuesta a la fragmentación de los consumos. Haciéndolo directamente o mediante alianzas entre radiodifusores públicos (unión de France TV, RAI y ZDF para coproducciones 
europeas) y con operadores privados (de BBC, Channel 4 e ITV en Project Kangaroo o de RTVE, Mediaset y Atresmedia en la plataforma híbrida Lovestv) para enfrentarse a la penetración global de sus mercados por parte de Netflix y Amazon.

Pero la innovación del audiovisual público no sólo es una cuestión de oferta y servicio -pese a que eso es lo fundamental de cara a la sociedad- sino también de estructura, organización y gobernanza. Sus estructuras, infraestructuras, organización de recursos humanos y sistemas de gobernanza responden a rígidos esquemas del siglo pasado que difícilmente pueden adaptarse a la flexibilidad que exigen las nuevas formas producción, creatividad y talento con las que hay prestar un nuevo servicio público que sea reconocido por su valor social diferencial del que ofrece la competencia privada.

\section{Referencias bibliográficas}

Casetti, F. y Odin, R. (1990). De la paléo á la neo-télévision. Communications, 51, 10-24.

Crusafon, C. (2013). The Shutdown of the Public Regional Television in Valencia: The First Step Towards the End of Regional Public Service Broadcasting in Spain. Media Policy Project Blog LSE. Recuperado de http://blogs.lse.ac.uk/mediapolicyproject/2013/11/21/theshutdown-of-the-public-regional-television-in-valencia-the-firststep-towards-the-end-of-regional-public-service-broadcastingin-spain/.

Eco, U. (1986). Televisión: la transparencia perdida, la estrategia de la ilusión. Barcelona: Lumen.

Eurobarómetro (2016). Media pluralism and democracy. Special Eurobarometer 452, TNS. Recuperado de http://ec.europa.eu/information society/newsroom/image/do cument/2016-47/sp452-summary en 19666.pdf.

Evens, T.; Donders, K. (2018). Platform Power and Policy in Transforming Television Markets. Palgrave Macmillan. 
Hallin, D.C. y Mancini, P. (2004). Comparing Media Systems: Three Models of Media and Politics. Cambridge: University Press.

Hallin, D.C. y Mancini, P. (2011). Sistemas mediáticos comparados: tres modelos de relación entre los medios de comunicación y la politica. Barcelona: Hacer.

Lange, A. (2011). Converge et diversité des systèmes européens. En Paracuellos, J.Ch. y Benghozi, P.J. (2011), Télévision l'ere du numérique. París: La Documentation Française.

Le Diberder, A. y Coste-Cerdan, N. (1988): Briser les chaines: Introduction à l'aprételevision. París: La Découverte.

Mani Redondo, P. (2017). Evaluación y análisis del "media policymaking" de la reforma socialista del sector audiovisual y la Ley General de la Comunicación Audiovisual (2004-2011). Universidad Autónoma de Barcelona: tesis doctoral dirigida por el Dr. Carles Llorens Maluquer.

Missika, J.-L. (2006). La fin de la télévision. París: Seuil.

Nielsen, R. K. y Linnebank, G. (2011). Public Support for the Media: A Six-Country Overview of Direct and Indirect Subsidies. Oxford University: Reuters Institute for the Study of Journalism.

Pastoriza, F. R. (1997). Perversiones televisivas. Madrid: IORTV.

Piscitelli, A. (1999). Post- televisión: ecología de los medios en la era de Internet. Barcelona: Paidós.

Ramoned, I. (2002). La post-televisión. Multimedia, Internet y globalización económica. Barcelona: Icaria.

Tambini, D. (2016). Can the new Charter Protect BBC Independence? Media Policy Project Blog LSE. Recuperado de http://blogs.lse.ac.uk/mediapolicyproject/2016/01/27/canthe-new-charter-protect-bbc-independence/.

Tous Rovirosa, A. (2009). Paleotelevisión, neotelevisión y metatelevisión en las series dramáticas estadounidenses. Comunicar, 33, 175-183.

Vanhaeght, A.S. y Donders, K. (2015). Do interaction, co-creation and participation find their way from PSM literature to PSM 
policy and strategy? A comparative case study analysis of Flanders, the Netherlands, France and the UK. Medijske Stududije, 6(12), 46-61.

\section{Reconocimientos de investigación}

- Los resultados de este artículo corresponden al proyecto de "Indicadores de gobernanza, financiación, rendición de cuentas, innovación, calidad y servicio público de las RTV europeas aplicables a España en el contexto digital" (Referencia CSO2015-66543-P) del Programa estatal de Fomento de la Investigación Científica y Técnica de Excelencia, subprograma estatal de Generación de Conocimiento del Ministerio de Economía y Competitividad de España, cofinanciado por el Fondo Europeo de Desarrollo Regional (FEDER) de la Unión Europea. Así como de la actividad de la Red Internacional de Investigación de Gestión de la Comunicación (REDES 2016 G-1641 XESCOM) apoyada por la Consellería de Cultura, Educación e Ordenación Universitaria de la Xunta de Galicia (referencia ED341D R2016/019). 



\title{
La regulación de los debates electorales en el servicio audiovisual público
}

\author{
José Rúas-Araújo \\ José Fernández-Holgado \\ José Ángel Alén-Amil \\ Universidade de Vigo
}

PARA CITAR: Rúas-Araujo, J., Fernández-Holgado, J. y Alén-Amil, J.A. (2018). La regulación de los debates electorales en el servicio audiovisual público. En Pérez-Seijo, S., Rodríguez-Castro, M. y Túñez-López, M. (Eds.), Debates sobre valores e indicadores del servicio audiovisual público en Europa (pp. 79-96). Cuadernos Artesanos de Comunicación, cac142. La Laguna (Tenerife): Latina. DOI: $10.4185 / \operatorname{cac} 142$

\section{Resumen}

La reciente celebración de las elecciones en Cataluña, con la intervención de la autonomía por parte del Estado, al amparo del artículo 155 de la Constitución, ha puesto de manifiesto la necesidad de profundizar en la regulación y papel de las televisiones públicas, estatal y autonómica, ante conflictos de este tipo, con el artículo 20 de la Constitución y el debate sobre los límites de la libertad de expresión de fondo, en medio de un enfrentamiento cruzado entra las denominadas formaciones constitucionalistas e independentistas, entre recursos ante la Junta Electoral Central (JEC) y acusaciones de manipulación política de los canales públicos de televisión. Este trabajo describe la regulación de los procesos electorales y debates televisados 
por las distintas entidades y organismos reguladores de las televisiones públicas en Europa, con especial referencia al OFCOM del Reino Unido, como modelo y servicio a seguir, y defiende la necesidad urgente de profundizar en la regulación audiovisual y las garantías democráticas de los distintos procesos electorales y debates celebrados en España, incluyendo la presencia de las televisiones públicas en las redes sociales.

Palabras clave: regulación audiovisual, televisiones públicas, política, elecciones, debates.

\section{La regulación de las elecciones y los debates televisados: nuevas cuestiones sobre la mesa}

Un aspecto importante a tener en cuenta en la organización de los debates son las normas y reglas que los regulan en cada país, a través de distintos organismos reguladores, como ocurre con la Office of Communications (OFCOM) en el Reino Unido, el Conseil Supérieur de l'Audiovisuel (CSA) en Francia, la Entidade Reguladora para la Comunicaçao social (ERC) en Portugal o la Autoritá per le garanzie nelle comunicazioni (AGCOM) de Italia, todos ellos coordinados, a nivel supranacional, a través de la European Platform of Regulatory Authorities (EPRA).

La EPRA es un foro de colaboración entre autoridades que regulan el audiovisual cuyos principales objetivos son el intercambio de opiniones e informaciones y el debate de problemas y soluciones acerca de la regulación del audiovisual1 y dentro del cual también participan, como observadores permanentes, el Consejo de Europa, la Comisión Europea, el Observatorio Europeo del Audiovisual y la representación de la Organización para la Seguridad y la Cooperación en Europa (OSCE) para la libertad de los medios.

Tras la Federal Communications Commision (FCC) estadounidente, creada en 1934, el OFCOM es el referente a nivel europeo en cuanto a modelo e independencia, heredero de la tradición de servicio público de la British Broadcasting Corporation (BBC). En el caso concreto de OFCOM,

\footnotetext{
${ }^{1}$ https://www.epra.org/
} 
además del cumplimiento de una Carta y Código de Radiodifusión, la ley exige que la BBC adopte un código y guía de buenas prácticas editoriales (Editorial Guidelines) para regular la participación de los candidatos en cada circunscripción, con consideraciones específicas en materia electoral ${ }^{2}$.

Asimismo, el Chief Adviser Politics es el órgano encargado de elaborar las directrices específicas para la cobertura de las campañas electorales, tanto en televisión y radio como en medios online, incluyendo los distintos foros de discusión acordados por la BBC Trust. De hecho, cuando los contenidos de la $\mathrm{BBC}$ se transmiten a otros países, el canal mantiene sus principios editoriales, a través de $B B C W$ orld Service, $B B C$ $W$ orld y $B B C$ Online, incluso cuando la emisora local se niega a transmitir el contenido o servicio.

Además, en su Editorial Guidelines, la $B B C$ destaca que al disponer de producción en todo el Reino Unido "somos conscientes de las diferentes estructuras políticas en las cuatro naciones del Reino Unido y de que se reflejan en la cobertura electoral de cada nación", por lo que el modo en que se logra la debida imparcialidad entre las partes variará, dependiendo del formato, el producto y la plataforma, si bien este principio de imparcialidad afectará a todos los resultados de la cadena en todos los territorios.

Este modelo televisivo entronca con las teorías de la función social de la televisión como servicio de interés general y público y la defensa de una política mediática activa y fortalecedora de la relación entre emisor y receptor, aprovechando los nuevos recursos digitales (Horowitz, 2015; Tremblay, 2016; Trappel, 2016; Marzal y Zallo, 2016), y supone una referencia y base para el análisis de los distintos modelos y sistemas de relación entre los medios de comunicación y la política (Hallin y Mancini, 2008).

Aspectos como la mejora del pluralismo en las políticas mediáticas de la Comisión Europea (Costache y Llorens, 2015) o el análisis del futuro de las televisiones públicas en el seno del Comité de Regiones y el

2 http://www.bbc.co.uk/editorialguidelines/guidelines/impartiality/electionsand-referendums 
cumplimiento de los objetivos de gobernanza, así como la mejora en el acceso a los contenidos, la rendición de cuentas y el fomento de la participación ciudadana y de la ciudadanía activa, figuran entre las nuevas prioridades, a la hora de organizar, también, debates electorales (Muñoz y Azurmendi, 2016; Almiron, Narberhaus y Mauri, 2016; López, Puentes y Rúas, 2017).

Aun así, de fondo permanece la cuestión de si los debates son un simple programa de televisión en lugar de una institución democrática, consideraciones sobre las que existe cierto consenso legal en países como Alemania, a favor de la primera postura, aunque no exenta de planteamientos cada vez más discrepantes, sobre todo ante el auge de formaciones ultranacionalistas y extremistas.

En cualquier caso, siempre hay decisiones polémicas que deben tomarse sobre la organización de debates electorales televisados, como ocurrió en los últimos procesos electorales celebrados en el Reino Unido, sobre la participación e inclusión de candidatos, debido al incremento de la fragmentación electoral, como consecuencia de la entrada en escena del United Kingdom Independence Party (UKIP), o el interés nacional sobre la inclusión en los debates de formaciones como el Partido Nacional Escocés (SNP), bajo el argumento de que los partidos separatistas, por su propia naturaleza, plantean cuestiones que influyen a todos los ciudadanos de un estado y, en consecuencia, no pueden considerarse como de interés periférico (Anstead, 2015). Algo similar a lo ocurrido, recientemente, con las elecciones catalanas celebradas el pasado 21 de diciembre, con tres debates televisados, celebrados tanto a través del canal autonómico TV3 como, a nivel nacional, por la televisión pública TVE y el canal privado La Sexta.

En líneas generales, los tribunales se han negado a intervenir en la organización de debates televisados, dejando esta competencia para los organismos de radiodifusión y partidos políticos. Sin embargo, esto no significa que las entidades que organizan debates no tengan que rendir cuentas, tal y como destaca el Observatorio Europeo del Audiovisual en su último informe (2017).

Durante los años 2016 y 2017, se celebraron elecciones y referéndums en más de la mitad de los estados miembros del Consejo de Europa y, 
en el seno de la UE, existe cierta preocupación, en la actualidad, por un par de cuestiones básicas.

En primer lugar, está la posibilidad de imposición de reglas adicionales sobre la cobertura de las elecciones y organización de debates electorales en los medios o las posibles restricciones a la libertad de expresión y su control por parte del Tribunal Europeo de Derechos Humanos y, en segundo, la regulación de la utilización de los medios online en campaña, ante su creciente influencia y el notable incremento de la publicidad política por esta vía, aspectos sobre el que se pronunciaron varios organismos europeos, como la Asamblea Parlamentaria del Consejo de Europa.

En el caso de España, son los poderes públicos los encargados de regular los debates electorales, a partir de la consideración, desde la propia Constitución Española, de que el Estado tiene competencia exclusiva con respecto a las normas básicas relativas a la organización de la prensa, la radio y la televisión y, en general, a todos los medios de comunicación social, sin perjuicio de los poderes conferidos a las Comunidades Autónomas que se relacionan con su elaboración y ejecución (artículo 149.27). La Constitución también señala, en su artículo 1, la defensa del pluralismo político como un valor superior de su ordenamiento jurídico y establece que la ley regulará la organización y el control parlamentario de los medios de comunicación social dependientes del Estado o de cualquier ente público y garantizará el acceso a dichos medios de los grupos sociales y políticos significativos, respetando el pluralismo de la sociedad y de las diversas lenguas de España (artículo 20.3).

Por su parte, la Ley Orgánica de Régimen Electoral General (LOREG), es la encargada de establecer las reglas generales aplicables a todos los medios durante la celebración de las elecciones. De acuerdo con el artículo 66.1 de la LOREG, los medios de servicio público se comprometen a respetar el pluralismo político y social, así como la igualdad, proporcionalidad y neutralidad de la información en su programación durante el período de elección. En su declaración 4/2011 (modificada por la Instrucción 1/2015), la Junta Electoral Central (en adelante, JEC), explica con más detalle las obligaciones del compromiso de los medios de respetar, en época de elecciones, los principios de pluralismo, de igualdad, proporcionalidad y neutralidad 
de la información. Además, la JEC es la autoridad responsable de vigilar por el cumplimiento de las normas y dirimir los desacuerdos o recursos presentados por parte de los distintos partidos y candidatos electorales.

Durante la convocatoria de elecciones, a las cadenas de televisión se les exige no sólo respetar el pluralismo político y la igualdad, sino también la proporcionalidad y neutralidad en la programación informativa (artículo 66 LOREG e Instrucción 4/2011 de la JEC). De hecho, el respeto al pluralismo político es un mandato impuesto a los medios de comunicación públicos en la propia Constitución (artículo 20.3), exigencia reiterada durante el proceso electoral, durante el cual se debe garantizar la igualdad en el acceso a los cargos públicos, a través de la proporcionalidad en el reparto de tiempo disponible para cada formación en el acceso a los medios públicos y espacios destinados a publicidad electoral, en función de los resultados obtenidos en las últimas elecciones equivalentes celebradas. A estos preceptos de la Carta Magna se añade también el derecho de la sociedad a recibir información (García-Llovet: 1987).

Asimismo, los medios públicos deben respetar el principio de neutralidad informativa, como uno de los principios inspiradores de su actividad, de acuerdo con la Ley 17/2006 de la Radio y de la Televisión de Titularidad Estatal, para cuyo cumplimiento y garantía se establece un control preventivo que obliga a poner en conocimiento de las juntas electorales correspondientes, con la debida antelación, los "Planes de Cobertura Informativa de la campaña electoral", dentro de los cuales se incluyen los debates, entrevistas y programas específicos de naturaleza electoral que pretendan realizar, así como los criterios sobre la información relativa a la campaña electoral (Instrucción 4/2011).

Sin embargo, la JEC también ha diferenciado el tratamiento de la información política de carácter general o la información específica sobre elecciones, quedando fuera los programas de entretenimiento, a los que no son de aplicación los principios de neutralidad y proporcionalidad (Holgado-González, 2017), tal y como puso de manifiesto este órgano, a raíz que los recursos presentados por la formación UPyD sobre programas a los que no se les había invitado, concretamente, en el caso de "El Hormiguero" y "En tu casa o en la 
mía" (Acuerdos de la JEC 571/2015 y 568/2015, de 9 de diciembre, respectivamente).

En España las leyes "guardan un absoluto silencio", en palabras de Holgado-González (2017), sobre la regulación de los debates electorales televisados, pese a las reclamaciones de intervención en este sentido, en cuanto a su regulación y celebración (Solozábal-Echavarría, 1993).

Una ausencia de cobertura legal que hace que los debates electorales dependan, exclusivamente, de la voluntad de los candidatos. No hay obligación ni prohibición de celebrar debates electorales y, en caso de querer realizarlos, el único requisito es comunicarlo, previamente, a la JEC, con cinco días de antelación, indicando la fecha, hora e intervinientes (Instrucción de la JEC de 13 de septiembre de 1999), y los medios de comunicación, tanto públicos como privados, gozan de libertad para optar por el formato que prefieran, de acuerdo con los intervinientes.

\section{Las televisiones en las redes sociales}

En España, la regulación de debates electorales tampoco tiene en cuenta el uso y alcance de las comunicaciones a través de internet y las redes sociales, ni la participación de los candidatos a través de las mismas.

La irrupción de las segundas pantallas reabre un debate sobre el papel de las nuevas plataformas y redes sociales, acorde con los requerimientos básicos de la gobernanza de los medios de servicio público en Europa, dentro de cuyos principios se encuentra el fortalecimiento del debate y pluralismo democrático, la libre expresión de opiniones y la participación de las audiencias.

Nuevas oportunidades, nuevos medios y modos de participación y movilización a través de las redes sociales que desde la Unión Europea se consideran fundamentales, en relación con el bajo compromiso cívico y participación ciudadana y el fomento de la implicación política en el seno de los países comunitarios (De Vreese, 2014).

Una preocupación que, sin duda, constituirá un elemento fundamental de discusión de cara a las próximas elecciones europeas y sobre el que ya se han pronunciado algunos organismos reguladores de 
radiodifusión, como la Broadcasting Authority de Irlanda (BAI), cuyos poderes estatutarios, aunque no se extienden a la forma en que las televisiones utilizan las redes sociales, sí que menciona la necesidad de los canales dependientes de este organismo de implementar medidas para garantizar que sus referencias en las redes sociales sean precisas, justas, objetivas e imparciales.

Principios de fomento del debate, el pluralismo y la participación de las audiencias que están también presentes en la Ley de la Radio y la Televisión de Titularidad Estatal de 2006, que atribuye a RTVE esta gestión y, asimismo, abren un debate sobre la revisión pendiente de la Ley 7/2010 General Audiovisual de España, ante la exigencia de hacer uso de las nuevas tecnologías para ofertar nuevos servicios interactivos audiovisuales, con la intención de llegar a nuevos públicos.

El propio "Modelo para un tiempo nuevo" de reforma de la TV pública planteado en 2015 por el equipo coordinado por el catedrático de comunicación audiovisual Enrique Bustamante al gobierno socialista de Rodríguez Zapatero, mencionaba la existencia de numerosos documentos internacionales de la Unión Europea, el Consejo de Europa y la UNESCO, referidos a la profunda necesidad de adaptación del servicio público a la nueva era digital, para mantener sus misiones y peso relativo ante las nuevas demandas y necesidades sociales, sin lo cual el servicio público iría perdiendo influencia social hasta su extinción. Una evolución desde los servicios públicos de radiotelevisión (PSB, Public System Broadcasting) a los servicios públicos multimedia (PSM, Public System Media) y, en definitiva, del consumo lineal, propio de la programación tradicional, a la denominada televisión social e interactiva, como el entorno más adecuado para el desarrollo de un terreno cívico común (civic commons) en el que los ciudadanos puedan enlazar y compartir contenidos y fuera de la lógica comercial de Internet.

De fondo, permanece la cuestión de si los debates son un simple programa de televisión en lugar de una institución democrática y, sobre todo, la necesidad de dar respuesta a las nuevas exigencias y demandas ciudadanas de una participación activa, al amparo de la propia normativa expuesta anteriormente. Frente al modelo de comunicaciónmercado, que considera a las audiencias como meros instrumentos tecnológicos al servicio del laisser faire comunicativo y la denominada 
economía de la escucha, surge la reclamación de los derechos de las audiencias electrónicas, en ocasiones frenados por procesos de contrarreforma comunicativa y presión mediático-empresarial (Esteinou, 2017), por parte de los estados.

\section{El conflicto con Cataluña}

En el caso de los órganos de audiovisuales de España, los consejos autonómicos audiovisuales de Cataluña y Andalucía también forman parte de la EPRA, al igual que la Comisión Nacional de los Mercados y la Competencia.

Pero la mayor polémica, motivada por la falta de regulación y conflicto de competencias, se produjo a raíz de la aplicación del artículo 155 de la Constitución y la intervención, por parte del Estado, de la Comunidad Autónoma de Cataluña, con motivo de sus últimas elecciones autonómicas.

La LOREG señala que cuando las elecciones se llevan a cabo sólo en la asamblea legislativa de una Comunidad Autónoma, las funciones con respecto a los medios de comunicación de servicio público se limitan al territorio de la Comunidad Autónoma y deben ser ejercidos por la Comisión Electoral de esa comunidad autónoma o, si no está constituida, por la Comisión Electoral de la provincia cuya capital corresponde al de la Comunidad. En este caso, la Comisión Electoral de esta Comunidad Autónoma también tiene, al menos, los poderes que ejerce la Comisión Electoral Central, incluidos los relativos a la gestión de una Comisión de Radio y Televisión (en caso de que así se haga) por la legislación de la Comunidad Autónoma, que regula las elecciones a las respectivas Asambleas Legislativas3.

Sin embargo, en el caso de las elecciones autonómicas celebradas en Cataluña el pasado 21 de diciembre, el problema se suscitó ante el hecho de que esta autonomía carece de una ley electoral propia y, por ende, no dispone de una junta electoral autonómica, ya que nunca ha habido quórum entre los partidos a la hora de legislar sobre la materia

${ }^{3}$ Epígrafe específico de análisis del caso de España (Cabrera-Blázquez, F.C., 2017: 47), dentro del mencionado informe del Observatorio Europeo del Audiovisual. 
y la ley electoral catalana requiere una mayoría de dos tercios para ser aprobada y, en consecuencia, es la Junta Provincial de Barcelona la que ejerce como tal. Además, se suscitó otro problema de fondo sobre si el alcance de la intervención de la autonomía, a raíz de la aplicación del 155, debería incluir también a TV3 y Catalunya Radio, al considerar ambos medios como parte del engranaje propagandístico independentista, una posibilidad que llegó a barajar el gobierno del entonces presidente, Mariano Rajoy.

Estas circunstancias provocaron un contexto de tensión y polarización añadida, ante el papel protagonista de la JEC y las juntas zonales, debido a las circunstancias excepcionales y las denuncias cruzadas por la supuesta vulneración de los principios de igualdad, neutralidad y pluralismo informativo, por parte de las televisiones y radios, autonómicas y estatal. Continuos vituperios e interrupciones entre los siete candidatos en liza fueron las constantes de los distintos debates celebrados en la última semana de campaña, tanto en La Sexta como en TV3.

Cuestiones como la decisión de la JEC y las juntas locales de prohibir iluminar fuentes y edificios públicos de amarillo o llevar lazos amarillos en la solapa, o la petición a los medios públicos de la Corporació Catalana de Mitjans Audiovisuals (CCMA) de evitar determinadas expresiones como "consellers encarcelados" o "Govern en el exilio" quedaron desautorizadas en la práctica, con la celebración de los debates en La Sexta y TV 3 , donde los candidatos independentistas incluso llegaron a referirse al "golpe de Estado" a Cataluña y posaron con lazos amarillos y camiseta amarilla (en el caso de la candidata de ERC, Marta Rovira, en el debate celebrado en TV 3 ), aparte de la polémica por la solicitud planteada por JxCAT a TV 3 de que Puigdemont participase en el debate desde Bruselas, a través de una pantalla de plasma, lo cual también provocó una petición similar para en el caso de ERC y Oriol Junqueras, desde la cárcel de Estremera (Madrid), para lo que se requería una autorización por parte del juez del Tribunal Supremo.

Todo ello mezclado con las acusaciones cruzadas, por parte de TVE y TV3, de falta de pluralismo en los debates y tertulias organizadas por ambas cadenas, con un marcado desequilibrio en el número de 
tertulianos a favor o en contra de la independencia ${ }^{4}$. Igualmente, las denuncias del Consejo de Informativos de TVE por cuestiones como la comparación del referéndum catalán con el celebrado meses antes en Venezuela o detalles como la utilización de la banda sonora de la película "El Exorcista" sobre la voz e imágenes de Carles Puigdemont, o las críticas a TV 3 por seguir utilizando el tratamiento de "President de la Generalitat" cuando Puigdemont ya había sido cesado, o la falta de neutralidad en programas de humor (Polónia) e incluso infantiles (Info $K)$.

Este panorama muestra la necesidad de profundizar, también, en la regulación de los debates electorales televisados celebrados en España, tanto en los canales públicos estatales y autonómicos como privados, que se debaten entre el conservadurismo de los primeros a la hora de organizar los debates -o conflictos de competencias, como se evidenció entre TVE y TV 3- y el intento de aperturismo y condiciones de los segundos, que además denuncian que las televisiones privadas tengan que someterse a cuotas de intervención y al cronómetro impuesto por políticos, sin contar con la opinión y de los medios y convirtiendo de este modo la información en propaganda, tal y como se denuncia desde la Unión de Televisiones Comerciales Asociadas (UTECA).

En este sentido, distintos colectivos de periodistas, como la Federación de Asociaciones de Periodistas de España (FAPE) ${ }^{5}$ o los Consejos de

${ }^{4} \mathrm{Al}$ respecto cabe recordar que, por ejemplo, la "Charte des Antennes" de France Television contempla que la elección de invitados en las tertulias televisivas debe hacerse "con vistas al pluralismo y el equilibrio de puntos de vista" y prestando "el mismo nivel de atención" a todos los invitados, por parte de los moderadores. Un aspecto sobre el que también se pronunció la Broadcasting Authority de Irlanda (BAI), con motivo del referéndum de la Octava Enmienda de la Constitución, al indicar que el equilibrio no se logra necesariamente con un enfoque de "cronómetro" en la asignación de tiempos de transmisión, sino también con el establecimiento de criterios de diversidad y equidad en las intervenciones y opiniones.

5 Escrito de la FAPE de 10 de febrero de 2011, dirigido a la Defensoría del Pueblo, solicitando que interpusiera un recurso de inconstitucionalidad contra la LO 2/2011 que imponía bloques de información electoral a las televisiones privadas, conforme a los resultados obtenidos en las anteriores elecciones. 
Informativos de $\mathrm{RTVE}^{6}$, han expresado su malestar por la imposición de criterios meramente cuantitativos, en cuanto a tiempos y orden de emisión, frente al criterio periodístico que debería determinar lo que es noticiable o no. Criterios cuantitativos que, además, pueden ser burlados, a través de diferentes tratamientos cualitativos y de contenido, favorables a una determinada candidatura sobre otra.

Un aspecto sobre el que también ha insistido el Colegio de Periodistas de Cataluña, que en el año 2005 presentó una demanda contra España ante el Tribunal Europeo de Derechos Humanos, finalmente desestimada, y que también motivó la reciente presentación de recursos por parte del Consell Professional de TV 3 al Tribunal de Estrasburgo, apelando a la libertad de expresión y reunión, recogida en los artículos 10 y 11 del Convenio Europeo de Derechos Humanos.

Tanto el Estatuto General de Radio Televisión Española como sus "Principios básicos y líneas de programación", entienden que la información debe ser objetiva, veraz e imparcial, lo cual exige tanto la separación expresa entre información y opinión, como que las distintas fuerzas políticas, sindicales, sociales, culturales y religiosas reciban un tratamiento equitativo. Además, el hecho de que RTVE se financie con dinero público y reciba ingresos del Estado (no existe un canon por hogar), condiciona la cobertura de actos oficiales -la denominada "cultura gubernamental" de la cadena- sea o no rentable esa cobertura.

Todo ello, aparte de la dependencia política del Consejo de Administración de RTVE y, en definitiva, su adhesión a la teoría clásica y rígida de objetividad (Rosen, 1994), condicionada por la búsqueda de un equilibrio matemático en la asignación de tiempos, frente a la nueva teoría de la objetividad, propuesta por la corriente americana Periodismo Público, que permite una cobertura más en sintonía con los intereses de la audiencia y menos dependiente de la imposición de reglas por parte de los políticos a los medios, que minan la autonomía profesional de los periodistas (Canel, 1997).

${ }^{6}$ En su escrito de 24 de mayo de 2016, los Consejos de Informativos de RTVE denuncian la manipulación y desequilibrio informativo en favor en el partido en el gobierno. 
La búsqueda de un equilibro político y la salvaguarda de los intereses y derechos de los ciudadanos frente a la intervención jurídica son, en definitiva, cuestiones que siguen estando en las mesas de debate sobre los debates.

\section{Discusión y conclusiones}

La creciente polarización y sesgo ante un conflicto de unión o división territorial, como el referéndum de Brexit del Reino Unido o la intervención de la autonomía de Cataluña, con opiniones y partes muy enfrentadas, repercute notablemente sobre la cobertura informativa por parte de los medios públicos en cada nación y territorio.

El último informe Reuter sobre confianza en los medios destaca una falta de confianza en los medios de todos los países, particularmente con motivo de la convocatoria de elecciones, situación que ha empeorado con la irrupción de las redes sociales, lo cual también se ha notado en medios públicos de referencia, como es el caso de la $B B C$, que encabezó el ranking de confianza y desconfianza, a partes iguales, entre partidarios y detractores del Brexit (Newman y Fletcher, 2017), pues los esfuerzos por ser imparciales por parte del canal público generaron una impresión de equivalencia falsa, con problemas de representación y parcialidad, reconocidos por parte de los periodistas. Una cobertura informativa que incluso provocó algún análisis crítico sobre el contenido de las noticias y resúmenes de prensa contenidos en la propia página web de la $B B C$ y sus programas dedicados a repasar los titulares y noticias de los diarios (Renton y Schlosberg, 2017).

Sin embargo, la existencia de un organismo regulador independiente con el OFCOM, la Carta y el Código de Radiodifusión y la existencia de una Guía Editorial (Editorial Guidelines) de la BBC, con un asesoramiento específico a través del Chief Adviser Politics, contribuye a compensar y corregir los posibles errores y desviaciones en la cobertura informativa de cada proceso electoral, con la publicación de directrices separadas para todas y cada una de las elecciones convocadas.

De hecho, OFCOM ha emitido notas y criterios específicos dirigidos a los periodistas y locutores, con motivo tanto del referéndum del Brexit, de junio de 2016, como de las elecciones generales celebradas un año después, en junio de 2017, así como directrices específicas para cada convocatoria o consulta electoral. En concreto, entre los últimos 
pronunciamientos del órgano regulador audiovisual británico se encuentran aspectos como que los candidatos a la elección no pueden aparecer como presentadores o entrevistadores de ningún tipo de programa durante el período electoral y no que se deben organizar encuentros o entrevistas con candidatos en programas que no sean políticos durante el período electoral. Además, ante cualquier que pudiera presentarse antes de la fecha de elección, Ofcom se comprometía a "actuar rápidamente para determinar y solucionar el problema de manera proporcionada y transparente" antes de que se produjera la votación (IRIS, 2017; OFCOM, 2017 a; 2017b).

Ofcom ofrece, en consecuencia, un servicio constante y activo, actual y adaptado a cada proceso electoral, hasta el punto de que incluso realiza estudios prospectivos y sondeos periódicos para evidenciar el apoyo pasado o actual de las distintas fuerzas políticas, con vistas a contemplar su posible cobertura en los distintos territorios, como ocurrió con motivo de las elecciones locales celebradas en el Reino Unido en mayo de 2018.

Y con respecto a la convocatoria de referéndums y las polémicas suscitadas ante los mismos, con opiniones siempre muy encontradas, sirva también como ejemplo y antecedente la regulación y directrices publicadas por la Broadcasting Authority of Ireland (BAI), con motivo de la reciente consulta sobre la Octava Enmienda de la Constitución, cuyo resultado fue la despenalización del aborto en Irlanda, y donde la BAI se preocupó con garantizar una pluralidad y equidad de voces y opiniones en sus emisoras.

Pero ejemplos e incidencias como las indicadas en este trabajo, con respecto a la cobertura por parte de RTVE y la radio y televisión autonómicas de Cataluña, muestran la necesidad de una urgente regulación, control y seguimiento específico de cada proceso electoral, con la aplicación de un modelo más ágil y eficaz, similar al aplicado por entidades reguladoras como OFCOM y BAI.

De hecho, con motivo a la convocatoria del referéndum catalán y de la decisión de la intervención de la autonomía al amparo del artículo 155 de la Constitución, una posibilidad inmediata, a falta de regulación específica, habría sido la constitución en el Senado, como cámara de representación territorial, de una comisión de control y seguimiento del 
TV3 y Catalunya Radio, de carácter plural e integrada por representantes de todas las fuerzas políticas.

De momento, tal y como señala Holgado-González (2017), la LOREG trata la cuestión de una forma bastante parca, centrada en la contratación de publicidad electoral y la regulación de espacios gratuitos de propaganda, ofreciendo una visión que se acerca más a la idea de consumidor que a la de ciudadano, al poner el acento en los medios de comunicación como instrumento o lugar para la propaganda política, más que en el contenido y calidad periodística de la información.

Un aspecto que, visto lo ocurrido en el caso de las recientes elecciones de Cataluña, también debería fijar su atención en toda la producción de los programas de las televisiones públicas implicadas, incluyendo los educativos y de entretenimiento, sobre los que, igualmente, se publicaron directrices por parte de los organismos reguladores europeos. Principios de formación, información y entretenimiento de las audiencias que también será necesario tener en cuenta, por parte de las televisiones públicas, nacionales y autonómicas, en cada una de las convocatorias electorales. Confiemos por tanto en que las reformas pendientes contemplen una regulación audiovisual adaptada a la realidad actual, a través de la constitución de un organismo independiente.

\section{Bibliografía}

Anstead, N. (2015). Social Media Analysis and Public Opinion: The 2010 UK General Election. Journal of Computer-Mediated Communication, 20, 204-220.

Almirón, N., Narberhaus, M. y Mauri, M. (2016). Mapping media accountability in stateless nations: The case of Catalonia. Catalan Journal of Communication \& Cultural Studies, 8(2), 207-225.

Canel, M.J. (1997). La objetividad periodística en campaña electoral: las actitudes profesionales de los periodistas de TVE1 y Antena3 en las elecciones de 1996. ZER. Revista de Estudios de Comunicación, 2, 55-70. 
Costache, A.M. y Llorens, C. (2015). A bridge too far? Analysis of the European Commission's new developments on media policy and media freedoms through the concept of soft regulation. International Journal of Media and Cultural Politics, 11(2), 165-182.

De Vreese, C. (2014). Reinforcement of Citizens Involvement and Participation. European Parliament. Strengthening European Democracy: Citizens' Participation. Which Challengues do we face at the European Elections of 2014? Dialogue with Churches and Non-Confessional Organisations. Directorate General For Internal Policies. European Parliament. Recuperado el 14 de junio de: file:///C:/Users/Propietario/Desktop/IPOLAFCO NT(2013)493036 EN.pdf

Esteinou, J. (2017). Los medios electrónicos. Anuario de Investigación de la Comunicación. CONEICC, XXIV, 31-52.

García Llovet, E. (1987). El derecho de antena y las campañas electorales", RDP, 25, 151-181.

Hallin, D. y Mancini, P. (2008). Sistemas mediáticos comparados. Tres modelos de relación entre los medios de comunicación y la política. Barcelona: Editorial Hacer.

Holgado-González, M. (2017). Publicidad e información sobre elecciones en los medios de comunicación durante la campaña electoral. Teoría y Realidad Constitucional, 40, 457-485.

Horowitz, M.A. (2015). Public Service Media and Challegue of Crossing Borders: Assessing New models. Medijske Studije, 6(12), 80-90.

IRIS (2017). Regulator issues note to broadcasters for upcoming general election". Recuperado el 12 de junio de:

http: $/ /$ merlin.obs.coe.int $/$ newsletter.php?year $=2017 \&$ issue $=6 \&$ iris ref $=2017+6+19$

López, P.C., Puentes, I. y Rúas, J. (2017). Transparencia en televisiones públicas: desarrollo de indicadores y análisis de los casos de España y Chile. Revista Latina de Comunicación Social, 72, 253-272. 
Marzal, J. y Zallo, R. (2016). Las televisiones públicas de proximidad ante los retos de la sociedad digital. Communication \& Society, $29(4), 1-7$.

Muñoz, M. y Azurmendi, A. (2016). El papel de las televisiones públicas autonómicas en el desarrollo de la gobernanza multinivel en Europa", Communication \& Society, 29(4), 45-58.

Newman, N. y Fletcher, R. (2017). Digital News Project. Audience Perspectives on Low Trust in the Media. Reuters Institute for the Study of Journalism. University of Oxford. Recuperado el 12 de junio de: https://reutersinstitute.politics.ox.ac.uk/risjreview/bias-bullshit-and-lies-audience-perspectives-low-trust$\underline{\text { media }}$

OFCOM (2017a). Note to broadcasters: Election programming.

Ofcom Broadcast On Demand Bulletin, Issue number 327, 24 april, p.5. Recuperado el 14 de junio de:

https://www.ofcom.org.uk/ data/assets/pdf file/0013/1012 27/Issue-327-of-Ofcoms-Broadcast-and-On-DemandBulletin.pdf

OFCOM (2017b). Ofcom's Rules on Due Impartiality, Due Accuracy, Elections and Referendums, 9 march. Recuperado el 14 de junio de:

https://www.ofcom.org.uk/ data/assets/pdf file/0030/9814 8/Due-impartiality-and-elections-statement.pdf

Renton, A. y Schlosberg, J. (2017). Stories and Guest Discussants of Newspaper Coverage, $18^{\text {th }}$ April to 21 May 2017. Recuperado el 14 de junio de: http://www.mediareform.org.uk/wpcontent/uploads/2017/06/BBC-NEWSPAPERS-REPORTFINAL.pdf

Rosen, J. (1994). Making Things More Public: On the Political Responsibility of the Media Intellectual. Critical Studies in Mass Communication, 11.

Solozábal-Echavarría, J.J. (1993). Una visión institucional del proceso electoral. REDC, 39 (67). 
Trappel, J. (2016). Taking the public service remit forward across the digital boundary. International Journal of Digital Television, 7(3), 273-295.

Tremblay, G. (2016). Public Service Media in the Age of Digital Networks. Canadian Journal of Communication, 41(4), 191-206. 


\title{
La reputación del servicio audiovisual público en la era post-tv. El caso RTVE
}

\author{
Carmen Costa-Sánchez \\ Universidade da Coruña
}

PARA CITAR: Costa-Sánchez, C. (2018). La reputación del servicio audiovisual público en la era post-tv. El caso RTVE. En Pérez-Seijo, S., Rodríguez-Castro, M. y Túñez-López, M. (Eds.), Debates sobre valores e indicadores del servicio audiovisual público en Europa (pp. 97-110). Cuadernos Artesanos de Comunicación, cac142. La Laguna (Tenerife): Latina. DOI: 10.4185/cac142

\section{Resumen}

La televisión afronta un contexto de cambios e incremento de la competencia. Para el medio público, la reputación se convierte en una importante aliada para salir victoriosa de la batalla de la credibilidad, de la referencialidad y la confianza. Pero sin confianza, no hay reputación. El círculo es eterno. El presente análisis reflexiona y aplica los tres principales condicionantes de la reputación (dimensión axiológica, comportamiento comprometido y proactividad reputacional) a RTVE. Las conclusiones apuntan a una dimensión axiológica fructífera en términos de códigos éticos y profesionales, pero insuficiente en el comportamiento corporativo, lo que desencadena en los ciudadanos el cuestionamiento de la confianza. La gestión reputacional, a falta de un análisis de documentos internos de planificación y estrategia, semeja más reactiva que proactiva.

Palabras clave: Televisión pública, reputación, España, post-tv, RTVE, imagen. 


\section{Cultura post-tv. Nuevas pantallas, nuevos actores, viejos desafíos}

Nos encontramos en un contexto de cambio acelerado y constante. Ello conlleva para la investigación en comunicación la necesidad de ser permanentemente observadora de lo que acontece para intentar capturar y analizar un presente que se desvanece y un futuro que es efímero. El establishment mediático, tal y como lo conocíamos, ve como sus cimientos se tambalean. Incluida la reina del consumo mediático. La televisión, hija predilecta de los hogares europeos, afronta un contexto de competitividad creciente, de consumo fragmentado, en el que la pantalla se adapta al usuario y no a la inversa.

"Nuevos productores, gigantes tecnológicos y otras compañías totalmente ajenas al negocio tradicional de la televisión Facebook, Amazon, Google, Apple o Snapchat, entre otrashan desembarcado o anunciado su llegada al mercado audiovisual para disputar el liderazgo del mercado a los radiodifusores clásicos" (Cerezo y Cerezo, 2017).

Las cifras de penetración del medio televisivo en España muestran una tendencia decreciente (AIMC, 2018). La competencia se ha incrementado en nuestro entorno dada la entrada de los canales de televisión en streaming, a los que se suman las plataformas, fundamentalmente, de cine a la carta. En relación a ello, los hábitos de consumo audiovisual son diversos. Así, la televisión convencional resulta aburrida para no pocos niños y adolescentes. No así Netflix o YouTube donde pueden encontrar los contenidos que desean (Gutiérrez, Islas y Arribas, 2018).

Ha caído el monopolio de la pantalla única. Cada ciudadano lleva su propia pantalla en el bolsillo en forma de smartphone para acceder a contenidos audiovisuales de su interés, cortos, compartibles, a su disposición en cualquier momento y lugar.

Los servicios audiovisuales públicos se enfrentan a desafíos que no son nuevos, pero sí van en aumento (Costa-Sánchez y Guarinos, 2018). La competencia había llegado a España ya a inicios de los 90's, y la multiplicación de la oferta derivada de la digitalización se había asentado a lo largo de los 2000. Sin embargo, en una nueva etapa más reciente, es Internet y las nuevas pantallas el nuevo escenario en el que 
se plantea una pugna por la atención de los usuarios, que cada vez se encuentran más empoderados en su rol de programadores de su propia dieta televisiva (Izquierdo-Castillo, 2014).

"La digitalización de los procesos, la atomización de las audiencias, la multiplicación de la oferta de libre acceso mediante la TDT y la consolidación de Internet y los nuevos medios como dispositivos de consumo conducen hacia una nueva etapa en la dinámica y el alcance de la televisión pública” (Manfredi, 2011:51).

$\mathrm{Al}$ incremento de la competencia y nuevos hábitos de consumo audiovisual, hay que añadir otros condicionantes que afectan a la televisión en su condición de servicio público. En primer lugar, como televisión pública, el servicio que prestan a los ciudadanos debe ir más allá del simple entretenimiento audiovisual, ofreciendo contenidos de calidad de tipo informativo, cultural y, por supuesto, también de entretenimiento.

En segundo lugar, debe ser aprobada por los ciudadanos en la medida en que también se financia con los presupuestos generales del Estado y se debe a la sociedad española en su conjunto.

Algunas medidas puestas en marcha en este sentido han sido la apuesta por la transparencia en aras de recuperar la confianza de una ciudadanía marcada por los recortes y las dificultades económicas (López López et al., 2017) o la necesidad de mejorar su reputación (Fernández y Campos, 2013).

La reputación de la televisión pública española es el eje vertebrador de la siguiente reflexión que pretende conocer en mayor profundidad los cuestionamientos acerca de su imagen para poder proponer algunas vías de trabajo y mejora aplicables a un futuro a corto plazo.

\section{El concepto de "reputación". Reflexiones aplicadas}

El concepto de reputación es un concepto multidimensional, que se sustenta en otros como los de imagen, confianza y calidad de las relaciones entre una organización y sus públicos. Se configura además como el objetivo final de la comunicación corporativa. Van Riel (1997: 26) define la comunicación corporativa como el instrumento de gestión por medio del que toda forma de comunicación interna y externa conscientemente utilizada, se armoniza de manera efectiva y eficaz para 
crear una base favorable para las relaciones con los públicos de los que la empresa depende. En la misma línea Cornelissen (2011:5) la considera una función de gestión que ofrece un marco adecuado para la efectiva coordinación de la comunicación interna y externa con el propósito de establecer una reputación positiva con respecto a los stakeholders. El objetivo es conseguir una adecuada reputación de la empresa y establecer relaciones de calidad continuas entre ella y sus públicos, en definitiva, conseguir la confianza de todos, argumenta Dircom (2013).

En relación a los conceptos de imagen y reputación, podemos distinguir dos escuelas o corrientes fundamentales:

1. Escuela análoga, según la cual, imagen y reputación son sinónimos. En esta línea se encuentran las reflexiones de autores como Capriotti. "La imagen o reputación se establece, fundamentalmente, como una estructura cognitiva de los públicos, como resultado del proceso interno del consumo de la información que realizan los individuos, que dará como resultado la estructura mental de la empresa" (Capriotti, 2006: 6).

2. Escuela diferenciada, según la que se trata de términos distintos, aunque están relacionados. "Reputación engloba a imagen y se convierte en un atributo que se genera cuando las expectativas de una organización se evalúan a través de sus acciones y de sus productos o servicios y los públicos trasladan ese enjuiciamiento de acciones pasadas a acciones futuras" explica Túñez (2012: 45). Xifra (2014) indica que la reputación expresa el grado de confianza que los públicos tienen en la capacidad de la persona natural o jurídica de respetar sus promesas y satisfacer las expectativas creadas.

Para Villafañe (2017), la reputación es el reconocimiento que hacen los grupos de interés del comportamiento y de la realidad corporativa en función del grado de satisfacción de las expectativas de aquellos.

Según Carreras, Alloza y Carreras (2013: 86), "reputation is a set of collective evaluations that is evoked in different audiences by the behaviour of a company and predispose the audiense toward support or resistance".

Del conjunto de aproximaciones revisadas - a este respecto, resulta de utilidad consultar Martínez y Olmedo (2010)- se desprenden como 
denominadores comunes una serie de elementos. En primer lugar, se trata de un intangible no controlable como tal por la organización, ya que se genera en los públicos. En segundo lugar, dicho intangible toma la forma de juicio de valor a respecto del comportamiento corporativo de una determinada entidad. En tercer lugar, desde una perspectiva temporal, se asume como creado/generado con el paso del tiempo y no como un reflejo coyuntural. En cuarto lugar, da lugar a comportamientos más o menos favorables o desfavorables hacia dicha organización, sus líderes, sus productos o sus servicios. De aquí su relación con los conceptos de credibilidad, responsabilidad o confianza.

En la argumentación de Villafañe (2004), la reputación se deriva de tres condiciones imprescindibles:

1. Una sólida dimensión axiológica.

2. Un comportamiento corporativo comprometido.

3. Proactividad en la gestión reputacional.

A continuación, se sintetizan algunos indicadores comprendidos en cada uno de estos vectores que conducen hacia la empresa reputada.

En cuanto a la dimensión axiológica, ésta incluiría los valores corporativos (valores éticos, valores relacionados con la ideología corporativa y aquellos relacionados con la orientación estratégica o valores profesionales), así como los códigos deontológicos, es decir, aquellas declaraciones normativas y de autorregulación.

En cuanto a la segunda condición, el comportamiento corporativo comprometido se lograría siempre que el estándar de dicho comportamiento supere la media del sector y que los compromisos sobre los que exista una declaración explícita se cumplan siempre y en cualquier circunstancia.

Algunos indicadores sobre la actitud proactiva se darían en: la existencia de una política formal de reputación corporativa; el establecimiento de objetivos operativos de reputación y los correspondientes planes de mejora y la eliminación de aquellos riesgos reputacionales que sean identificados. 
El presente trabajo parte de las tres condiciones sine qua non propuestas por Villafañe (2004) y las pone en relación con el comportamiento corporativo de la Corporación RTVE, para detectar así los vectores en los que se avanza o se debe mejorar con respecto a su gestión reputacional.

\section{La dimensión axiológica: Valores éticos y profesionales}

Los valores corporativos de RTVE vienen recogidos en la web de la entidad, donde se recoge textualmente que RTVE defiende y promociona en toda su programación los valores constitucionales, especialmente los de libertad, igualdad, pluralismo y tolerancia, sobre los que se asienta la convivencia democrática (sic). Ello resumiría su modo de hacer, la esencia de su cultura corporativa. Son valores, fundamentalmente, de tipo ético.

\section{Declaraciones normativas y de autorregulación (RTVE, 2018)}

\begin{tabular}{|l|l|}
\hline Nombre & Valores \\
\hline $\begin{array}{l}\text { Estatuto de la } \\
\text { información }\end{array}$ & $\begin{array}{l}\text { Rigor, independencia, neutralidad, } \\
\text { objetividad, veracidad, libertad, excelencia }\end{array}$ \\
\hline $\begin{array}{l}\text { Manual de estilo. } \\
\text { Directrices para } \\
\text { profesionales. }\end{array}$ & $\begin{array}{l}\text { Independencia, calidad y pluralidad de los } \\
\text { contenidos y la atención a los intereses de } \\
\text { toda la sociedad. }\end{array}$ \\
\hline $\begin{array}{l}\text { Código de } \\
\text { RTVErregulación de }\end{array}$ & $\begin{array}{l}\text { La dignidad de la persona, sus derechos, y el } \\
\text { libre desarrollo de su personalidad; el } \\
\text { principio de igualdad, sin que pueda } \\
\text { prevalecer discriminación alguna; el honor, la } \\
\text { intimidad personal y familiar y la propia } \\
\text { imagen; y también la protección de la } \\
\text { juventud y la infancia, de acuerdo con la } \\
\text { normativa vigente. }\end{array}$ \\
\hline $\begin{array}{l}\text { Principios básicos } \\
\text { de la programación }\end{array}$ & $\begin{array}{l}\text { Principios constitucionales, pluralismo, } \\
\text { objetividad, veracidad, debate, participación, } \\
\text { diversidad, cohesión, interés público, } \\
\text { producción cultural propia, integración social, } \\
\text { igualdad, calidad, innovación }\end{array}$ \\
\hline
\end{tabular}

Fuente: RTVE. Elaboración propia. 
A ellos habría que añadir lo que los anglosajones denominan work values, aquellos referidos a la orientación estratégica y de las funciones de la organización.

La existencia de los diversos códigos y normas de autorregulación resultan un indicador positivo y coherente con el contexto actual de búsqueda de transparencia y de justificación de su existencia y necesidad social. No todas las corporaciones estatales de radiotelevisión pública tienen libros de estilo o estándares similares de normas editoriales (Campos-Freire, Soengas-Pérez y RodríguezCastro, 2018).

Sin embargo, la existencia de dichas normas por escrito contrasta gravemente con algunos conflictos derivados del comportamiento corporativo de la entidad, como veremos al aplicar el segundo condicionante.

\section{El comportamiento corporativo y su nivel de compromiso}

Esta condición venía dada, siguiendo a Villafañe (2004), por dos elementos: que el estándar de ese comportamiento supere la media del sector y que aquellos compromisos sobre los que exista una declaración explícita se cumplan siempre y en cualquier circunstancia.

Tal y como ha trascendido a la opinión pública, diversos hechos se contraponen a la dimensión axiológica expresada por la propia Corporación. En concreto, se sintetizan a continuación algunos de estos hechos:

- Viernes de luto en RTVE. Los trabajadores de la entidad se vistieron de negro en pantalla y en las redes para protestar por el bloqueo político a respecto de la renovación de la cúpula de RTVE. En diversas convocatorias, profesionales de RTVE han dado a conocer su descontento a los ciudadanos, vistiéndose de luto y activando una importante campaña en redes y medios sociales. El Comité de Informativos de RTVE reclamaba así una televisión pública plural e imparcial. El contraste entre unas declaraciones de principios y unos códigos profesionales que parten de los valores de independencia y neutralidad se contrapone a un comportamiento corporativo que llega a los ciudadanos como poco transparente a este respecto. 


\section{C.Informativos TVE @Cdltve · Jun 9}

Aquí tenéis a todos los que este \#ViernesNegro7 han vestido de negro ante la cámara para reclamar una RTVE plural e imparcial. Ojalá este martes TODOS los partidos logren sacar adelante el reglamento para renovar la cúpula de \#RTVE \#RTVEdeTodasyTodos

(6) Translate Tweet

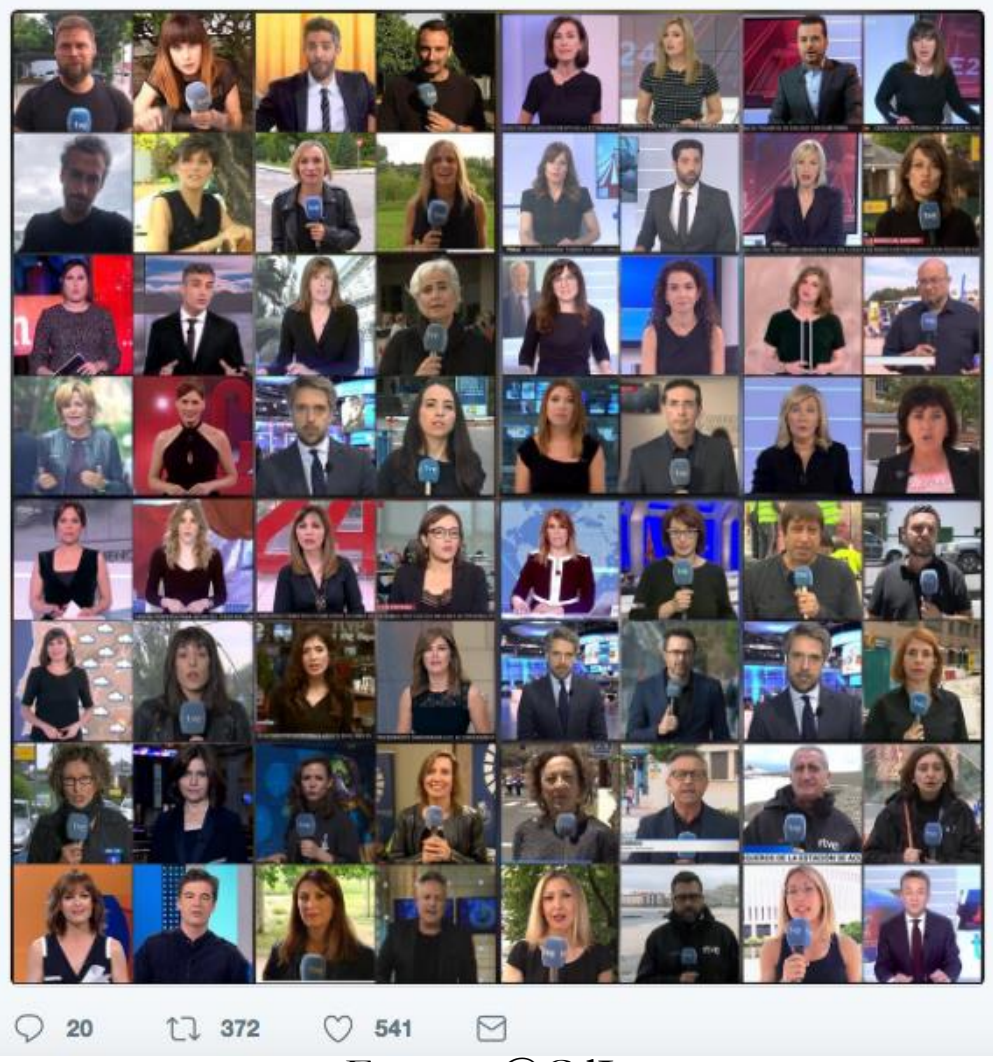

Fuente: @CdItve

- \#AsiSeManipula. Éste es el lema de la campaña iniciada por las trabajadoras de RTVE para denunciar un tratamiento sesgado de la información. A través de sus cuentas en Twitter e Instagram, la plataforma denuncia nuevamente la falta de independencia y de neutralidad en la gestión de la Corporación y la manipulación informativa. De nuevo, los stakeholders internos, es decir, los profesionales de RTVE llevan a cabo una campaña de employer accusation, de manera que la credibilidad de los propios trabajadores juega en contra de la percepción de la entidad por parte de los públicos externos.

Por otra parte, en el medio televisivo público, las expectativas creadas y la confianza generada se avalan en el respaldo de las audiencias a la apuesta programática de la cadena. En este sentido, el balance de audiencias español de 2017 (Barlovento, 2018) muestra que La1 ha sido la tercera opción de las audiencias en España por detrás de las dos 
principales cadenas privadas, Telecinco y Antena3. En el terreno de los informativos, La1 se ha disputado el liderazgo en informativos con Telecinco, lo que tampoco la consolida como claro referente en los hábitos informativos de la sociedad española.

Según el reciente estudio del Pew Research Center (2018), en comparación con otros países europeos, en España el liderazgo de la televisión pública respecto de la credibilidad y referencialidad no resulta tan evidente. Mientras que la $\mathrm{BBC}$ es la primera opción informativa según declaran los ciudadanos británicos (y a 42 puntos porcentuales se encuentra su segunda opción), en España, entre RTVE (primera opción) y Antena 3 (segunda), solo hay cuatro puntos de diferencia. A la hora de medir la credibilidad surge una situación parecida. La diferencia entre medios públicos y privados a este respecto es muy reducida en España. La credibilidad de la ciudadanía casi se reparte a partes iguales entre televisión pública y privadas.

Teniendo en cuenta que la credibilidad es premisa básica de la confianza y que la reputación implica gozar de dicha confianza, se apunta un problema de urgente gestión: tanto públicos internos como públicos externos no están viendo satisfechas sus expectativas y no confían en sus relaciones con el medio público.

\section{Proactividad en la gestión reputacional: ¿Existe?}

Sintetizaba Villafañe (2004) que la proactividad en la gestión reputacional se mide con diversos indicadores como la existencia de una política formal de reputación corporativa, el establecimiento de objetivos operativos de reputación o la eliminación de riesgos reputacionales.

Teniendo en cuenta que el plan de comunicación suele ser un documento escrito de carácter confidencial al que no se puede acceder desde instancias ajenas, y donde suelen figurar los objetivos a nivel de comunicación que se marca la organización, lo que podría evaluarse a este respecto es la sala de comunicación de RTVE como espacio que visibiliza la imagen de la organización.

A este respecto, partiendo de algunas recomendaciones sobre lo que debería ser una sala de comunicación (Costa-Sánchez, 2017), se detectan una serie de ítems que apuntan a un espacio vertical, unidireccional y poco transparente. 
Así, la sala de comunicación de RTVE se estructura en dos grandes apartados, notas de prensa y descargas (además de la portada). Las notas de prensa pueden localizarse por medio de un buscador de palabras o por fecha. Son comunicados a medio camino entre lo $1.0 \mathrm{y}$ lo 2.0. Son compartibles y reenviables, pero presentan pocos hipervínculos y, paradójicamente, escaso material audiovisual más allá de imágenes que no son descargables. Sí existe galería de vídeos en un menú vertical independiente.

El apartado de descargas presenta un acceso restringido, lo que convierte esta sala de comunicación en una sala de prensa, obviando algunos de los cambios que sugerían para dichos espacios Pino y Obispo (2013). A pesar de que la información interesa a los ciudadanos, los activistas, los influencers, las ONGDs y todo tipo de actores sociales, solo los periodistas tendrán acceso a dichos materiales.

Lo relativo a la identidad gráfica corporativa de los distintos canales se encuentra en otro apartado diferente del de la Sala de comunicación, que suele ser su lugar natural. En concreto bajo la denominación de Imagen corporativa (Sobre Nosotros).

Se detecta una falta de transparencia en la ausencia de la visibilización de los profesionales del departamento de comunicación de la entidad, así como de los canales de comunicación que permitan contactarlos. No aparece en el marco de dicho espacio ninguna forma de contacto con la Dirección de Comunicación de la entidad.

En general, resulta poco presta a la escucha y al diálogo. Obstaculiza información al ciudadano, el acceso a sus profesionales y no ofrece nada a mayores de las notas de prensa correspondientes. Tampoco integra los medios sociales como parte de los contenidos del espacio. Es poco innovadora y restringida. Apunta más a la reactividad que a la proactividad en la gestión reputacional.

\section{Conclusiones}

Son los tres principios de la gestión de la buena reputación. Valores, comportamiento coherente y comprometido y proactividad. La dimensión axiológica está ahí y se encuentra reflejada en una serie de códigos y normas de autorregulación y profesionales. 
El problema resulta cuando no se traduce en un comportamiento corporativo coherente. El hecho de que los trabajadores de la entidad critiquen la manipulación y la falta de independencia va a generar en la ciudadanía la consecuente falta de credibilidad. Porque además se lo están comunicando aquellos profesionales que tienen marca propia, que tienen su propia reputación y más credibilidad que la casa. Es lo contrario al employer advocacy. Y una crisis de credibilidad sostenida en el tiempo. Mientras haya un comportamiento corporativo denunciado por sus trabajadores, se pierde la coherencia entre los valores y el compromiso corporativo. Se rompe el pacto de credibilidad y confianza. De hecho, credibilidad y confianza son dos cuestiones que los ciudadanos acusan a respecto de RTVE, que a pesar de gozar de la trayectoria y bagaje de haber acompañado a la sociedad española durante décadas, no traduce ese valor potencial en confianza y referencialidad.

Por mucho que se haya creado un portal de transparencia, una figura del defensor del espectador o se publiquen las memorias de Responsabilidad Social Corporativa, el esfuerzo es inútil si el comportamiento dice lo contrario. Si los ciudadanos ven en sus pantallas a profesionales que no creen en la marca. Coherencia es el principio que debe guiar lo que se dice y lo que se hace. Habrá que observar cómo continúa evolucionando dicha movilización y cómo sale y se recupera la entidad de la grave merma reputacional que conlleva dicho desgaste.

Por otra parte, la proactividad va más allá de una sala de comunicación encorsetada, limitada, poco innovadora y creativa. Aportar branded content, darles VOz a sus profesionales, ofrecer escucha y contacto, abrirla a la sociedad podrían ser algunas claves para mostrar en el contenido y en la forma, que se apuesta por un nuevo modelo de relación con los ciudadanos más simétrico, más interactivo y de auténtico servicio público. 


\section{Referencias}

AIMC (2018). Estudio general de medios. Resumen General. Disponible en https://www.aimc.es/a1mcc0nt3nt/uploads/2018/04/resume gm118.pdf

Barlovento (2018). Análisis televisivo 2017. Madrid: Barlovento.

Recuperado el 20 de enero de 2018 de https://goo.gl/q7iFhn

Campos-Freire, F. Soengas-Pérez, X. y Rodríguez-Castro, M. (2018). "Indicadores de evaluación de los servicios informativos de la radiotelevisión pública”. El profesional de la información, 27(2), 267-277.

Carreras, E., Alloza, Á., y Carreras, A. (2013). Corporate reputation. Madrid: LID Editorial.

Capriotti, P. (2006). Concepción e importancia actual de la Ciudadanía Corporativa. Razón y palabra, 11(53).

Cerezo, J. y Cerezo, P. (2017). La televisión que viene. Madrid: Evoca Comunicación e Imagen.

Cornelissen, J. (2011). Corporate Communication. A guide to theory \& practice. Londres: SAGE.

Costa-Sánchez, C. y Guarinos, V. (2018). Gestión de marca corporativa online de los canales públicos de televisión en Europa. Propuesta de indicadores para su medición”. Revista Latina de Comunicación Social, 73, pp. 895 a 910. http://www.revistalatinacs.org/073paper/1287/46es.html

Costa-Sánchez, C. (2017). Las salas de comunicación online de las entidades bancarias en España: Entre el branded content informativo y el repositorio de notas de prensa. El profesional de la información, 26(4), 744-755.

Dircom (2013). Manual de la comunicación. Madrid: Dircom.

Gutiérrez, F., Islas, O. y Arribas, A. (2018). Hacia una nueva ecología mediática. Alas. Controversias \& Concurrencias Latinoamericanas, 10 (16), 11-22. 
Fernández Lombao, T., y Campos Freire, F. (2013). La Responsabilidad Social Corporativa en las radio-televisiones públicas de Europa. Cuadernos. info, 33, pp. 145-157.

Izquierdo-Castillo, J. (2014). La evolución del sector televisivo: un oligopolio frente a Internet/The Evolution of the Television Industry: an Oligopoly Facing Internet. Historia y comunicación social, 19, 735-745.

López-López, P.C.; Puentes-Rivera, I. y Rúas-Araújo, J. (2017). Transparencia en televisiones públicas: desarrollo de indicadores y análisis de los casos de España y Chile. Revista Latina de Comunicación Social, 72, pp. 253-272. http://www.revistalatinacs.org/072paper/1164/14es.html DOI: $10.4185 /$ RLCS-2017-1164

Manfredi Sánchez, J. L. (2011). Escenarios y retos de la televisión pública en España. adComunica. Revista de Estrategias, Tendencias e Innovación en Comunicación, $\mathrm{n}^{\circ} 1$, pp. 49-62.

Martínez, I., y Olmedo, I. (2010). Revisión teórica de la reputación en el entorno empresarial. Cuadernos de Economía y Dirección de la Empresa, 13(44), 59-77.

Pew Research Center (2018). Across Western Europe, public news media are widely used and trusted sources of news. Disponible en http://www.pewresearch.org/fact-tank/2018/06/08/westerneurope-public-news-media-widely-used-and-trusted/

Pino, I. y Obispo, M. (2013). Adiós sala de prensa, bienvenida web 2.0. De la prensa de masas a la comunicación en redes. Disponible en http://www.desarrollandoideas.com/publico/130405_dmasi_ Articulo_web20.pdf

Túñez, M. (2012). La gestión de la comunicación en las organizaciones. Sevilla: Comunicación Social.

Van Riel, C. B. (1997). Comunicación Corporativa. Madrid: Prentice Hall.

Villafañe, J. (2017). Gestión de la reputación y los intangibles empresariales. Madrid: Villafañe y Asociados. Disponible en http://www.villafane.com/wp- 
content/uploads/2017/11/Informe-intregrado-demetodologias-VA.pdf?x26871

Villafañe, J. (2004). La buena reputación. Claves del valor intangible de las empresas. Madrid: Pirámide.

Xifra, J. (2014). Manual de Relaciones públicas e institucionales. Madrid: Tecnos. 


\title{
Las narrativas inmersivas como valor de innovación en las radiotelevisiones públicas europeas
}

\author{
Sara Pérez-Seijo \\ Universidade de Santiago de Compostela \\ María José Benítez de Gracia \\ Universidad Carlos III de Madrid
}

PARA CITAR: Pérez-Seijo, S. y Benítez de Gracia, M.J. (2018). Las narrativas inmersivas como valor de innovación en las radiotelevisiones públicas europeas. En Pérez-Seijo, S., Rodríguez-Castro, M. y Túñez-López, M. (Eds.), Debates sobre valores e indicadores del servicio audiovisual público en Europa (pp. 111-126). Cuadernos Artesanos de Comunicación, cac142. La Laguna (Tenerife): Latina. DOI: $10.4185 / \operatorname{cac} 142$

\section{Resumen}

El servicio audiovisual público tiene la misión de servir a la ciudadanía y, por lo tanto, de consolidarse como indispensable y convertirse en referente. Por ello, debe estar al día también en innovación para seguir el compás de los medios privados y para garantizar que la sociedad pueda acceder a los últimos avances en materia de producción, difusión y consumo de contenidos. En este sentido, desde finales de 2015 se ha venido observando un creciente interés, por parte de la esfera mediática internacional, en implementar las narrativas inmersivas. La Unión Europea de Radiodifusión, en respuesta a esta tendencia, ha incentivado la experimentación y aplicación de estos recursos entre sus 
miembros con el fin de seguir el ritmo de la carrera de innovación que tanto caracteriza a la segunda década del tercer milenio. Radiotelevisiones públicas como France Télévisions, Radiotelevisión Española o Radio Télévision Belge de la Communauté Française ejemplifican esta apuesta.

Palabras clave: innovación, narrativas inmersivas, vídeo $360^{\circ}$, Unión Europea de Radiodifusión, servicio audiovisual público.

\section{Introducción}

Sacudidas por el contexto de la última crisis económica internacional y la continua expansión tecnológica que han marcado el periodismo de la última década, las radiotelevisiones públicas europeas, en su labor de servicio público, han tratado de garantizar su supervivencia aplicando fórmulas que les permitan explorar nuevos formatos para frenar su estancamiento y anticiparse a las nuevas audiencias.

Al amparo de esta misión, la Unión de Radiodifusión Europea (UER o EBU, siglas en inglés) ha apostado por la promoción de valores como la innovación, así como por el desarrollo de las nuevas tecnologías y formatos emergentes, entre los que destacan los contenidos basados en realidad virtual (RV) y/o grabación en vídeo $360^{\circ}$. De este modo, las narrativas inmersivas, que habían comenzado a aflorar a finales de 2015 en los medios periodísticos, han cobrado gran importancia dentro de la UER. La ejecución de esta meta se ha materializado en proyectos e iniciativas promovidas desde las áreas de innovación de las radiotelevisiones públicas de los diferentes países.

\subsection{La Unión Europea de Radiodifusión: narrativas y técnicas inmersivas como estrategia de innovación}

La Unión Europea de Radiodifusión es la principal alianza internacional de medios de servicio público. Opera bajo la misión de convertir a estos entes en indispensables para la sociedad y, por ello, en sus Estatutos (2015) recoge una serie de objetivos encaminados a alcanzar tal fin. No obstante, en el presente capítulo solo serán abordados dos. Concretamente, aquellos que se vinculan con el objeto de estudio: la promoción y desarrollo de valores como el de la innovación; y el empleo y también desarrollo de las últimas tecnologías 
de información y comunicación para garantizar a la sociedad el acceso a las mismas.

La UER dispone del departamento Technology \& Innovation para asegurar el cumplimiento de ambas metas. Su cometido es experimentar, desarrollar e implementar nuevos formatos, tecnologías y técnicas de radiodifusión; todo ello en un afán por convertirse en "una fuerza impulsora de innovación y creatividad" (European Broadcasting Union, 2012: 5). En este sentido y de cara al 2018, la UER decidió centrar sus esfuerzos en la radio digital, la televisión de alta definición (HDTV), la inteligencia artificial y, entre otros elementos, la producción de contenidos con $\mathrm{RV}$ y/o grabación $360^{\circ}$-narrativas inmersivas o VR storytelling-.

Precisamente la aplicación de estos dos últimos recursos en el sector mediático mundial ha ido in crescendo desde finales de 2015 (Doyle, Gelman y Gill, 2016). Tal ha sido la influencia que ha alcanzado, que la propia UER ha tratado de promover entre sus diferentes miembros la experimentación con las tecnologías de realidad virtual y las imágenes $360^{\circ}$, especialmente en vídeo. Un objetivo que ha intentado lograr proporcionando plataformas e incluso organizando eventos o encuentros pensados para que las radiotelevisiones públicas europeas, entendidas estas como aquellas que forman parte de la alianza, puedan no solo intercambiar experiencias, sino también compartir conocimiento sobre este nuevo tipo de producción (European Broadcasting Union, 2017).

En el informe Virtual reality: How are public broadcasters using it?, publicado en julio de 2017, la UER estimaba la narración con RV como un formato que, al margen de presentarse como innovador, ofrecía también nuevas oportunidades y ventajas para la creación de contenido, la narración y la participación de la audiencia. Al fin y al cabo, las narrativas inmersivas han entrado en el panorama comunicativo internacional, no solo en el radiodifusor público europeo, como una nueva forma de producción de contenidos que permite a los receptores experimentar en primera persona los acontecimientos o sucesos de un relato (De la Peña et al., 2010).

Su aplicación se materializa en experiencias "en las que los usuarios pueden participar, actuar y reaccionar, en lugar de simplemente 
observar o escuchar de manera pasiva" (European Broadcasting Union 2017: 10). Sin embargo, el formato más empleado por los miembros de la UER es el vídeo $360^{\circ}$, una tendencia compartida con el resto de medios a nivel mundial (Hardee y McMahan, 2017).

\section{La innovación como valor y proceso de cambio para la supervivencia del periodismo}

La última década, marcada por la contracción económica a nivel mundial, ha sido especialmente adversa con la prensa escrita y el sector audiovisual. Esto se ha traducido en reducciones de audiencias y de ingresos (Salaverría, 2012: 161; Díaz-Nosty, 2011) que ha tenido como respuesta un alto número de despidos y cierre de medios especialmente virulento entre 2010 y 2013 (Asociación de la Prensa de Madrid, 2013: 83). A este respecto, los medios de servicio público han sido uno de los principales colectivos afectados. Aunque los datos de los últimos años comienzan a suavizar este panorama (Asociación de la Prensa de Madrid, 2016), quedan pendientes cuestiones estructurales que afectan a la capacidad operativa de los medios y a la dinámica de trabajo de los periodistas (García-Avilés et al., 2018: 371).

Paralelamente a esta crisis de dimensión económica, existe otra de carácter estructural derivada del cambio de paradigma tecnológico en la industria de la comunicación (Salaverría, 2015a: 397). La llamada convergencia tecnológica como proceso multidimensional, y facilitada por la implantación generalizada de las tecnologías digitales, ha propiciado un cambio en las rutinas de trabajo y en la creación y el consumo de los contenidos hacia formatos multiplataforma (Salaverría y García-Avilés, 2008: 44; Díaz-Noci, 2010: 562). La velocidad en la que se suceden los avances tecnológicos obliga a los medios a una constante renovación para estar en contacto con una audiencia cada vez más viral y fragmentada (Rodríguez y Torrado, 2017: 148). Las últimas cifras muestran una clara inclinación de los lectores hacia el consumo de información mediante dispositivos móviles (Salaverría, 2015b: 149), en un escenario donde el smartphone se ha convertido en el principal equipo para acceder a la red (Rodríguez y Castillo, 2017: 47). Esto implica la necesidad de plantear soluciones para un futuro cercano donde la respuesta de los medios deberá estar dirigida hacia un periodismo “con, desde y mediante móviles” (Salaverría, 2016: 259). 
En este panorama marcado por el constante cambio tecnológico, la segmentación de las audiencias y el propio modelo de negocio, la innovación en comunicación se ha convertido en un valor clave para garantizar la supervivencia de los medios (García-Avilés et al., 2016: 370). Por ello, y ante la ardua tarea que supone para los medios de servicio público, dadas sus propias limitaciones económicas, la UER trata de frenar la obsolescencia que acecha a sus miembros actuando como una palanca impulsora de innovación.

Innovar en comunicación supone, siguiendo a Cabrera, un

"Proceso de creación o modificación del producto o servicio que ofrecen los medios de comunicación mediante la integración de nuevas tecnologías, rutinas y modelos de negocio en su estructura, organización, proceso de producción y difusión de la información a fin de ampliar y diversificar su mercado con alguna ventaja competitiva o creación de valor" (Cabrera, 2016: 26).

Para que una iniciativa periodística sea innovadora ha de ser nueva, diferente a lo existente, experimentar con las posibilidades creativas y los recursos, anticiparse a la competencia y, finalmente, conseguir un resultado exitoso (García-Avilés et al., 2018: 373). Más la innovación puede manifestarse en la organización, en el tipo de producto, en la distribución o en la comercialización (García-Avilés et al., 2018: 376).

\subsection{El papel de los laboratorios de innovación periodística}

Desde la dimensión organizativa en torno a la innovación periodística, destaca la puesta en marcha en los medios de equipos multidisciplinares para el desarrollo de nuevos proyectos, incentivando la innovación dentro de la propia compañía (Sádaba y Salvaverría, 2016a: 152). Entre ellos, los laboratorios de innovación periodística, medialabs o labs, definidos como "una unidad interna de la empresa periodística, dotada de cierto grado de autonomía operativa y equipo humano propio, cuyo cometido es idear y promover innovaciones de carácter tecnológico, editorial y/o comercial, para la mejora competitiva de la organización" (2016a: 153).

Estas unidades cobran un papel destacado para el impulso y desarrollo de los medios y permiten experimentar con contenidos, tecnologías y otros aspectos (García-Avilés, 2018: 360). Para ello, se encargan de rastrear las últimas tendencias en producción y ayudan a poner en 
marcha nuevos proyectos aprovechando las posibilidades de la tecnología digital (Del Campo y Zaragoza, 2017: 154). Siguiendo a Salaverría, el origen de estos departamentos con vocación innovadora se remonta a la década de los 90, inspirados por el modelo del MIT Media Lab, inaugurado en 1985 en la School of Architecture and Planning del Massachuse s Institute of Technology. Ya en el s.XXI, aunque durante la primera década se ponen en marcha algunos proyectos relevantes, como el impulsado en 2007 por la radiotelevisión pública estadounidense, PBS Idea Lab, si bien, no será hasta 2010 cuando comience a consolidarse el interés por el potencial de esta idea (Salaverría, 2015a: 401).

Para Salaverría existen cuatro modelos de laboratorios de innovación en medios: los centrados en el desarrollo de tecnologías y aplicaciones digitales, los orientados a la innovación en lenguajes y a la ideación de formatos multimedia, los que tratan de promover proyectos empresariales e iniciativas comerciales, y los dedicados a la formación mediática de periodistas.

Las radiodifusoras públicas europeas, en un afán por seguir el ritmo de la carrera de innovación mediática, han ido creando a lo largo de la segunda década del s. XXI sus propios laboratorios o, en su defecto, departamentos de experimentación con nuevos formatos y lenguajes. Algunos ejemplos son: Nouvelles Écritures de France Télévisions (Francia); Lab RTVE de Radiotelevisión Española (España); WebCréation de Radio Télévision Belge de la Communauté Française (Bélgica); o Taster y BBC News Lab de la British Broadcasting Corporation (Reino Unido).

Cabe destacar la labor que la UER (2017) trata de promover y desarrollar con los laboratorios o departamentos de innovación de sus miembros en materia de narrativas de RV, lo mismo en el caso de otros formatos o recursos. En este sentido, a través del anteriormente mencionado departamento Technology \& Innovation, organiza workshops y eventos de RV, así como también proporciona plataformas de discusión e intercambio sobre dicha narrativa con el fin de compartir conocimiento, ideas y experiencias entre sus miembros. Si cabe, una de las decisiones más relevantes tomadas por la UER a este respecto ha sido la cofundación, en 2017, del VR Industry Forum o VRIF. 


\subsubsection{Innovación desde el interior de Radiotelevisión Española: el Lab RTVE}

En España, el primer laboratorio de periodismo surgido dentro un medio de titularidad pública es el Laboratorio de Innovación Audiovisual de RTVE o Lab RTVE. Radiotelevisión Española lo creó en junio de 2011 con el objetivo de desarrollar y experimentar nuevas narrativas audiovisuales a través de formatos como webdocs, $\mathrm{RV}$ y vídeo 360 (García-Avilés, 2018: 360). De hecho, destaca entre los seis primeros medios españoles con iniciativas periodísticas más innovadoras (De Lara González et al., 2015: 240).

Definido a sí mismo como "un departamento de innovación audiovisual que investiga nuevas narrativas y lenguajes para detectar la mejor forma de contar cada historia" (Salaverría, 2015a: 403; Sádaba y Salaverría, 2016b: 45), en un principio este laboratorio estaba constituido por dos personas, Miriam Hernanz e Ismael Regio, si bien a lo largo del tiempo se han ido uniendo otras provenientes de distintas áreas (redacción, diseño web y desarrollo).

La expansión y el desarrollo de las tecnologías inmersivas les ha llevado también a explorar este formato a partir de 2015 siendo uno de sus primeros trabajos Ingeniería Romana, un proyecto multimedia e interactivo sobre la ciudad romana Tarraco, donde se combinan técnicas de grabación $360^{\circ}$ con recursos de RV y aumentada. Entre los contenidos que incluye se encuentran cuatro vídeos $360^{\circ}$ que trasladan al receptor a diferentes localizaciones de la ciudad colonial: Circo, Foro de la colonia, Recinto de culto y Anfiteatro.

El Lab RTVE no ha dejado de experimentar y producir contenidos con narrativas inmersivas desde entonces, tanto trabajos de ficción como de no ficción, así como de temáticas de diversa índole (teatro, cultura, deportes, etcétera). Así pues, tras Ingeniería Romana han venido proyectos como El Ministerio del Tiempo: El tiempo en tus manos (2016), un episodio de RV de la serie El Ministerio del Tiempo, emitida en televisión por la propia RTVE; Encierros 360 (2016), los encierros de San Fermín 2016 en vídeo esférico; y Vive Rio: Heroinas (2016), sobre las deportistas españolas que participaban en los Juegos Olímpicos de Río en 2016.

Estrenada también en 2016, y todavía en activo en 2018, Escena $360^{\circ}$ es una iniciativa cuya finalidad era y es ofrecer piezas inmersivas de teatro, 
ballet o música clásica, de ahí que algunas de estas creaciones sean fruto de la colaboración del Lab RTVE con el Centro Dramático Nacional caso de La Cocina (2016)- o, entre otros órganos, con el Ballet Nacional de España -para Alento (2017)-.

Miriam Hernanz (M. Hernanz, Comunicación personal, 2018), responsable del Lab RTVE -a fecha de mayo de 2018-, explica que el proceso de creación de este tipo de innovaciones con narrativas inmersivas se lleva a cabo a través de una doble vía. Por un lado, se basa en el aprovechamiento de recursos ya existentes. Así ocurre en el caso de Ingeniería Romana, donde se utiliza un vídeo $360^{\circ}$ grabado previamente para un documental y al que no se le daba uso. Mas en otras ocasiones, se ha contado con la colaboración de productoras externas. Esta situación se ha dado en proyectos como Ministerio VR: Salva el Tiempo -una experiencia inmersiva derivada de la serie El Ministerio del Tiempo, a priori mencionada-, fruto de una producción conjunta entre el Lab RTVE, Future Lighthouse y Onza Entertainment; o el ya comentado Vive Río: Heroínas, que contó con la participación de la productora InMediaStudio. En ambos casos, esta externalización no se concibe como un gasto, sino como una inversión hacia la empresa ya que, en palabras de Hernanz, "lo que se pretende con ello es el que conocimiento se quede en casa, quedarse con el knowhow" (2018).

La gran mayoría de los contenidos inmersivos producidos por el Lab RTVE pueden ser visionados y disfrutados desde la propia página del laboratorio (http://lab.rtve.es), concretamente desde la sección $V R$. En este apartado se recogen aquellas iniciativas y productos en los que han sido empleados recursos inmersivos, una estrategia que agiliza la identificación por parte de los usuarios.

Cada publicación recogida en la sección hace referencia a una pieza o a un contenido determinado. Algunas de estas permiten consumir los trabajos desde la propia página del Lab RTVE, más otras actúan únicamente como canales informativos y promocionales. Cuando esto sucede, normalmente se debe a que dichos contenidos han sido planteados como apps móviles, generalmente disponibles tanto en la App Store y Google Play como en Oculus. Entre ellas se encuentran Ministerio $V R$, del proyecto antes referido, o Cervantes $V R$, que relata la 
vida del escritor Miguel de Cervantes y su obra por excelencia Don Quijote de la Mancha, un contenido ofrecido en clave teatral.

\subsubsection{WebCréation: célula de innovación de la Radio Télévision Belge de la Communauté Française}

En septiembre de 2014, la Radio Télévision Belge de la Communauté Française, más conocida por sus siglas RTBF, estrenaba WebCréation, una célula de creación de contenidos web impulsada desde el departamento RTBF Interactive. La iniciativa nacía para dar respuesta a un público cada vez más conectado y activo que demandaba $-y$ demanda- una mayor producción de contenidos pensados para las plataformas digitales, como las redes sociales, y planteados para un consumo online.

Años después de su lanzamiento, WebCréation se ha asentado como una palanca impulsora de creaciones audiovisuales con nuevas narrativas. Su interés principal radica en el público joven y ello lo evidencia su apuesta por formatos como los webdocs, las series sonoras y las webseries, junto con la aplicación de estrategias y recursos narrativos como el transmedia y el $V \mathrm{R}$ storytelling.

Esta célula cuenta con su propio sitio web dentro de la página oficial de la RTBF (https://www.rtbf.be/webcreation), una plataforma pensada para facilitar el acceso y el consumo de los proyectos que se realizan. A nivel de diseño, presenta similitudes con respecto a la página del Lab RTVE ya que también cuenta con una estructura basada en secciones que recogen contenidos en determinados formatos o en los que se han aplicado ciertos recursos narrativos. Al igual que sucedía en el caso español, WebCréation dedica uno de los apartados a contenidos inmersivos. Este, en concreto, recibe por título $V \mathrm{R}$ et 360 , un nombre identificativo y representativo, pues hace alusión a los dos recursos centrales de las narrativas inmersivas: la realidad virtual y la grabación en $360^{\circ}$.

La vie à venir en 360: dans la peau d'un prématuré fue la primera experiencia inmersiva en estar disponible dentro de esta sección y en consecuencia también en WebCréation. Esta pieza, cuya fecha de publicación se remonta a noviembre de 2016, consiste en una ficción documental en vídeo $360^{\circ}$ que relata los primeros días de vida de Eva, una niña que nace de manera prematura. Por medio de esta historia, de una clara 
temática social, se expone y visibiliza la realidad de los partos prematuros y los cuidados requeridos.

En marzo de 2017 se publicó un segundo trabajo: White Pig (Harcelée), una ficción teatral sobre el ciberacoso entre adolescentes. Esta experiencia ha sido producida conjuntamente entre la RTBF y el Teatro de Lieja, de ahí que la escenografía recuerde a la de las obras de teatro. Lo que destaca de este producto es que la historia ha sido dividida en capítulos, un total de cinco vídeos $360^{\circ}$ a través de los que se cuenta la historia de Camille, una quinceañera que sufre humillaciones y amenazas en el colegio.

Por medio de esta historia, aunque de ficción, la RTBF intenta denunciar y exponer el problema social que representa el acoso en el entorno escolar con el fin de crear conciencia y suscitar la reflexión entre los espectadores. Este tipo de contenidos, así como sus mensajes, se enmarcan dentro de los valores que la radiodifusora belga defiende, y debe defender, por su propia condición de medio de servicio público $y$, por tanto, por y para la sociedad.

\subsubsection{France tv lab: una plataforma online de France Télévisions}

France Télévisions, la radiodifusora pública de Francia, activó en setiembre de 2017 France tv lab (www.francetelevisions.fr/lab), una plataforma en línea pensada para recopilar los proyectos de innovación realizados desde sus diferentes departamentos, como el laboratorio Nouvelles Écritures o el MediaLab. Cada uno de ellos desarrolla sus propios proyectos en base a un cometido determinado: experimentar con nuevas tecnologías y formatos narrativos, emplear o aplicar formas de gestión novedosas o, incluso, desarrollar y probar nuevos formatos publicitarios.

Por tanto, France tv lab se presenta como un escaparate informativo en el que France Télévisions aúna sus diferentes iniciativas de innovación para mantener a su audiencia al tanto de sus trabajos. Mas no solo actúa como una vía de anuncio y difusión de proyectos realizados o en activo, sino que, en ocasiones, también permite que los usuarios prueben algunos de los contenidos en cuestión.

La estructura web de esta plataforma es distinta a la de las anteriores, pues en lugar de separar los proyectos por secciones, engloba todas las informaciones publicadas en un apartado común titulado "Projets". 
¿La razón? La filosofía del France tv lab difiere en gran medida de la del Lab RTVE y de la de WebCréation porque su misión no es ser un laboratorio o célula de innovación, sino servir de contenedor de las diferentes innovaciones llevadas a cabo desde el interior de France Télévisions y, al fin y al cabo, darlas a conocer. En este sentido, las publicaciones que France tv lab recoge son artículos sobre los trabajos que la radiodifusora francesa ha producido, que se encuentran en activo o que prepara para un futuro próximo. Con todo, algunas de estas informaciones incluyen vías de acceso a los propios contenidos que presentan, ya sean directas -consumo desde la propia publicación- o bien mediante la inclusión de links que redirigen a app stores, otras páginas del ente u otras plataformas ajenas -YouTube, Facebook, etc.-

Uno de los formatos con los que France Télévisions experimenta es el inmersivo, tanto en su vertiente de RV -imágenes creadas de manera sintética- como de video $360^{\circ}$. El Torneo de Roland-Garros fue uno de los primeros acontecimientos en los que centró su interés para adentrarse en la creación inmersiva. La aventura comenzó en 2015 en colaboración con Intel y continuó en 2016 con una mejora de la calidad de los contenidos. Pero su aproximación a estas narrativas en el campo de los deportes no quedó ahí. Para la edición de 2017 France Télévisions sorprendió con su cobertura inmersiva del evento de tenis. Por un lado, optó por producir un total de seis reportajes breves en vídeo $360^{\circ}$, una colección de piezas que fueron publicadas diariamente durante seis días. Por otro, el lanzamiento de Roland-Garros VR, una app para Oculus y cuyos contenidos también están disponibles en la app France tv sport 360, disponible en App Store y Google Play.

Aunque France tv lab actúa como un portal informativo de proyectos de innovación, algunas de las informaciones incluyen, como se ha comentado a priori, contenido apto para su disfrute. Es el caso de la publicación Roland-Garros en $360^{\circ}$, con fecha de mayo de 2017. Aunque en esta no se incluyen todos los contenidos inmersivos disponibles, sí se insertan desde YouTube cuatro de los seis reportajes grabados en vídeo esférico. Junto a esto, se incluyen también enlaces a las ya mencionadas apps stores para la descarga directa de la aplicación de la sección deportiva de France Télévisions, Francetv Sport.

Asimismo, France Télévisions ha aprovechado las oportunidades de las narrativas inmersivas para ofrecer coberturas de acontecimientos 
culturales y/o tradicionales. En concreto, de los preparativos de la fiesta nacional del 14 de julio, día en el que se conmemora la toma de la Bastilla. Precisamente por ello, en France tv lab se dedica una información a estos contenidos. La publicación, que lleva por título Le 14 Juillet en $360^{\circ}$ y fue publicada en julio de 2017, incluye dos vídeos esféricos insertados desde Facebook: uno muestra cómo los bomberos se preparan para ofrecer servicio y, en caso de ser necesario, auxilio en dicha festividad; mientras que el otro se centra en los ensayos de la Guardia Republicana.

La radiotelevisión francesa también ha apostado por la creación de experiencias que aproximen los platós informativos a los espectadores. Esto se materializa en una pieza de en torno a dos minutos que traslada al receptor a los momentos previos del informativo de las 20 horas que emite el canal France 2 y que, en el momento de su filmación, presentaba la periodista Anne-Sophie Lapix. El proyecto, grabado el 21 de marzo de 2018, es fruto de una colaboración entre Orange Labs y los equipos de France Télévisions de Direction de l'Information, Innovations \& Développements y el MediaLab. Con todo, su presentación oficial se retrasó a septiembre de 2018, con el fin de presentarlo en las Jornadas Europeas de Patrimonio celebradas en ese mismo mes.

\section{A modo de síntesis: hacia dónde se dirige la producción inmersiva}

La apuesta de las radiodifusoras públicas por las narrativas inmersivas va más allá de la mera experimentación tecnológica. Casos como el de France Télévisions, Radiotelevisión Española o Radio Télévision Belge de la Communauté Française prueban que el servicio audiovisual público trata de aprovechar las oportunidades y ventajas del formato inmersivo, con foco en el vídeo $360^{\circ}$, y producir contenidos no solo de valor informativo, sino también social, educativo y formativo.

Aunque cada radiotelevisión muestra un ritmo de creación de piezas con narrativas inmersivas distinto, pueden igualmente observarse y, en consecuencia, extraerse una serie de tendencias comunes en cuanto al uso que han hecho de estas hasta 2018. Por un lado, se advierte una propensión a desarrollar apps temáticas o, en su defecto, dedicadas a un contenido muy específico. Junto a esto, se aprecia también un claro 
intento por reformular y aportar valor añadido a las coberturas de eventos deportivos con grandes audiencias.

Además, el $V R$ storytelling se presenta como una alternativa más para expandir universos narrativos, esto es, para iniciativas transmedia. $\mathrm{Y}$, por último, se percibe que valores como el social -estrechamente vinculado a la concienciación y a la reflexión de la sociedad-, el educativo y el formativo -destacando aquí la relevancia del teatroganan peso en este tipo de producciones.

\section{Referencias bibliográficas}

Asociación de la Prensa de Madrid (2016). Informe Anual de la Profesión Periodística 2016. Recuperado en https://goo.gl/4q7yMM

Asociación de la Prensa de Madrid (2013). Informe Anual de la

Profesión Periodística 2013. Recuperado en https://goo.gl/3HtMrk

Cabrera, M.A. (2016). La innovación: concepto y taxomización. En Sádaba, C-, García Avilés, J.A. y Martínez-Costa, M.P. (coords.), Innovación y desarrollo de los cibermedios en España (23-30). Pamplona: EUNSA.

García-Avilés, J.A. (2018). Resultados de la innovación en los laboratorios de medios: el caso de El confidencial.LAB. El profesional de la información, 27(2), 359-366.

García-Avilés, J.A., Carvajal Prieto, M. y Arias Robles, F. (2018). Implantación de la innovación en los cibermedios españoles: análisis de las percepciones de los periodistas. Revista Latina de Comunicación Social, 73, 369-384.

De la Peña, N., Weil, P., Llobera, J., Spanlang, B., Friedman, D., Sánchez Vives, M. y Slater, M. (2010). Immersive Journalism: immersive virtual reality for the first-person experience of news. Presence: Teleoperators and virtual enviroments, 19(4), 291-301.

De-Lara-González, A., Arias-Robles, F., Carvajal-Prieto y M., GarcíaAvilés, J.A. (2015). Ranking de innovación periodística 2014 en 
España. Selección y análisis de 25 iniciativas. Elprofesional de la información, 24(3), 235-245.

Del Campo Cañizares, E. y Zaragoza Fuster, T. (2017). Medialabs españoles. Un análisis de sus formatos narrativos. En Canavilhas, J. y Rodrigues, C. (orgs.), Jornalismo móvel, Linguagem, géneros e modelos de negócio (153-174). Beira: Editora LabCom.IFP. Recuperado en https://goo.gl/qtjfoq

Díaz-Noci, J. (2010). Medios de comunicación en internet: algunas tendencias. El profesional de la información, 19 (6), 561-567. DOI: 10.3145/epi.2010.nov.01

Díaz-Nosty, B. (2011). Libro negro del periodismo en España. Madrid: Asociación de la Prensa de Madrid.

Doyle, P., Gelman, M. y Gill, S. (2016). Viewing the future? Virtual reality in journalism. Recuperado en https://goo.gl/ZJX4UG

European Broadcasting Union (2012). Empowering society: a declaration on the core values of public service media. Recuperado en https://goo.gl/IIRw8D

European Broadcasting Union (2015). Statutes of the European Broadcasting Union. Recuperado en https://goo.gl/L13Rgj

European Broadcasting Union (2017). Virtual reality: How are public broadcasters using it? Recuperado en https://goo.gl/ewgtyX

Hardee, G.M. y McMahan, R.P. (2017). FIJI: a framework for the immersion-journalism intersection. Frontiers in ICT, 4:21, 1-18.

Hernanz, M. (2018, mayo). Entrevista a Miriam Hernanz realizada por María José Benítez. Madrid.

Martínez Rodríguez, L. y Torrado Morales, S. (2017). Reflexiones en torno al periodismo y la narrativa transmedia. En TorradoMorales, S., Ródenas-Cantero, G. y Ferreras-Rodríguez, JG. (eds.), Territorios transmedia y narrativas audiovisuales (165-187). Barcelona: Editorial UOC.

Rodríguez Canfranc, P. y Castillo Holgado, A. (2017). Sociedad Digital en España 2017. Ed. Fundación Telefónica y Ariel. Disponible en https://goo.gl/r2jSn2 
Sádaba, C. y Salaverría, R. (2016a). Los 'labs' de medios en España: modelos y tendencias. En Casero-Ripollés, A. (ed). Periodismo y democracia en el entorno digital (149-164). Salamanca: SEP.

Sádaba, C., y Salaverría, R. (2016b). La innovación y los cibermedios: los labs. En Sádaba, C., García Avilés, JA. y Martínez-Costa, MP. (coords.), Innovación y desarrollo de los cibermedios en España (41-47). Pamplona: EUNSA.

Salaverría, R. (2012). Extrema turbulencia en los medios en 2011. Anuario ThinkEPI, 6, 161-165.

Salaverría, R. (2015a). Los Labs, como fórmula de innovación en los medios. El profesional de la información, 24(4), 397-404.

Salaverría, R. (2015b). Innovar en prensa: dónde, cómo y por qué. En AEDE: Libro Blanco de la Prensa Diaria, 149-154.

Salaverría, R. (2016). Los medios de comunicación que vienen. En Sádaba, C., García Avilés, J.A. y Martínez-Costa, M.P. (coords.), Innovación y desarrollo de los cibermedios en España (255-263).

Pamplona: EUNSA.

\section{Reconocimientos de la investigación}

El texto de esta comunicación está elaborado en el marco de dos proyectos. Por un lado, "Usos y preferencias informativas en el nuevo mapa de medios en España: modelos de periodismo para dispositivos móviles" (Referencia: CSO2015-64662-C4-4-R), del Ministerio de Economía y Competitividad de España, cofinanciado por el Fondo Europeo de Desarrollo Regional (FEDER) de la Unión Europea. Y por otro, el de "Indicadores de gobernanza, financiación, rendición de cuentas, innovación, calidad y servicio público de las RTV europeas aplicables a España en el contexto digital" (Referencia: CSO2015-66543-P) del Programa estatal de Fomento de la Investigación Científica y Técnica de Excelencia, subprograma estatal de Generación de Conocimiento del Ministerio de Economía y Competitividad de España, cofinanciado por el Fondo Europeo de Desarrollo Regional (FEDER) de la Unión Europea. Este trabajo también está elaborado en el marco del programa de actividades de la Red XESCOM (REDES 2016 GI-1641 XESCOM), de la Consellería de Cultura, Educación e 
Ordenación Universitaria de la Xunta de Galicia (Referencia ED341D R2016/019).

Además, Sara Pérez Seijo es beneficiaria del programa de Formación del Profesorado Universitario (FPU16/06156) financiado por el Ministerio de Educación, Cultura y Deporte (Gobierno de España). 


\title{
Legislar la participación en la televisión pública. Recomendaciones a partir de los modelos europeos
}

\author{
Ana María López-Cepeda \\ Universidad de Castilla-La Mancha
}

PARA CITAR: López-Cepeda, A.M. (2018). Legislar la participación en la televisión pública. Recomendaciones a partir de los modelos europeos. En PérezSeijo, S., Rodríguez-Castro, M. y Túñez-López, M. (Eds.), Debates sobre valores e indicadores del servicio audiovisual público en Europa (pp. 127-142). Cuadernos Artesanos de Comunicación, cac142. La Laguna (Tenerife): Latina. DOI: $10.4185 / \operatorname{cac} 142$

\section{Resumen}

La participación en los medios de comunicación públicos se ha convertido en un elemento clave como presupuesto necesario ante las nuevas exigencias sociales. La idea que subyace del concepto amplio de participación es que se llegue a las comunidades a través de un procedimiento que permite la negociación entre una diversidad de opiniones (Carpentier, 2011: 20). Se plantea este artículo para conocer la regulación legal sobre participación en las televisiones públicas de la $\mathrm{UE}$, en las que este concepto adquiere una especial importancia por su valor añadido ante la sociedad. Se analizarán, para ello, los principales mecanismos previstos legalmente relacionados con la participación institucionalizada y con la participación a través de los medios de comunicación (Azurmendi y Muñoz-Saldaña, 2016) (Carpentier, 2011). 
Palabras clave: televisión pública, participación institucionalizada, representación mediada, derecho de acceso.

\section{Introducción}

La rendición de cuentas y participación son conceptos fundamentales que están asumiendo los medios de comunicación como presupuesto imprescindible para su adaptación a las nuevas exigencias sociales. Los reguladores europeos, sin embargo, han sido demasiado lentos para darse cuenta del valor de estos conceptos, incluyendo los intereses de las audiencias y de los ciudadanos, no solo como consumidores (Hasebrink, 2011: 321). Se encuentran algunas referencias en la Recomendación CM/Rec (2012)1, referida a la necesidad de una apertura basada en la participación y el compromiso (art. 42) (LópezCepeda, 2017: 49), pero es una regulación de mínimos y propia de políticas blandas sin vinculación real.

"Podemos concluir que la participación activa de las audiencias o el público en los medios audiovisuales no está regulada más allá de las directivas que afectan a la protección de los derechos de los consumidores y el derecho a rectificación de la directiva de Servicios Audiovisuales. Tampoco en las resoluciones sobre el servicio público de radiodifusión del Parlamento Europeo se encuentran referencias a la participación de la audiencia como función esencial o importante de su misión.” (Azurmendi, Llorens, López-Vidales y Bas-Portero, 2015: 499).

Se plantea este estudio para conocer la regulación legal sobre participación en las televisiones públicas europeas, en las que este concepto adquiere una especial importancia por su valor añadido ante la sociedad. Solo se analizarán los mecanismos previstos en la legislación de medios públicos de los distintos Estados miembros y no se tendrán en cuenta otras políticas sobre participación a través de mecanismos de autorregulación o corregulación.

A partir del análisis se expondrán unas recomendaciones de mejora. No se pretende hacer un manual de participación, dado que cada realidad es diferente, pero sí conocer unos indicadores mínimos para mejorar las políticas legislativas sobre participación en los medios 
audiovisuales. Tampoco se pretende realizar una relación detallada de todas y cada una de las leyes que regulan la televisión pública, sino solo de los mecanismos que puedan parecer más relevantes de cara a la elaboración de dichas sugerencias.

\section{Rendición de cuentas y participación}

El concepto de rendición de cuentas o accountability ha ido instaurándose en las sociedades democráticas a través de su concepto político (O' Donnell, 2004), entendiéndose como tal la "supervisión permanente y constante de la gestión pública” (López-López, PuentesRivera y Rúas-Araújo, 2017: 257) y tornándose en principio fundamental de los ordenamientos jurídicos (Filgueiras, 2011) (LópezCepeda y Manfredi-Sánchez, 2018: 414).

Los medios de comunicación y, en esencia los de servicio público, como amplios generadores de opinión pública que son deben asumir la rendición de cuentas como mecanismo imprescindible y fundamental. La crisis de credibilidad que asola a estos en algunos Estados miembros como el español evidencia la necesidad de recuperar la confianza con los usuarios conociendo sus intereses y preocupaciones y haciéndoles partícipes del mismo sistema.

La participación se entiende como elemento clave en la rendición de cuentas. Este término se usa habitualmente, en el contexto de los medios de comunicación, como "contenidos generados por los usuarios, y también en las prácticas que permiten que la audiencia se involucre en la producción de programas (Hargittai y Walejko, 2008)" (García-Avilés, 2011: 176). Si bien esta debe entenderse de forma más amplia aplicada al concepto de gobernanza no solo como consulta de grupos de sociedad sino también como su plena participación en la toma de decisiones (Meier, 2011:163) (Llorens y Costache, 2013: 73). La idea que subyace del concepto más amplio es que haya un intento de llegar a la comunidad a través de un procedimiento que permite la negociación entre una diversidad de opiniones (Carpentier, 2011: 20).

Existen diferentes clasificaciones de participación, pero una de las más interesantes (Azurmendi y Muñoz-Saldaña, 2016) es la de Carpentier (2011):

-Participación en la producción de los medios de comunicación (participación relacionada con el contenido) y en la toma de decisiones 
organizacionales (participación en la estructura). Es aquella puesta en marcha a partir de instituciones como Consejos Asesores, o Consejos de Audiencia.

-Participación a través de los medios de comunicación: autorrepresentación o representación mediada (Azurmendi, MuñozSaldaña, 2016: 804).

\section{La legislación de la participación institucionalizada}

Algunas leyes que regulan las televisiones públicas en la Unión Europea contemplan en su estructura consejos de defensa de los intereses de las audiencias. Se trata de organismos que con diversas nomenclaturas Consejos Asesores, Consejos de la Audiencia, etc.- prevén la participación ciudadana en el funcionamiento de los medios públicos a través de la defensa institucional de sus intereses. Lo hacen fiscalizando el cumplimiento de los principios de programación, la presencia de los intereses minoritarios y los valores de servicio público y, en algunos casos también defendiendo el carácter regional o autonómico del valor público que representan. Destacamos las características más sobresalientes de algunos de estos consejos, atendiendo a su composición, elección, duración del mandato, número de miembros y competencias.

En lo referente a su composición y modelo de elección, en casi todos los casos analizados, estos órganos están formados por representantes de organizaciones sociales, culturales, educativas, económicas, políticas y/o religiosas. En algunos modelos, con el objeto de ampliar la participación directa de los espectadores y audiencias, algunos consejos integran a estos directamente. En la televisión pública de Grecia los Consejos de Control Social, además de representantes de instituciones y colectivos sociales, están formados por voluntarios y televidentes (ERT, 2018).

En France Telévisions (Francia) el denominado Consejo Asesor de los Programas se integra por 28 espectadores, seleccionados anualmente por el Departamento de Investigación y de Comunicaciones. Sus opiniones se incluyen en un informe anual que se hace llegar a los trabajadores y a los altos cargos de la corporación (France Televisions, 2018). 
En Irlanda, RTÉ invita a los miembros del público a enviar sus propuestas para unirse al Consejo de Audiencias. Varias nominaciones adicionales provienen de la Junta de RTÉ. Después de un proceso de selección se eligen a 15 personas que representan una amplia gama de intereses y demandas sociales (RTÉ, 2018).

En BBC (Reino Unido) el proceso de selección de los miembros de los cuatro Consejos de las Audiencias (Inglaterra, Norte de Irlanda, Gales y Escocia) es totalmente abierto. La posibilidad de participación se abre a cualquier ciudadano mayor de 16 años (salvo aquellos con incompatibilidades políticas, funcionarios públicos, o empleados de la $\mathrm{BBC}$ o de otros medios) y se seleccionan en base a seis criterios: comprensión del papel de la BBC como servicio público y respeto a los valores locales; comprensión de la diversidad y necesidades de las audiencias; capacidad de asesorar a la BBC Trust a través de los intereses de los espectadores; experiencia en trabajos colaborativos; compromiso; y residente en la parte de Reino Unido que representa el Consejo de Audiencias (BBC, 2018).

La duración del mandato de estos organismos suele ser de cuatro o cinco años en la mayoría de las televisiones públicas. Caso excepcional es el de France Télévisions en donde los miembros del Consejo Asesor de los Programas son elegidos anualmente o el de la BBC en donde los componentes de los Consejos de las Audiencias lo son durante tres años.

Por sus competencias, se diferencian aquellos organismos con potestades centradas fundamentalmente en el control de la programación (por ejemplo, Consejos Asesores en España o en Francia) de aquellos que también colaboran en actividades de gestión, dirección y financiación (es el caso de los Consejos de las Audiencias de Reino Unido, Irlanda o Austria) (Azurmendi y Saldaña, 2016: 804).

\section{La legislación de la participación a través de los medios}

Carpetiner (2011: 67) señala que la participación a través de los medios ${ }^{7}$ se corresponde "con las oportunidades de la participación mediada en

7 Para un análisis en profundidad del pluralismo en los medios, ver Media Pluralism Monitor, http://cmpf.eui.eu/media-pluralism-monitor/ 
el debate público y con la autorrepresentación en la variedad de los espacios públicos", esto es el denominado derecho de acceso (Azurmendi y Muñoz-Saldaña, 2016: 804).

\subsection{La representación mediada}

En las televisiones públicas la satisfacción de las necesidades e intereses de los grupos sociales minoritarios es uno de los valores principales en el desarrollo de sus funciones propias. Es por ello, por lo que muchas de las leyes que regulan el servicio público audiovisual en los Estados miembros contemplan como misiones de las televisiones públicas proporcionar programas destinados a grupos minoritarios y/o a grupos representativos en la sociedad civil.

Se destacan aquellas leyes que entendemos profundizan más en este aspecto, concretando al menos el número de minorías, grupos o programas y canales donde estos deben estar representados:

En Austria, la Ley 379/1984, de 28 de septiembre, de Radiodifusión de Austria regula el derecho de seis grupos étnicos a una programación en sus idiomas a través de varios soportes (radio, televisión, teletexto y otras tecnologías en base a la viabilidad económica). El control de esta programación se realiza a través del Consejo de la Audiencia (art. 4 (5bis), Ley 379/1984). El Informe de Valor Público de ORF (2015/2016) fiscalizó la emisión de trece programas de radio diferentes dedicados a los seis grupos minoritarios (un promedio de 6,6 a la semana) y un programa de televisión semanal (Media Pluralism Monitor, 2016).

El Estatuto de la Radio y Televisión de Eslovaquia señala en el artículo 5 la obligación de emitir un número mínimo de programas con contenidos regionalmente equilibrados en los idiomas de las minorías nacionales y grupos étnicos que viven en el país.

La Ley, de 20 de octubre de 2010, de la Corporación de Radio Televisión de Eslovenia señala que el servicio público se compromete a crear y retransmitir al menos "un canal de radio y televisión para las comunidades autóctonas italianas y húngaras, emisiones de radio y televisión para las minorías romanís y para las comunidades nacionales de Yugoslavia y miembros de otras comunidades nacionales y étnicas de Eslovenia" (art. 2). 
En Suecia, el servicio público de radiodifusión tiene la obligación de producir programas en cinco lenguajes minoritarios: Sámi, Finnish, Meänkieli, Romani Chib y Yiddish (Media Pluralism Monitor, 2016).

En Reino Unido, la Royal Charter de 2016 de la BBC contiene varios artículos referidos a la obligación de proteger a las comunidades del territorio. Uno de los más extensos es el artículo 6.4 en donde se señala la necesidad de la BBC de "reflexionar sobre la diversidad tanto en sus productos como servicios" y de "precisar y representar auténticamente el estilo de vida de la gente del Reino Unido, y crear conciencia sobre las diferentes culturas y puntos de vista alternativos".

\subsection{La autorrepresentación o derecho de acceso}

El derecho de acceso se define como el "derecho de los grupos sociales y políticos significativos a tiempo de antena en las emisiones de los medios públicos de comunicación social" (Rallo-Lombarte, 2000) (Menezes-Barros, 2017: 71). En las distintas regulaciones que lo reconocen, se denomina o bien como derecho de acceso o bien como derecho de antena (Menezes-Barros, 2017: 71). Solo las Constituciones de Chipre (art. 171), España (art. 20), Portugal (art. 40) y Rumanía (art. 31) en la UE contemplan este derecho, siendo la norma fundamental de Chipre la que lo hace de forma más amplia y concreta ${ }^{8}$ (MenezesBarros, 2017). Algunas de las leyes que regulan los medios audiovisuales públicos en la UE desarrollan este derecho de distintas maneras. Se señalan aquellas que, o bien por la titularidad del derecho, o bien por sus mecanismos, son transcendentales para elaborar nuestras recomendaciones:

En Alemania, las leyes que regulan cada uno de los organismos que componen ARD y el Estatuto de ZDF (art.11) prevén en su mayoría un derecho de emisión para anuncios oficiales gubernamentales, para las iglesias y principales comunidades religiosas y -antes de las elecciones - para los partidos políticos y grupos electorales. En la

\footnotetext{
${ }^{8}$ Artículo 171 de la Constitución de Chipre: El tiempo reservado a los programas para la comunidad turca en la radiodifusión no será inferior de setenta y cinco horas por cada semana (...) En la televisión se asignarán tres días de emisión a los programas para la comunidad turca por cada diez días consecutivos (MenezesBarros, 2017)
} 
misma línea, se encuentran las normas que regulan la radiotelevisión pública de otros Estados miembros como en Bulgaria (Ley n³8, de 24 de noviembre de 1998, sobre Radio y Televisión, arts. 49-55); Lituania (Ley 102/2319, de 08 de octubre de 1996, sobre la Radio y la Televisión de Lituania, art. 5); Eslovenia (Ley, de 20 de octubre de 2010, de la Corporación de Radio y Televisión, art. 12); Eslovaquia (Ley, de 15 de diciembre de 2010, de Radio y Televisión de Eslovaquia, art. 5).

En Bélgica, VRT y BRTF desarrollan de forma pormenorizada el derecho de acceso (Montoro-Fraguas, 2007). Se regula en VRT el tiempo dedicado las emisiones. El Decreto, de 27 de marzo de 2009, relativo a la radiodifusión y televisión señala el derecho de los grupos políticos a 15 minutos cada mes (art. 34) y de los grupos sociales y económicos a un programa de televisión de al menos 30 minutos cada dos semanas o 15 cada semana y cuatro minutos en radio semanales. En ellos participarán los representantes en el Consejo Socio Económico de Flandes (art. 29). La normativa de RTBF (Decreto, de 14 de julio de 1997, sobre Radio-Televisión Belga de la Comunidad Francesa) señala la preferencia de las organizaciones religiosas a emitir los domingos, mientras que las laicas tendrán derecho de emisión aquel día que ellas consideren festivo para el grupo que representen (Montoro-Fraguas, 2007: 88-89).

El derecho de acceso recogido en el art. 20 de la Constitución Española se desarrolla en la mayoría de las leyes que regulan las radiotelevisiones públicas en España (estatal y autonómicas), aunque con ciertas diferencias. En general, se hace referencia a la necesidad de garantizar el derecho a través de espacios específicos y, en algunas normativas, a los medios técnicos y humanos necesarios. La aprobación de este derecho la suele realizar el Consejo de Administración, oído el Consejo Asesor o bajo su fiscalización.

Como novedades en las normativas autonómicas en España, destacan las regulaciones de la corporación pública valenciana y canaria que incorporan un extenso artículo señalando además del derecho de los grupos sociales y políticos, la celebración de convenios de colaboración con productores de bienes culturales y audiovisuales locales. A esto se añade, en estas leyes, la obligación del Consejo de Administración en el plazo de seis meses de aprobar un reglamento sobre el derecho de 
acceso, cuestión que también prevé la normativa asturiana y que ya se ha publicado en la corporación estatal de RTVE.

El Decreto n 2009-796, de 23 de junio, que regula France Télévisions, en Francia, destaca por incluir el derecho de acceso ('L'expression') del Parlamento y las asambleas territoriales y locales (art. 45), de las formaciones políticas (art. 46) y de las organizaciones sindicales y profesionales (art. 49), considerando representativo cualquier sindicato afiliado a una organización en el plano nacional.

En Italia, la Ley de 22 de febrero 28/2000 "Disposiciones para la paridad del acceso a los medios de información durante la campaña electoral y referéndum para la comunicación política" regula tanto "el acceso electoral de los grupos políticos como el acceso de estos grupos a los medios de información fuera de campaña electoral" (MontoroFraguas, 2007: 100), en todos los medios de comunicación.

La Ley italiana de 14 de abril 103/1975 "Nueva norma en materia de difusión radiofónica y televisiva" regula en el artículo 6 el derecho de acceso de partidos y grupos parlamentarios, sindicatos, organizaciones locales y nacionales, confesiones religiosas, movimientos políticos, organismos y asociaciones políticas y culturales, asociaciones de movimientos cooperativos jurídicamente reconocidos, grupos étnicos y lingüísticos y otros grupos de interés social. Se reservan para ellos tiempos no inferiores al 5\% de las horas totales de la programación televisiva y del 3\% de la programación radiofónica.

Una de las televisiones donde se ha legislado de forma más amplia este derecho es RTP en Portugal. la Ley 27/2007, de 30 de junio de Televisión, regula (art. 59) de una forma extensa el derecho de antena en el servicio público de televisión, detallando pormenorizadamente los titulares del mismo y los tiempos de emisión de cada uno de ellos:

a. Diez minutos por partido representado en la Asamblea de la República, aumentados en 30 segundos por cada diputado electo.

b. Cinco minutos por partido no representado en la Asamblea de la República con participación en las últimas elecciones legislativas, aumentados en 30 segundos para cada 15.000 votos obtenidos. 
c. Sesenta minutos para el Gobierno y para los partidos representados en la Asamblea de la República que no forman parte del mismo, en proporción a su representatividad.

d. Noventa minutos para las organizaciones sindicales, organizaciones profesionales y representativas de las actividades económicas y cincuenta minutos para las asociaciones en defensa del medio ambiente, de los consumidores y de los derechos humanos, en proporción a su representatividad.

e. Quince minutos para otras entidades que tengan el derecho de antena atribuido por ley.

Es de relevancia el hecho de que se obligue por ley que los tiempos de antena deben ser emitidos en el servicio de televisión de cobertura nacional de mayor audiencia inmediatamente antes o después del principal informativo difundido entre las 19.00 y las 22.00 horas (art. 61). Se regula también el procedimiento de solicitud de este derecho al menos 15 días antes de la transmisión (art. 61). Se señalan como límites al derecho de antena los sábados, domingos y festivos nacionales, siendo suspendido un mes antes del inicio del período de campañas electorales (art. 60). En estos períodos se aplica la legislación electoral correspondiente (art. 63).

\section{Sugerencias para legislar la participación ciudadana}

El análisis realizado muestra diferentes patrones en las leyes que regulan las televisiones públicas sobre participación. Una vez obtenidos los resultados, lo que se ofrece es un modelo que consideramos podría ser positivo a la hora de legislar este derecho, en especial en aquellas televisiones que no lo contemplan, lo hacen de forma escueta o son objeto de críticas por la escasa efectividad de la participación social. No se pretende establecer un único patrón, conocedores del diferente contexto histórico, social y económico, de cada medio público, sino solamente ofrecer unas pautas para mejorar la regulación, en el caso de ser posible.

- La participación institucionalizada. Es conveniente que se legisle la creación de consejos institucionales de participación ciudadana. Por su composición, podrían ser órganos formados por representantes 
sociales, económicos y culturales elegidos a través de una convocatoria pública pero también por espectadores y miembros de la audiencia, seleccionados en base a criterios de profesionalidad, compromiso e independencia. Su mandato debería tener una duración que no coincidiera con la legislatura. Finalmente, entre sus competencias debería estar presente el control de la programación, pero también de la financiación, en especial, de aquellas partidas referidas al servicio público. Es recomendable que, en el caso de no tener potestad vinculante, al menos sí hubiera un informe motivado ante los órganos de fiscalización, en los supuestos de no cumplirse sus recomendaciones.

- Representación mediada. Es importante que las leyes que regulan el servicio público audiovisual de cada país prevean programas destinados a las minorías y grupos sociales representativos. Se recomienda que se refleje como una medida, tanto desde el punto de vista cuantitativo como desde el cualitativo, definiendo los colectivos titulares de este derecho. En aquellos Estados con más de una lengua, es necesario prever instrumentos que canalicen una programación en todos los idiomas existentes.

- Autorrepresentación o derecho de acceso. Es pertinente regular este derecho, indicando nítidamente la titularidad del mismo, y el momento de su ejercicio. Se recomienda que se legisle a favor de introducir espacios en las radiotelevisiones públicas (servicios lineales y no lineales) en primetime, ofreciendo los recursos humanos y técnicos pertinentes para su ejercicio.

\section{Referencias bibliográficas}

Azurmendi, A., Llorens, C, López-Vidales, N. y Bas-Portero, J.J. (2015). La participación del público como valor añadido de servicio público para la televisión de proximidad. Estudio de caso de la La noche de..., en ETB2, Revista Latina de Comunicación Social, 70, 490-518.

Azurmendi, A. y Muñoz-Saldaña (2016). Participación del público en televisiones públicas autonómicas: una propuesta partir de la reforma 2016 de la BBC, El profesional de la información, 5(25), 1699-2407. 
BBC (2018). Descripción de los miembros de los Consejos de la Audiencia en la BBC. Recuperado el 29 de mayo de 2018 de http://downloads.bbc.co.uk/bbctrust/assets/files/pdf/audienc e_councils/ac_role_description.pdf

Carpentier, N. (2011). Media and participation: A site of ideologicaldemocratic struggle. Bristol: Intellect Books.

ERT (2018). ¿Qué son los Consejos de Control Social?. Recuperado el 29 de mayo de 2018 de http://polites.ert.gr/ti-einai-tasymvoulia/

Filgueiras, F. (2011). Além da transparencia: Accountability e política da publicidade, Lúa Nova (84), 65-94.

France Télévisions (2018). El Consejo Asesor de los Programas. https://www.francetelevisions.fr/le_Conseil_consultatif_des_p rogrammes

García-Avilés, J.A. (2011). Dimensiones y tipología de las actividades de participación de la audiencia en la televisión pública, Ámbitos, 20, 175-195.

Hargittai, E. y Walejko, G. (2008). The participation Divide: Content Creation and Sharing in the Digital Age, Information, Communication and Society, 11 (2), 239-256.

Hasebrink, U. (2011). Giving the Audience a Voice: The Role of Research in Making Media Regulation More Responsive to the Needs of the Audience, Journal of Information Policy, (1), 321-336.

López-Cepeda, AM (2017). La gobernanza en la radiotelevisión pública europea: El modelo español. En Túñez, M., Campos, F. y Silva, A. (coords.), Estudios sobre legislación, financiación e innovación en la televisión pública (41-58). La Laguna (Tenerife), Latina: Cuadernos Artesanos de Comunicación.

López-Cepeda, AM. Y Manfredi-Sánchez, J.L. (2018). Transparencia y medios de comunicación de servicio público. En López, M., Campos, F., López P. y Rivas, F. (Eds.), La comunicación en la nueva sociedad digital (413-433). Venezuela: Centro de Publicaciones. 
López-López, P.C., Puentes-Rivera, I. y Rúas-Araújo, J. (2017).

Transparencia en televisiones públicas: desarrollo de indicadores y análisis de los casos de España y Chile", Revista Latina de Comunicación Social, 72, 253-272.

Llorens, C. y Costache, A. (2013). La gobernanza como marco teórico para el estudio del pluralismo de medios, Trípodos, 32, 63-76.

Media Pluralism Monitor (2016). Results by Country. http://cmpf.eui.eu/media-pluralism-monitor/mpm-2016results /

Meier, W.A. (2011). From Media Regulation to Democratic Media Governance. En: Trappel, J. [et al.] (eds.) Media in Europe Today (81-103), Bristol: Intellect Ltd.

Menezes-Barro, Ch. (2017). El derecho de acceso de los grupos sociales a los medios de comunicación. Especial consideración del ordenamiento jurídico brasileño. Tesis doctoral. Madrid: Universidad Complutense de Madrid.

Montoro-Fraguas, A. (2007). El derecho de acceso a la radiotelevisión pública. Madrid: Dykinson.

O’Donnell, G. (2004). Accountability horizontal: la institucionalización legal de la desconfianza política, Revista Española de Ciencia Política, (11), 11-31.

Rallo-Lombarte, A. (2000). Pluralismo informativo y constitución. Madrid: Tirant lo Blanch.

RTÉ (2018). How RTÉ is run. Recuperado el 29 de mayo de 2018, de https://www.rte.ie/about/en/how-rte-isrun/2015/0518/701954-audience-council/ 


\section{Legislación}

\section{a. Políticas europeas}

Council of Europe Recommendation CM/Rec (2012)1 of the Committee of Ministers to Member States on public service media governance.

\section{b.Legislación por Estados miembros ${ }^{9}$}

Alemania ${ }^{10}$ : Tratado de ZDF, del 31 de agosto de 1991, Recuperado el 29 de mayo de 2018 de https://www.zdf.de/zdfunternehmen/zdf-rechtsgrundlagenund-vorschriften-100.html

Austria: Ley 379/1984, de 28 de septiembre, de Radiodifusión de Austria. Recuperado el 29 de mayo de 2018 de https://www.ris.bka.gv.at/GeltendeFassung.wxe?Abfrage $=\mathrm{Bu}$ ndesnormen\&Gesetzesnummer $=10000785$

Bélgica: Decreto de 27.6.1986 sobre el Centro Belga de Radio y Televisión de la Comunidad de Habla Alemana. Recuperado el 29 de mayo de 2018 de https://u.brf.be/

Bélgica: Decreto de 14 de julio de 1997 sobre Radio-Televisión Belga de la Comunidad Francesa. Recuperado el 29 de mayo de 2018 de http://www.csa.be/documents/2474

Bélgica. Decreto de 27 de marzo de 2009, relativo a la radiodifusión y televisión. Recuperado el 29 de mayo de 2018 de https://cjsm.be/media/themas/mediadecreet/decreet-van-27maart-2009-betreffende-radio-omroep-en-televisie

\footnotetext{
${ }^{9}$ Si bien se analizaron las leyes que regulan todas las radiotelevisiones públicas en la UE, solo se referencian aquellas que se citan directamente en el texto.

${ }^{10}$ Se analizaron las leyes que regulan las corporaciones que conforman la ARD (Bayerischer Rundfunk, Hessischer Rundfunk, Mitteldeutscher Rundfunk, Norddeutscher Rundfunk, Radio Bremen, Rundfunk Berlin-Brandenburg, Saarländischer Rundfunk, Südwestrundfunk, Westdeutscer Rundfunk, Deutsche Welle, Deutschlandradio).
} 
Bulgaria: Ley n $\mathrm{n}^{\circ}$ 38, de 24 de noviembre de 1998, sobre Radio y Televisión. Recuperado el 29 de mayo de 2018 de https://p.bnt.bg/z/a/zakon-za-radioto-i-televiziyata-516.pdf

Eslovaquia: Ley de 15 de diciembre de 2010, de la Radio y Televisión de Eslovaquia. Recuperado el 29 de mayo de 2018 de https://www.rtvs.org/o-rtvs/legislativa

Eslovenia: Ley, de 20 de octubre de 2010, de la Corporación de Radio y Televisión, de Eslovenia. Recuperado el 29 de mayo de 2018 de http://www.mk.gov.si/en/legislation_and_documents/

España $^{11}$ : Ley 17/2006, de 5 de junio, de la Radio y Televisión de Titularidad Estatal. Recuperado el 29 de mayo de 2018 de https://www.boe.es/buscar/doc.php?id=BOE-A-2006-9958

Francia: Decreto n ${ }^{\circ}$ 2009-796 del 23 de junio de 2009 que regula la compañía France Televisions. Recuperado el 29 de mayo de 2018 de

https://www.legifrance.gouv.fr/affichTexte.do?cidTexte=JORF TEXT000020788471\&categorieLien $=\mathrm{id}$

Italia. Ley no 73 , de 14 de abril de 1975, Nueva norma en materia de difusión radiofónica y televisiva. Recuperado el 29 de mayo de 2018 de http://digilander.libero.it/massimo_miranda/rtv_L10375.htm

Italia. Decreto Legislativo, $\mathrm{n}^{\mathrm{o}}$ 177, de 31 de julio de 2005, Texto único de los servicios de medios audiovisuales y radiofónicos. Recuperado el 29 de mayo de 2018 de http://www.gazzettaufficiale.it/eli/id/2005/09/07/005G0206/s g

Irlanda. Ley de radiodifusión de 2009. Recuperado el 29 de mayo de 2018, de

11 Se analizaron todas las leyes que regulan las radiotelevisiones públicas autonómicas en España (Andalucía, Aragón, Asturias, Cataluña, Castilla-La Mancha, Comunidad Valenciana, Extremadura, Galicia, Islas Baleares, Islas Canarias, Madrid, Murcia, País Vasco). www.forta.es 
http://www.irishstatutebook.ie/eli/2009/act/18/section/96/en acted/en/html\#sec96

Lituania: Ley 102/2319, de 08 de octubre de 1996, sobre la Radio y la Televisión de Lituania. Recuperado el 29 de mayo de 2018 de https://www.lrt.lt/apie-lrt/lrt/istatymas

Portugal. Ley 27/2007, de 30 de julio, de Televisión. Recuperado el 29 de mayo de 2018 de http://media.rtp.pt/empresa/wpcontent/uploads/sites/31/2015/11/Lei-n\%C2\%BA-27-200730-de-Junho.pdf

Reino Unido. Royal Charter, 2016. Recuperado el 29 de mayo de 2018 de

http://www.bbc.co.uk/bbctrust/governance/regulatory_framew ork/charter_agreement.html

\section{Reconocimientos de la investigación}

- Los resultados de este artículo forman parte de las actividades de difusión del proyecto del Programa estatal de Fomento de la Investigación Científica y Técnica de Excelencia, subprograma estatal de Generación de Conocimiento del Ministerio de Economía y Competitividad de España sobre "Indicadores de gobernanza, financiación, rendición de cuentas, innovación, calidad y servicio público de las RTV europeas aplicables a España en el contexto digital" (Referencia CSO2015-66543$\mathrm{P})$. 


\title{
Monitorización de las radiotelevisiones públicas de España y Portugal en Facebook
}

\author{
María-Magdalena Rodríguez-Fernández \\ Eva Sánchez-Amboage \\ Universidad de A Coruña
}

PARA CITAR: Rodríguez-Fernández, M.-M. y Sánchez-Amboage, E. (2018). Monitorización de las radiotelevisiones públicas de España y Portugal en Facebook. En Pérez-Seijo, S., Rodríguez-Castro, M. y Túñez-López, M. (Eds.), Debates sobre valores e indicadores del servicio audiovisual público en Europa (pp. 143-155). Cuadernos Artesanos de Comunicación, cac142. La Laguna (Tenerife): Latina. DOI: $10.4185 / \operatorname{cac} 142$

\section{Resumen}

La crisis económica iniciada en el año 2007 ha tenido importantes repercusiones en el ámbito de la financiación de las radiotelevisiones públicas europeas. Los dos países de la Unión Europea que más recortes presupuestarios han sufrido entre 2010 y 2014 están situados en la Península Ibérica: España y Portugal. En este sentido, los efectos de la crisis unido a los cambios acaecidos en el entorno, consecuencia de la irrupción de las tecnologías de la información y comunicación (TICs), han propiciado la aparición de nuevos modelos de comportamiento, tanto por parte de las televisiones a la hora de producir contenidos, como de los usuarios/audiencias, en el momento de consumirlos. Ante esta situación surgen nuevos escenarios liderados por los medios sociales los cuales se han convertido en plataformas 
fundamentales para informar, difundir, comunicar y por ende fomentar la interactividad con sus respectivas audiencias ante aquellos acontecimientos que son noticia. En este capítulo se ha querido, por tanto, ejemplificar tal situación, a través del uso que realizan las radiotelevisiones públicas de España y Portugal, del medio social Facebook con el fin de identificar los acontecimientos que han impactado en sus usuarios y conocer sus reacciones.

Palabras clave: radiotelevisiones públicas europeas; crisis; medios sociales; Facebook.

\section{El proceso de convergencia mediática en las radiotelevisiones públicas}

Desde sus orígenes la televisión ha sido considerada como el medio de comunicación por antonomasia, bien es cierto que en los últimos años la tecnología ha evolucionado y la forma de consumir contenidos ha cambiado.

Este proceso de convergencia mediática ha propiciado el consumo de contenidos a través de múltiples canales (páginas web, redes sociales, etc.) y de múltiples dispositivos (televisión convencional, ordenador, móviles, etc.), lo que ha desembocado en la necesidad de que las empresas adapten su distribución a formatos mixtos.

En los últimos años los medios sociales han experimentado un notable crecimiento, al convertirse en herramientas clave para el cambio social, se postulan, así como un gran aliado, no sólo para las corporaciones, sino también para los propios medios y soportes, que encuentran en los social media un espacio de comunicación, promoción y difusión de contenidos (Hidalgo y Segarra, 2017).

En el ámbito televisivo, han penetrado con tal fuerza, hasta el punto de transformarse en plataformas de comunicación idóneas capaces de fomentar la interactividad del medio con el espectador y contribuir así, a mejorar la divulgación y promoción de los contenidos de los soportes tradicionales. Según Campos (2016) los medios sociales son imprescindibles en las estrategias de comunicación de las televisiones públicas. 
El hecho de disponer y gestionar de forma adecuada una página o un perfil en este tipo de medios influye positivamente en el posicionamiento de cualquier empresa de comunicación audiovisual, al propiciar, entre otros, los siguientes beneficios:

- Interactividad y realimentación. Los medios sociales, a diferencia de la televisión tradicional, permiten el contacto con la audiencia en todo momento. De esta forma se consigue un trato personalizado, donde el usuario es el protagonista. Pasar de un canal unidireccional a uno bidireccional permite la captación y la fidelización de clientes, debido a que se pueden desarrollar acciones y contenido de interés para los mismos. En muchas ocasiones, las fanpages se convierten también en un medio de atención al cliente, donde el usuario busca una respuesta rápida a su consulta; algo que seguramente por la vía offline, implicaría más tiempo.

- Imagen de marca. Las redes sociales, si se emplean de forma adecuada, pueden llegar a posicionar en la mente del consumidor a las radiotelevisiones públicas. Para ello es preciso que los gestores sean conscientes de la importancia que supone el hacer un uso eficiente de las mismas, ya que incidiría en la visibilidad y por ende en un mayor reconocimiento de la marca.

- Información sobre el cliente. La comunidad online creada en un medio social es una fuente de información para la empresa. El nombre, la localización, la dirección de correo electrónico, los gustos, preferencias e intereses, son algunos de los datos que un canal de televisión obtiene de sus seguidores; información que puede ser empleada para adaptar la programación de las radiotelevisiones públicas a lo que su público demanda.

- Reducción de costes innecesarios. Lo anterior provoca que la empresa tenga información clara y concisa sobre sus seguidores, dicho conocimiento permite establecer segmentos de clientes, con unas necesidades y preferencias concretas y adaptar así la programación de la cadena a sus gustos.

- Constante actualización. Los medios sociales facilitan la compartición de información actualizada en todo momento, ofrecen la ventaja de adaptarse a cualquier situación y posibilitan distintas estrategias según las circunstancias. En el sector audiovisual contar con plataformas que 
conecten con la audiencia de forma paralela a la retransmisión de un determinado programa de televisión, o "twittear" sobre una noticia de última hora, es una realidad.

- "Contagio" por otros usuarios. Las redes sociales crean el escenario perfecto para compartir información. Las personas navegan entre comentarios, consejos, opiniones o recomendaciones de productos o servicios que otros han consumido. Lo esencial es que la mayor parte de esas personas forman parte de la red social más directa del usuario en cuestión, con lo cual, otorgarán más credibilidad al contenido. El hecho de que un/a amigo/a comparta información sobre el programa de televisión que está viendo o ha visto, provocará más interés que si lo hace una persona/marca desconocida para el usuario.

A pesar de las numerosas ventajas que los medios sociales pueden ofrecer a las cadenas públicas, el salto al mundo digital se produce con mayor lentitud, dado que la financiación depende sobre todo de los presupuestos generales del estado (Hidalgo y Segarra, 2017).

\section{El sector de las radiotelevisiones públicas marcado por la crisis económica}

Las radiotelevisiones públicas europeas comenzaron a funcionar en la década de los cincuenta y sesenta del siglo pasado con el fin de capitalizar los valores democráticos y sentar las bases del servicio público de radiodifusión (Fernández y Valencia, 2015), sin embargo, desde entonces las cosas han cambiado.

La crisis económica iniciada en 2007 en Europa afectó al sector audiovisual de forma importante. Desde el año 2010 hasta 2014 los presupuestos anuales conjuntos para las radiotelevisiones públicas, tanto estatales como regionales, se habían reducido en 486 millones de euros, lo que en porcentajes suponía una evolución negativa del (1,44\%). En el caso de España, los recortes presupuestarios sufridos, durante dicho periodo, se situaron en el $35,2 \%$, mientras que para Portugal en el 30,9\%, posicionándose así, ambos países, entre los más afectados por la crisis de la Unión Europea, en lo que a reducción de presupuestos se refiere (Campos, 2016).

En este sentido, las tendencias de este sector marcadas por la crisis económica-financiera, así como, por la transformación tecnológica, 
han derivado en una reestructuración de las radiotelevisiones públicas (Campos, 2013).

La aparición, por un lado, de una mayor competencia, la cual exige la necesidad de adaptación y ampliación de su oferta para mantener el nivel de competencia con el sector privado (Fernández y Valencia, 2015), y por otro, la fragmentación de las audiencias, han contribuido a que muchos, se cuestionen la necesidad de que existan las radiotelevisiones públicas a pesar de la función social que desempeñan. Ofrecer contenidos de radio y televisión a los usuarios, con el fin de cumplir los estándares de calidad informativa exigida y, por ende, la misión de servicio público que ostentan, ha de ser la misión principal. Motivo por el cual la adecuación de las radiotelevisiones públicas a los entornos digitales, donde los medios sociales acaparan gran relevancia, supone una gran oportunidad para adaptarse a los cambios tecnológicos acaecidos en el entorno y mitigar por tanto los recortes presupuestarios a los cuales se han visto sometidos en los últimos años.

\section{Monitorización del medio social Facebook}

La monitorización en los medios sociales se puede definir como el acto de analizar distintas páginas o perfiles a través del uso de herramientas capacitadas para el rastreo y almacenaje de diferentes ítems que, en su conjunto, permiten conocer el posicionamiento de una determinada página o perfil en los medios sociales.

En lo que respecta a los indicadores para monitorización de medios sociales cabe precisar que han evolucionado con el tiempo y con las necesidades de cada momento. Los ítems que se utilizaban a principios de la segunda década del siglo XXI para analizar redes sociales como Facebook, por aquel entonces la más utilizada a nivel mundial al igual que ocurre en la actualidad, han experimentado cambios significativos para adaptarse a la reciente actividad de los mismos.

Internet República (2012) recomendaba así el análisis de las siguientes variables para conocer la situación de una determinada página en Facebook: fans (Número total de fans de una marca), interacciones (cantidad de fans que hablan de la marca), pestañas (presencia o no), aplicaciones (presencia o no), actualización del canal (media óptima de publicaciones de 3 a 5 semanales), tipo de contenido (propio, ajeno, mixto) y calidad del contenido (relevancia del contenido para el 
público). Asimismo, la agencia anterior establecía que el seguimiento de un sitio de redes sociales tenía que ser, como mínimo de 3 meses.

En el año 2018, algunos de los parámetros que en su momento planteaba Internet República (2012) quedan desfasados por la evolución de los medios sociales en general y de la red social Facebook en particular. Por ejemplo, al prestar atención a la actualización del canal, hoy en día, cualquier página o perfil debería de superar la recomendación de 3 y 5 publicaciones, no a la semana, sino al día.

Estudios recientes sobre el análisis de medios sociales, exponen otros indicadores para la monitorización. Muestra de ello es el modelo PRGS propuesto por IAB Spain Research con el fin de llevar a cabo el "Estudio actividad de las marcas en medios sociales" durante los años 2012 y 2016 y utilizado, además, por otros investigadores como, Giraldo y Martínez (2017).

Dicho modelo PRGS está formado por la agrupación de las siguientes variables: Presencia, Respuesta, Generación y Sugerencia.

Presencia (P): se relaciona con el número de publicaciones que la enseña realiza en la página, es decir, $\mathrm{P}=\mathrm{N}^{\mathrm{o}}$ post. La variable presencia se mide en valor absoluto. Sin embargo, las variables respuesta, generación y sugerencia se expresan en valor relativo, al depender del número de fans de la página (Giraldo y Martínez, 2015, 2017; Giraldo y Sánchez, 2014)

Respuesta (R): se identifica con la actividad del usuario y se vincula al número de me gusta que los mismos generan ante las publicaciones de la marca, es decir, $\mathrm{R}=\mathrm{Me}$ Gusta/n ${ }^{\circ}$ fans.

Generación (G): se corresponde con la actividad del usuario y viene dada por el número de comentarios que los mismos realizan ante las publicaciones de la marca, es decir, $G=$ Comentarios $/ \mathrm{n}^{\circ}$ fans.

Sugerencia (S): se refiere a la actividad del usuario y alude al número de comparticiones que los mismos generan ante las publicaciones de la marca, es decir, $\mathrm{S}=$ Compartir $/ \mathrm{n}^{\circ}$ fans.

Para la monitorización de parámetros en redes sociales existe un número de herramientas amplio, debido a la rapidez con la que éstas aparecen y desaparecen. Además, su uso es cambiante, al depender de 
la utilización que se les dé: estudios de carácter empresarial, investigación, interacción, comparación de la competencia, etc.

Tras la experiencia con varias herramientas, Fanpage Karma (http://www.fanpagekarma.com/) aporta mejores resultados que otros instrumentos de características similares debido a que posibilita el análisis de medios sociales y la monitorización de varias redes Facebook, Twitter, YouTube, Google + e Instagram y ofrece de forma fácil e intuitiva resultados visuales, con claridad y rigurosidad. Fanpage Karma ha sido utilizada previamente en otras investigaciones, por autores como: Rodríguez, Rodríguez, Viñán y Martínez (2016); Sánchez, Ludeña, Viñán y Martínez (2015).

\section{Las reacciones en Facebook de los usuarios de RTVE y RTP ante acontecimientos sociales}

En el caso concreto de las radiotelevisiones públicas de España y Portugal, al aplicar el modelo PRGS, se obtiene una radiografía que permite conocer la actividad desarrollada durante 1 año y 5 meses, desde el 2017 hasta la actualidad (01/01/2017-31/05/2018) en sus páginas de Facebook con el fin de identificar principalmente con qué tipo de contenido reaccionan los usuarios de las mencionadas páginas.

- $\quad$ España (RTVE) https://www.facebook.com/rtve/

- Portugal (RTP) https://www.facebook.com/rtp

El motivo de focalizar, en este caso, la monitorización en Facebook se debe a que es la red social con mayor número de usuarios a nivel mundial, concretamente, según datos de Statista, en el mes de abril de 2018, poseía más de 2.200 millones de usuarios. Asimismo, en el caso de España y Portugal, Facebook se posicionaba con un $94 \%$ y un $96 \%$, respectivamente, como la red social más visitada en 2017 (Statista, 2018).

Para facilitar la interpretación de los resultados, al igual que en los trabajos de (Giraldo y Martínez, 2017), se ha optado por calcular el valor medio de cada una de las variables en aras de realizar un estudio comparativo de la actividad en Facebook de las dos televisiones públicas.

A continuación, se muestran cuatro figuras que representan la Presencia, Respuesta, Generación y Sugerencia de cada una de las fanpages. 
Figura 1. Presencia de las páginas de Facebook de RTVE y RTP

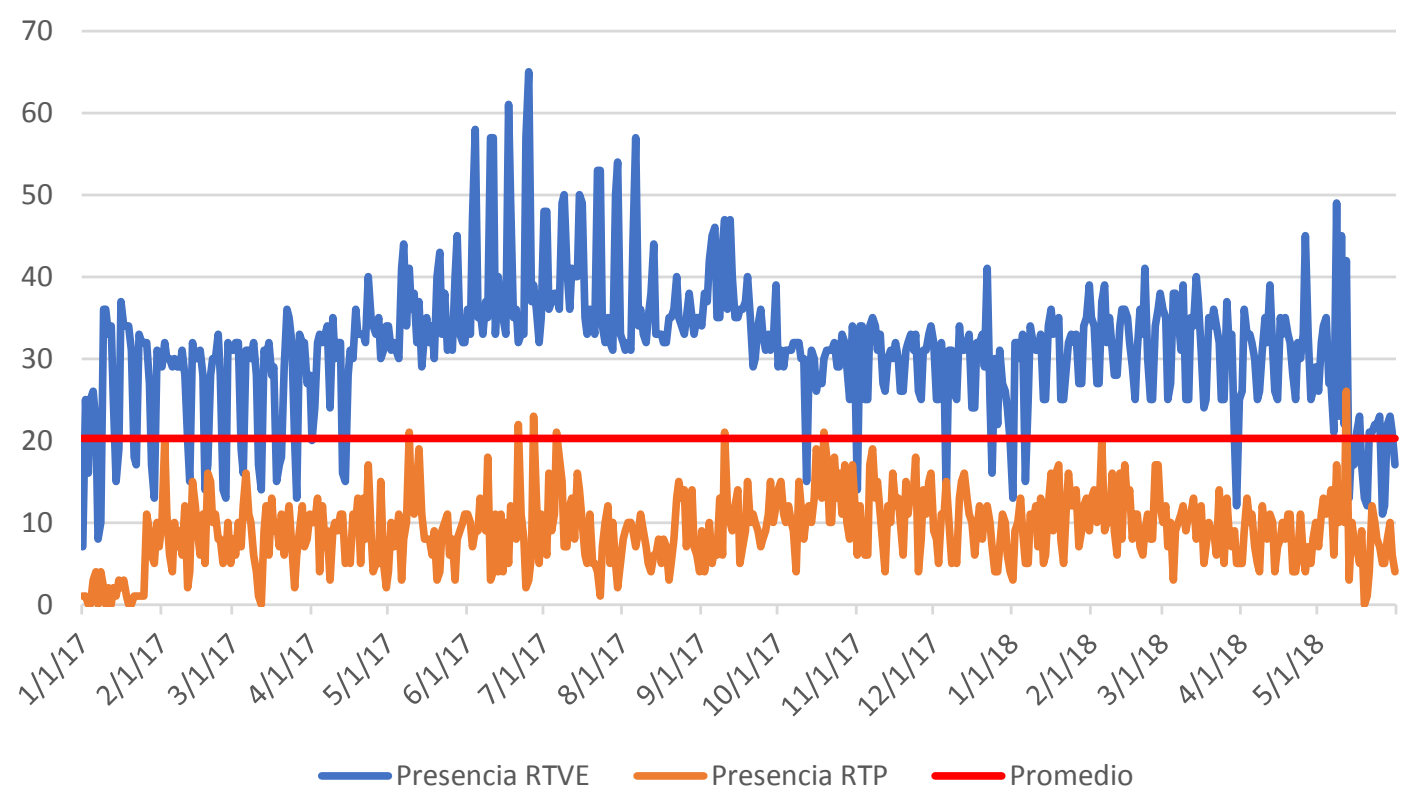

Tal y como se ha comentado la presencia alude a las publicaciones. En este sentido, en la Figura 1 se aprecia que la página que realiza un número más elevado de publicaciones y se sitúa de forma significativa, durante el período de análisis, por encima de la media (20,26 publicaciones) es RTVE. El punto máximo se alcanza con las 65 publicaciones registradas el 25/06/2017. Al contrario, el 01/01/2017 (7 posts), se corresponde con el día de menor actividad por parte de la RTVE. En ambos extremos el contenido de los posts tiene relación con la actualidad del momento o con la información sobre cuestiones de la propia cadena de televisión.

Al observar nuevamente la Figura 1 destaca el período comprendido entre abril 2017 y septiembre de 2017, puesto que de forma prolongada es cuando RTVE desarrolla su máxima actividad en lo que respecta al número de publicaciones en Facebook.

En el caso de RTP sobresale el 12/05/2018 con un total de 26 publicaciones. Cabe explicar que los posts realizados ese día tienen relación con el festival de Eurovisión, celebrado en el año 2018 en Portugal. Se evidencia, por tanto, una de las ventajas comentadas en este capítulo, la posibilidad de interactuar con la audiencia de un programa, de forma paralela a su retransmisión. 
Asimismo, cabe mencionar que en los dos casos (RTVE y RTP) existe una marcada variación en cuanto al número de publicaciones de un día a otro, aspecto que se refleja en el gráfico con pronunciadas subidas y bajadas.

Figura 2. Respuesta de las páginas de Facebook de RTVE y RTP

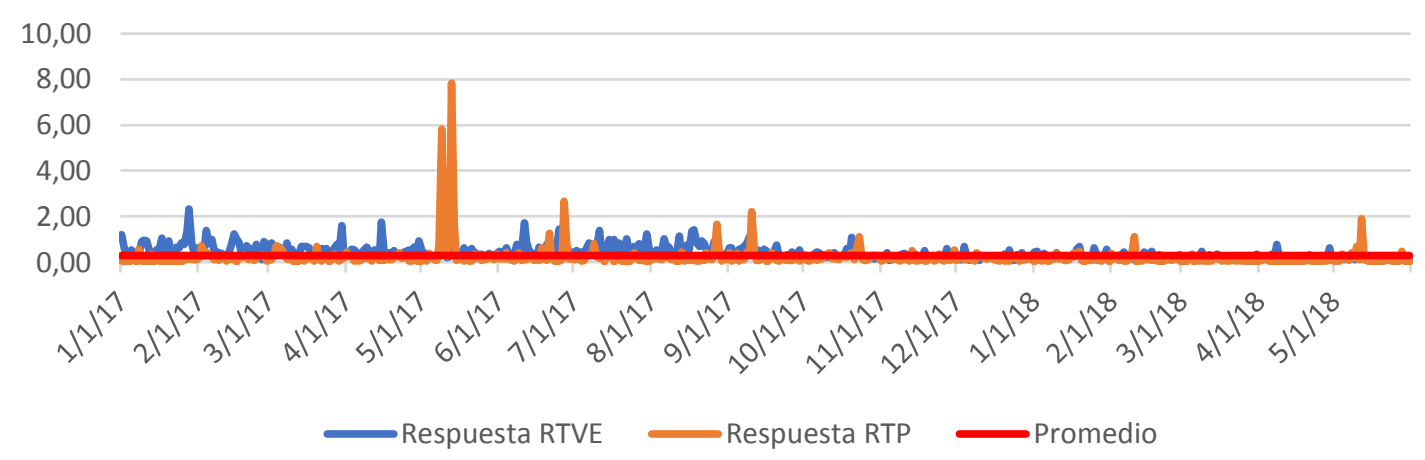

Fuente: Elaboración propia

Otra de las variables del modelo PRGS es la respuesta, la cual aparece representada en la Figura 2, cuyo promedio de ambas televisiones es de 0,31. El gráfico muestra dos aspectos fundamentales, por un lado, RTVE con el paso del tiempo (concretamente a partir de octubre de 2017) pierde tasa de respuesta y en los últimos meses se sitúa en niveles similares a los de la RTP, aun contando con un mayor número de fans (superior a 680.000 en el caso de RTVE y a 500.000 en RTP).

Por otro lado, destaca la tasa de respuesta del 13/05/2017 que alcanza RTP, coincidiendo nuevamente con la celebración de Eurovisión, justamente en el año que Portugal ganaba este festival. Parece por tanto evidente que dicha tasa en ese momento alcance picos de 7,81 al establecerse una relación directa entre el programa de televisión y Facebook como canal de comunicación.

En relación a la variable de generación se vuelve a producir la misma situación que en casos anteriores, en términos generales, RTVE presenta una tasa más alta que la RTP. El promedio de la tasa de generación para ambas fanpage, se sitúa en el 0,04. En la Figura 3 sobresale también la tasa de generación de 1,93, el día 17/08/2017 que supone el valor más elevado de todo el período analizado. En esta ocasión los usuarios de la página de Facebook de RTVE realizaron multitud de comentarios consecuencia de los atentados de las Ramblas 
de Barcelona. De nuevo, se constata que los medios sociales han servido de soporte a los comentarios de la audiencia.

Al continuar con el análisis de la RTVE destacan otros dos acontecimientos, el 22/03/2017 (0,57 tasa de generación) coincidiendo con la retransmisión en directo de una entrevista con el compositor argentino Abel Pintos y el 13/05/2017 (0,45 tasa de generación) nuevamente con el festival de Eurovisión.

Figura 3. Generación de las páginas de Facebook de RTVE y RTP

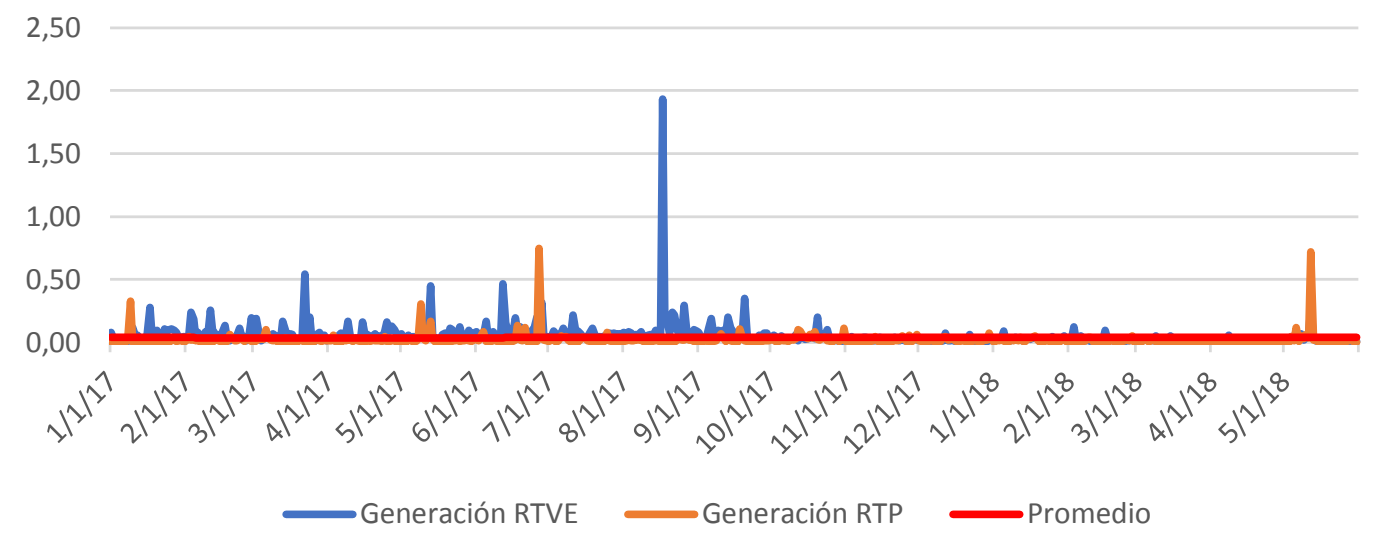

Fuente: Elaboración propia

En el caso de Portugal los hechos vuelven a focalizarse en dos eventos musicales. El que tiene una mayor repercusión en cuanto a comentarios es el concierto solidario "Juntos por todos" celebrado el día 27/06/201 en Lisboa con motivo de los incendios que días antes se habían producido en el país luso y el 12/05/2018 que se relaciona nuevamente con el festival de Eurovisión.

Para finalizar se presenta el parámetro sugerencia cuyo promedio para las páginas de RTVE y RTP se sitúa en 0,03.

En esta ocasión, parece evidente que exista una relación con la variable generación puesto que el motivo que lleva a un usuario a realizar un comentario, podría ser el mismo que le incite a compartir el contenido con su red social digital. Este hecho se muestra el 17/08/2017 en RTVE, resultado de los atentados de Barcelona donde se llegan a realizar más de 31.900 comparticiones a lo largo del día. 
Figura 4. Sugerencia de las páginas de Facebook de RTVE y RTP

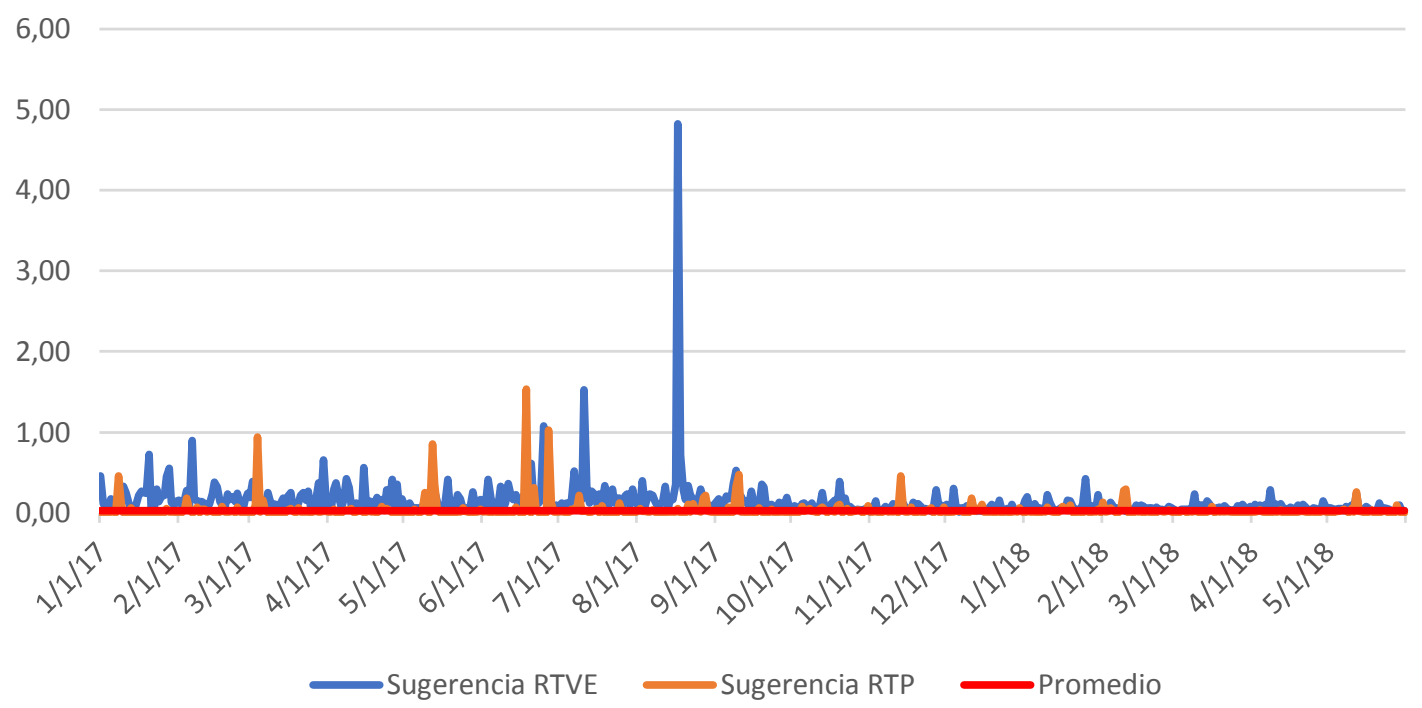

Fuente: Elaboración propia

Sin embargo, en la Figura 4 sobresalen otros datos que pasaban desapercibidos en el gráfico anterior. El 11/07/2017 se registra una tasa de 1,52 por parte de RTVE debido a la compartición de una publicación sobre el encierro de los San Fermines. Por su parte RTP alcanzaba una tasa de 1,53 de sugerencia el 18/06/2018, al coincidir con la noticia de los 57 muertos en el incendio de Pedrógão Grande. A este hecho le sucede la gala solidaria del 27/06/2017 que obtiene una tasa del 1,3. Por último, cabe destacar también el día 12/05/2017 debido a la ceremonia religiosa de Fátima y el 04/03/2017 consecuencia del encuentro entre Madeira Rodrigues y Jorge Jesús en las elecciones del Sporting.

A colación de lo anterior se evidencia la importancia que Facebook representa para las radiotelevisiones públicas de España y Portugal como plataforma de difusión, información y promoción de acontecimientos sociales.

\section{Referencias bibliográficas}

Campos Freire, F. (2013). El futuro de la TV europea es híbrido, convergente y cada vez menos público". Revista Latina de Comunicación Social, 68, 89-118. 
Campos Freire, F. (2016). Situación actual y tendencias de la radiotelevisión pública en Europa. Santiago de Compostela: Universidad de Santiago de Compostela / FORTA.

Fernández Lombao, T. y Valencia Bermúdez, A. (2015). La gestión de las redes sociales en los servicios de radiodifusión públicos europeos. En Campos, F. y Rúas, J. (eds.), Las redes sociales digitales en el ecosistema mediático (254-272). Cuadernos Artesanos de Comunicación 92: La Laguna, Tenerife.

Giraldo, C. y Martínez, S. (2015). Análisis de la actividad y presencia en redes sociales de las principales cadenas hoteleras y de los portales turísticos de las comunidades autónomas españolas. Trabajo fin de Máster: Universidad Politécnica de Cartagena.

Giraldo, C. y Martínez, S. (2017). Análisis de la actividad y presencia en Facebook y otras redes sociales de los portales turísticos de las comunidades autónomas españolas. Cuadernos de turismo, 39, 239-264.

Giraldo, C. y Sánchez, N. (2014). Análisis de la actividad en redes sociales de marcas del sector moda: una aproximación al social commerce. Trabajo fin de Grado: Universidad Politécnica de Cartagena.

Hidalgo-Marí, T. y Segarra-Saavedra, J. (2017). La presencia de la televisión pública española en redes sociales. Estudio de caso de las televisiones nacionales y autonómicas en los social media. En Castelló-Martínez, A., del Pino-Romero, C. (eds.), Publicidad y Convergencia Mediática. Nuevas estrategias de comunicación persuasiva (28-41). Egregius: Sevilla.

IAB Spain (2012). I Estudio Actividad de las marcas en medios sociales. Recuperado el 15 de junio de 2018, de https://goo.gl/cmXTci

IAB Spain (2016). IV Estudio Actividad de las marcas en medios sociales. Recuperado el 13 de junio de 2018, de https://goo.gl/byWhce

Internet República (2012). Estudio la Banca a Examen en las Redes Sociales. Recuperado el 15 de junio de 2018, de http://www.slideshare.net/slideshow/embed code/11256128 
Rodríguez, M.M., Rodríguez, C, Viñán, C, Martínez, V.A. (2016). Competing tourist destinations and their positioning on the social medium Facebook. Ecuador, Colombia and Perú. Advances in Intelligent Systems and Computing, 445, 449-459.

Sánchez, E., Ludeña, A., Viñán C., y Martínez, V.A. (2015). Impacto en los Medios Sociales del turismo religioso en la región andina ecuatoriana: El caso de la peregrinación de la Virgen de El Cisne y la Feria Comercial de Loja. I XESCOM, Simposio Internacional sobre Gestión de la Comunicación, Pontevedra.

Statista (2018). Ranking de las principales redes sociales a nivel mundial según el número de usuarios activos en abril de 2018 (en millones). Recuperado el 15 de junio de 2018, de https://es.statista.com/estadisticas/600712/ranking-mundialde-redes-sociales-por-numero-de-usuarios $/$

\section{Reconocimientos de la investigación}

Los resultados de este trabajo corresponden al proyecto de "Indicadores de gobernanza, financiación, rendición de cuentas, innovación, calidad y servicio público de las RTV europeas aplicables a España en el contexto digital" (Referencia CSO2015-66543-P) del Programa estatal de Fomento de la Investigación Científica y Técnica de Excelencia, subprograma estatal de Generación de Conocimiento del Ministerio de Economía y Competitividad de España, cofinanciado por el Fondo Europeo de Desarrollo Regional (FEDER) de la Unión Europea. Así como de la actividad de la Red Internacional de Investigación de Gestión de la Comunicación (REDES 2016 G-1641 XESCOM) apoyada por la Consellería de Cultura, Educación e Ordenación Universitaria de la Xunta de Galicia (referencia ED341D R2016/019). 



\title{
Modelos y tendencias de la radiotelevisión pública regional europea
}

\author{
Marta Rodríguez-Castro \\ Universidade de Santiago de Compostela \\ Mónica López-Golán \\ Pontificia Universidad Católica del Ecuador, Sede Ibarra
}

\begin{abstract}
PARA CITAR: Rodríguez-Castro, M. y López-Golán, M. (2018). Modelos y tendencias de la radiotelevisión pública regional europea. En Pérez-Seijo, S., Rodríguez-Castro, M. y Túñez-López, M. (Eds.), Debates sobre valores e indicadores del servicio audiovisual público en Europa (pp. 157-172). Cuadernos Artesanos de Comunicación, cac142. La Laguna (Tenerife): Latina. DOI: 10.4185/cac142
\end{abstract}

\section{Resumen}

Las radiotelevisiones regionales públicas han experimentado fuertes transformaciones durante los últimos años debido a los cambios en el mercado audiovisual, marcado por la transnacionalización y la concentración mediática, que han obligado a este tipo de medios a reivindicar su valor como espacios identitarios de proximidad. En este capítulo se abordan, en primer lugar, las principales modalidades de televisión pública regional presentes en el marco de la Unión Europea, para después analizar tres tendencias dentro de esta modalidad de comunicación de proximidad: una leve pero relevante descentralización en el Reino Unido, su pérdida de autonomía en los Países Bajos, y un resurgir en la Comunidad Valenciana (España). Se concluye que la protección y el fomento de unos medios de comunicación públicos regionales debe contar con un compromiso 
político que legitime y revalorice su función como espacios de comunicación de proximidad.

Palabras clave: televisión regional, televisión pública, estudio comparativo, medios de proximidad, gobernanza.

\section{La importancia de los medios públicos de proximidad}

Los medios de comunicación públicos llevan años experimentando un proceso de transformación que les permita adaptarse a un contexto mediático volátil, en constante cambio, en el que grandes plataformas digitales y grupos mediáticos transnacionales ganan poder en los mercados de todo el mundo (Moore y Tambini, 2018). La nueva ecología mediática, caracterizada por la transnacionalización de la producción de contenidos cada vez más personalizados y a los que la audiencia puede acceder desde múltiples dispositivos en el lugar y el momento que prefiera, ha supuesto todo un reto para los medios de comunicación públicos, que necesitan buscar nuevas estrategias (ampliación de canales y/o plataformas, colaboración entre distintas organizaciones) que les permita adaptarse al nuevo orden mediático (Chalaby, 2010) y poder seguir jugando un papel clave en la vertebración de los respectivos mercados nacionales y/o regionales.

Los medios públicos de proximidad también se han visto afectados por cambios similares a los de sus homólogos nacionales, especialmente los relacionados con cuestiones de gobernanza, financiación y misión de servicio público, y a pesar de que estas reformas no siempre suponen un refuerzo del sistema de medios regionales (Azurmendi, 2013), la comunicación de proximidad es hoy, en un contexto transnacional marcado por la concentración mediática, de vital relevancia para la conexión y la cohesión de las comunidades e identidades regionales y locales. Tal y como afirman Manias-Muñoz y Muntsant (2017: 192), "en un contexto de globalización, los mecanismos comunicativos que permiten fortalecer las identidades más próximas al individuo adquieren una importancia destacada". De no ser por este tipo de medios de comunicación, las identidades minoritarias quedarían marginadas del espacio mediático, tan importante para la construcción de la identidad cultural y el cuestionamiento de los significados (Barker, 2003). 
El complemento "de proximidad" fue elegido por permitir condensar la esencia de este tipo de medios de comunicación, englobando "la polisemia de lo local con las nociones de territorio, identidad, pero también la complicidad entre emisores y audiencias y, muy importante, [en el caso de España] como marco competencial para el nuevo sistema audiovisual democrático" (de Moragas, 2015: 25).

A pesar de que la comunicación de proximidad comprende medios de comunicación, tanto públicos como privados, dirigidos a comunidades de distintos tamaños y características, en este capítulo nos centraremos en una de sus principales tipologías: las radiotelevisiones públicas vinculadas a las regiones en Europa. En primer lugar, se delimitará el concepto de televisión regional, para después describir las distintas articulaciones que este concepto presenta en los Estados Miembros de la Unión Europea. En la segunda parte del capítulo se describen tres tendencias de la radiotelevisión regional europea a través de los casos del Reino Unido, los Países Bajos y la Comunidad Valenciana (España).

\section{2. ¿De qué hablamos cuando hablamos de radiotelevisión regional?}

La organización del territorio dentro de los distintos países de la Unión Europea es diversa y de difícil homologación, por lo que la definición de "televisión regional" resulta igualmente compleja. El concepto de televisión regional puede hacer referencia a medios de comunicación dirigidos a comunidades de distinto tamaño y características identitarias, en función de cada contexto nacional, por lo que trazar una panorámica que comprenda toda esta diversidad constituye una tarea de gran dificultad (OAE, 2016).

Uno de los factores que más ayudan a la hora de delimitar el concepto de región (y, por extensión, de radiotelevisión regional) es la presencia de una lengua propia, tal y como argumentan Sampedro Blanco y Van den Bulck (1995: 248) al definir una región como "una cultura diferenciada dentro de un estado-nación separada del resto del estado por una lengua común". Sin embargo, y a pesar de que el factor idiomático juega un papel fundamental en la delimitación de regiones en países como Bélgica, este rasgo identitario no es el único delineante de las regiones. 
Independientemente de la diversidad de formas que adopte el concepto "región" en Europa, la presencia de medios de comunicación, tanto públicos como privados, en estos espacios es una característica muy extendida, especialmente a partir del proceso de regionalización que tuvo lugar en las décadas de los 70 y los 80 del siglo pasado (Garitaonandía, 1993). Sin embargo, esta presencia de medios regionales es especialmente relevante en aquellos contextos en los que las regiones han tomado conciencia política y cultural con respecto a su diferenciación del resto del Estado del que forman parte (Sampedro Blanco y Van den Bulck, 1995: 249). Al reconocer el poder de los medios de comunicación como espacios de formación y representación de las identidades, en estas comunidades con conciencia de diferenciación las demandas de mayores competencias han abarcado también el desarrollo de una radiotelevisión pública regional.

Este tipo de factores contextuales han moldeado las distintas formas que presenta la televisión regional pública en Europa, con distintos niveles de autonomía tanto en su organización como en su misión de servicio público y los tipos de contenidos que ofertan.

\subsection{Articulaciones de la televisión pública regional en Europa}

Tabla 1. Modelos de televisión pública regional en función de su autonomía

\begin{tabular}{|c|c|}
\hline- & $\begin{array}{l}\text { 1. Centros de producción regional que trabajan para una televisión } \\
\text { nacional como corresponsales informativos. Ej. Irlanda. }\end{array}$ \\
\hline \multirow{3}{*}{ 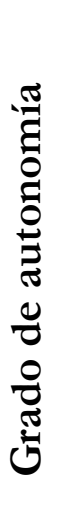 } & $\begin{array}{l}\text { 2. Centros de producción regional que tienen derechos exclusivos } \\
\text { para emitir información regional en su región. Ej. Francia, Italia. }\end{array}$ \\
\hline & $\begin{array}{l}\text { 3. Centros de producción regional que disponen de más de una hora } \\
\text { de emisión y cuya misión de servicio público no está limitada a la } \\
\text { información, sino que comprende también programas de cultura y } \\
\text { entretenimiento. Dependen de una emisora nacional. Ej. Reino } \\
\text { Unido (BBC) }\end{array}$ \\
\hline & $\begin{array}{l}\text { 4. Centros de producción regional con una programación completa, } \\
\text { pero que se encuentran dentro del marco de una organización que } \\
\text { cubre un territorio más amplio. Ej. Alemania (ARD). }\end{array}$ \\
\hline+ & $\begin{array}{l}\text { 5. Radiotelevisiones regionales totalmente independientes. Ej. } \\
\text { España, Bélgica }\end{array}$ \\
\hline
\end{tabular}

Fuente: Zimmerman (1990)

La comunicación de proximidad de la que disfrutan las regiones dentro del marco europeo presenta una gran diversidad de articulaciones. A pesar de que, como se apuntó antes, su diversidad dificulta su 
categorización, han sido varios los intentos de establecer modelos de televisión regional pública.

A pesar de que las categorías establecidas por Zimmerman resultan de utilidad a la hora de determinar la autonomía de las regiones en relación al tipo de contenidos que pueden producir y de su relación con medios de ámbito nacional, para este estudio consideramos más pertinente la categorización diseñada por el Observatorio Audiovisual Europeo (OAE) en un informe de 2016. El modelo del OAE traza unas categorías más amplias y mejor definidas, contempla las especificidades de las regiones y/o comunidades que cuentan con lengua propia (especialmente las minoritarias) y también recoge las relaciones entre esta comunicación de proximidad y los medios de comunicación nacionales.

Tabla 2. Modelos de televisión regional pública presentes en la Unión Europea

\begin{tabular}{|c|c|c|c|c|c|}
\hline $\begin{array}{c}\text { Televisiones } \\
\text { regionales } \\
\text { autónomas }\end{array}$ & $\begin{array}{c}\text { Canales } \\
\text { lenguas } \\
\text { minoritarias }\end{array}$ & $\begin{array}{c}\text { Canales } \\
\text { de TV } \\
\text { regionales }\end{array}$ & $\begin{array}{c}\text { Estudios } \\
\text { regionales/ } \\
\text { Ventanas }\end{array}$ & $\begin{array}{l}\text { Centros de } \\
\text { producción } \\
\text { regionales }\end{array}$ & $\begin{array}{c}\text { Sin } \\
\text { televisión } \\
\text { regional }\end{array}$ \\
\hline $\begin{array}{l}\text { Bélgica } \\
\text { Alemania } \\
\text { España }\end{array}$ & $\begin{array}{l}\text { Finlandia } \\
\text { Reino Unido } \\
\text { Irlanda } \\
\text { Rumanía } \\
\text { Eslovenia }\end{array}$ & $\begin{array}{l}\text { Francia } \\
\text { Grecia } \\
\text { Países } \\
\text { Bajos } \\
\text { Portugal } \\
\text { Reino } \\
\text { Unido } \\
\text { Eslovenia }\end{array}$ & $\begin{array}{l}\text { Austria } \\
\text { Bulgaria } \\
\text { Rep. Checa } \\
\text { Alemania } \\
\text { Dinamarca } \\
\text { España } \\
\text { Finlandia } \\
\text { Francia } \\
\text { Reino Unido } \\
\text { Italia } \\
\text { Polonia } \\
\text { Rumanía } \\
\text { Suecia }\end{array}$ & $\begin{array}{l}\text { Grecia } \\
\text { Croacia } \\
\text { Hungría } \\
\text { Irlanda } \\
\text { Eslovaquia }\end{array}$ & $\begin{array}{l}\text { Chipre } \\
\text { Estonia } \\
\text { Letonia } \\
\text { Lituania } \\
\text { Luxemburgo } \\
\text { Malta }\end{array}$ \\
\hline
\end{tabular}

Fuente: adaptado a partir de la información de OAE (2016).

En la tabla 2 se clasifican los 28 Estados Miembros de la Unión Europea en función de la articulación de su sistema audiovisual público regional. Como se puede apreciar en la última columna, un total de seis países comunitarios no cuentan con radiotelevisión pública regional, aunque todos ellos constituyen Estados de pequeño tamaño que no hace tan necesaria este tipo de comunicación de proximidad como en Estados más amplios. En otros casos, como el español, pueden darse dos o más articulaciones de la televisión pública regional, como se desarrollará a continuación. 
La categoría de televisión pública regional con un mayor grado de autonomía la comparten tanto la clasificación de Zimmerman como la del OAE. Bélgica, España y Alemania se encuentran bajo esta etiqueta, aunque presentan fuertes diferencias entre ellos. En Bélgica, por ejemplo, existen tres televisiones públicas regionales, una para cada una de las comunidades lingüísticas del país (la RTBF en la Comunidad francesa, la VRT en la flamenca y la BRF en la minoritaria comunidad germanoparlante). Cada una de ellas cuenta con total independencia con respecto a sus homólogas y no existe ninguna radiotelevisión pública común para el conjunto del territorio belga. A pesar de que el sistema belga podría incluirse tanto en la primera como en la segunda categoría, porque la organización de las comunidades lingüísticas obedece principalmente a una cuestión de idioma ${ }^{12}$, hemos considerado la inclusión de Bélgica en la categoría de televisiones regionales autónomas porque son independientes entre sí.

En Alemania, donde la radiotelevisión también es competencia de las regiones (los Länder), la colaboración es fundamental. Las nueve radiotelevisiones públicas alemanas (algunas, como la BR, dirigidas a una sola región, y otras, como la MDR, que engloban a varias) se encuentran asociadas en la ARD desde 1945. A través del canal televisivo Das Erste, las radiotelevisiones públicas configuran una programación que plasma la diversidad regional alemana. Además, en 1961 los Länder volvieron a aunar fuerzas para crear la ZDF (Zweite Deutsche Fernsehen), también de alcance nacional.

Una situación diferente se da en España, donde existen dos tipos de radiotelevisiones públicas totalmente independientes. Por una parte, la Corporación de Radio y Televisión Española cuenta con centros de producción regional que actúan como corresponsalías para los servicios informativos nacionales, pero que también cuentan con

${ }^{12}$ La marcada estructura regional del sistema audiovisual público belga se debe a dos motivos correlacionados. Por una parte, la existencia de varios idiomas en distintos territorios del Estado ha favorecido la creación de mercados audiovisuales diferentes. Por otra parte, el proceso de toma de conciencia política y cultural de las regiones ha sido clave en el proceso de regionalización de la televisión pública belga que, en sus orígenes, se trataba de una competencia nacional (Sampedro Blanco \& Van den Bulck, 1995). 
espacios de producción propia que se emiten en los canales de TVE a través de desconexiones. A esta primera articulación regional, en la que se hará hincapié más adelante, hay que sumar la existencia de televisiones regionales en trece de las diecisiete Comunidades Autónomas del país. Cada una de estas corporaciones públicas es independiente, se rige por leyes autonómicas y emite para su región, fomentando, en el caso de que la Comunidad Autónoma cuente otra lengua oficial además del castellano, la lengua autóctona.

Otra articulación diferente de la televisión pública regional, con un grado de autonomía menor, consiste en la existencia de canales regionales dentro de una corporación nacional. En este caso, se podrían distinguir dos subcategorías: canales que ofrecen contenidos específicos para regiones concretas, dentro del territorio nacional o en ultramar; y canales dirigidos a lenguas minoritarias.

Los canales específicos para territorios en ultramar se dan en televisiones de corte centralista como la francesa, con nueve canales regionales de este tipo, o la portuguesa, con dos. El Reino Unido ${ }^{13}$, con una televisión pública nacional que ha sido objeto de críticas por su visión centralista (Goldsmiths, 2016) también ha experimentado un proceso de descentralización de la BBC a partir de la devolución de competencias a las distintas naciones. La situación contraria ha sucedido en los Países Bajos, donde las radiotelevisiones públicas regionales han visto reducida su autonomía a raíz de la última revisión de la Ley de Medios en 2016. En estas dos tendencias ahondaremos en el siguiente apartado de este capítulo.

Dentro de los canales regionales de radiotelevisiones nacionales se encuentran también las dirigidas a lenguas o comunidades minoritarias. Este sería el caso de Finlandia, donde la YLE cuenta con un canal en sueco; de Irlanda, con un canal en gaélico irlandés, o Eslovenia, con un

${ }^{13} \mathrm{El}$ sistema británico de radiotelevisión pública presenta la particularidad de que, además de contar con una corporación pública, la BBC, esta coexiste con otras televisiones comerciales con actividades de servicio público asignadas. En este estudio tan solo se ha considerado la articulación regional de la BBC, pero en futuras investigaciones se abordará el sistema audiovisual público regional británico en toda su complejidad. 
canal con programación en húngaro. También en el Reino Unido, los hablantes de gaélico escocés pueden acceder a programación en su idioma a través de BBC Alba. Un caso especial es el de Rumanía, que dedica su tercer canal a las regiones a través de cinco ventanas de desconexión con programación en tres idiomas minoritarios diferentes (húngaro, serbio y alemán).

Este tipo de desconexiones territoriales constituyen otra modalidad de televisión regional, aunque con una autonomía muy limitada. Aun así, con trece países haciendo uso de estas ventanas, se trata de la forma más extendida en Europa para ofrecer contenido de proximidad a las regiones. En Austria, la ORF cuenta con nueve centros territoriales, uno en cada provincia, en los que se producen los respectivos informativos de corte territorial, emitidos de forma simultánea a través de ventanas de desconexión en el segundo canal de la corporación pública, ORF2. Algo similar sucede con la televisión danesa TV 2, a medio camino entre lo comercial y lo privado, que cuenta con ocho centros regionales encargados de producir informativos regionales para emitir en las desconexiones territoriales del canal principal de TV 2.

El último escalafón dentro de las articulaciones de la televisión regional en Europa son los centros de producción regionales dentro de una televisión pública de alcance nacional, actuando como corresponsalías en las que se produce contenido (mayoritariamente informativo) vinculado a las regiones que después se distribuye a todo el país. El número de centros regionales de los que dispone cada radiotelevisión pública, que varía enormemente en función de cada país, permite intuir el grado de centralismo que se refleja en su programación. Por ejemplo, mientras que Croacia cuenta con hasta 20 estudios regionales, Irlanda tiene ocho, y Hungría dispone tan sólo de dos. La televisión pública magiar anunció en 2015 su intención de crear un nuevo canal televisivo (M6) destinado a las regiones, pero la Autoridad Nacional de Medios (NMHH) prohibió en 2016 el lanzamiento de más canales.

\section{Tendencias de la televisión regional europea.}

El contexto que ha sido descrito en las páginas anteriores no ha estado exento de cambios y transformaciones, impulsadas por motivaciones diversas, que en algunos países han remodelado la televisión pública regional de forma relevante. A continuación, se realizará una 
aproximación a tres casos concretos en los que los medios públicos regionales han experimentado, respectivamente, una mejor de su autonomía, un detrimento de su independencia, y un resurgimiento tras la crisis.

\subsection{La descentralización reticente de la BBC}

El sistema audiovisual público británico, además de por su prestigio y reconocimiento internacional, también se ha caracterizado tradicionalmente por un fuerte centralismo. El proceso de descentralización o devolución de competencias a las naciones del Reino Unido iniciado en la década de 1990 supuso una fuerte transformación en muchos ámbitos, pero no en la radiotelevisión, que permaneció bajo el control de los sucesivos gobiernos de Westminster (Hibberd, 2007). A pesar de la existencia de centros regionales de la $\mathrm{BBC}$ en Escocia, Gales e Irlanda del Norte, la corporación pública gestionaba su actividad desde Londres.

Ante esta situación, a principios del siglo XXI se empezó a gestar en Escocia una demanda de cesión de control a las naciones en esta materia, situando a la BBC en el punto de mira. Con la llegada del Scottish National Party (SNP) al gobierno escocés, estas demandas se intensificaron. Una de las principales exigencias procedentes de Escocia fue el denominado "Scottish Six", es decir, una desconexión de la emisión general de BBC1 durante la emisión del boletín informativo más popular en términos de audiencia en el Reino Unido, entre las 18:00 y las 19:00, para poder emitir en esta franja horaria un informativo producido desde BBC Scotland bajo una visión de proximidad, con contenidos de más interés para las audiencias escocesas.

Sin embargo, estas demandas no fueron bien recibidas en Londres, ni por parte del gobierno ni por la BBC. John Birt, antiguo director general de la corporación, recogió en sus memorias que la introducción del "Scottish Six" conduciría a un BBC federal y débil. Por otra parte, también se temía que ceder competencias en esta materia pudiese alimentar el sentimiento independentista que empezaba entonces a cobrar gran fuerza (Schlesinger, 2008).

Las posiciones de la BBC y del gobierno central tuvieron que flexibilizarse un poco tras la celebración del referéndum por la 
independencia de Escocia. A pesar de que la permanencia en el Reino Unido fue la elegida por la mayoría de los votantes, el problema escocés no podía continuar siendo ignorado. Ambas partes se sentaron a negociar una nueva distribución de competencias, entre las que se encontraba el Gaelic Media Service. El hecho de que esta negociación coincidiese con el proceso de renovación de la Royal Charter, el texto legal que define la misión y la actividad de la BBC, aceleró la introducción de cambios en la $\mathrm{BBC}$ con respecto a su relación con las naciones, en un intento también de mejorar su representación de las naciones y regiones británicas, tarea en la que la BBC no estaba obteniendo un buen desempeño (ICM, 2016)

Así, la nueva Royal Charter (2016), que estará vigente hasta finales de 2027, vuelve a incluir entre los propósitos públicos de la corporación la representación de las naciones, regiones y comunidades británicas. Además, la gobernanza y la redición de cuentas ya no se limitan a los organismos centrales, sino que se extienden a las instituciones descentralizadas en Escocia, Irlanda del Norte y Gales. En el ámbito de la gobernanza, cada una de las cuatro naciones cuenta con un representante en el BBC Board, el nuevo órgano de dirección de la corporación, de forma similar a lo que anteriormente sucedía con el ya extinguido BBC Trust.

En relación a la rendición de cuentas, el nuevo marco legal de la BBC exige que los planes de la corporación contemplen su actividad en las naciones y regiones británicas. Además, los informes anuales deben, por una parte, recoger el desempeño y el impacto de este propósito público de la $\mathrm{BBC}$ en los distintos territorios $\mathrm{y}$, por otra, ser entregados a los ministros escoceses, galeses y norirlandeses de forma simultánea al depósito de los mismos en el Parlamento Británico y la Ofcom. La BBC está obligada a comparecer ante los parlamentos o asambleas de las naciones descentralizadas si así lo requieren.

Los cambios en la nueva Royal Charter supusieron toda una declaración de intenciones dentro de la relación entre la BBC y las naciones, pero el gran avance en el reconocimiento de la necesidad de atender a las naciones por parte de la corporación se dio en 2017, cuando la televisión pública británica anunció importantes inversiones en Irlanda del Norte (11 millones de libras), Gales (8,5 millones de libras) y Escocia, la nación que recibió el incremento presupuestario más 
elevado, con 20 millones de libras. Además, estas inversiones también fueron acompañas del anuncio de la intención de la BBC de crear un canal de televisión propio para BBC Scotland. El lanzamiento de este canal está previsto para otoño de 2018, pero en el momento de la redacción de este capítulo (junio de 2018) la Ofcom todavía se encontraba tramitando el Public Interest Test mediante el cual, si el valor público de la propuesta justifica su impacto de mercado, se aprobará oficialmente el canal.

A pesar de la importancia de estos avances, ni BBC Scotland ni ningún otro centro regional tiene todavía la capacidad de servir a sus respectivas comunidades de la misma forma que lo hacen sus homólogas, belgas, alemanas o españolas. Está todavía por determinar si los cambios producidos en los últimos años, junto con los servicios regionales de otras televisiones públicas con misión de servicio público, como ITV, conseguirán satisfacer las necesidades de las regiones en cuestiones comunicativas.

\subsection{La centralización de la televisión regional neerlandesa}

En los Países Bajos, la radiotelevisión pública regional ha experimentado el proceso inverso al que se acaba de describir. Hasta 2016, en los Países Bajos existían trece televisiones públicas regionales, financiadas con fondos públicos e independientes entre ellas. A partir de la modificación de la Ley de Medios en 2016, todas ellas han pasado a depender del RPO (Regionale Publieke Omroep, Televisión Pública Regional).

Tras las elecciones generales de 2012, el gobierno de coalición conformado por el Partido Popular por la Libertad y la Democracia y por el Partido del Trabajo emprendió una reforma radical del sistema audiovisual público, tanto nacional como regional, que se caracterizó por los recortes presupuestarios y la fusión de medios de comunicación que hasta el momento gozaban de cierta independencia.

Así, antes de 2012 existían trece televisiones regionales autónomas, una por cada región neerlandesa (excepto por la región de Holanda Meridional, que contaba con dos). Cada televisión regional era independiente, aunque todas se encontraban asociadas en la Fundación ROOS (Sichting ROOS), a través de la que participan en el proceso de 
político y que actuaba en representación de las televisiones públicas regionales en negociaciones como las de carácter laboral (OAE, 2016).

Sin embargo, las reformas de la Ley de Medios llevadas a cabo en 2016 por parte del gobierno de coalición, motivadas por una voluntad de transferir la responsabilidad financiera y administrativa de las radiotelevisiones regionales al gobierno central, supusieron un fuerte recorte tanto en medios económicos como en cuestiones de autonomía. Desde entonces, las televisiones regionales vieron reducido su presupuesto en más de 17 millones de euros, y su asociación en la Fundación ROOS fue sustituida por la pertenencia a la RPO.

La misión de la RPO es fortalecer la oferta informativa y el patrimonio cultural de las emisoras regionales (Mediawet, 2008: 2.60). Sus competencias van más allá de las de su antecesor, ya que, además de intentar promover la colaboración entre las distintas televisiones públicas regionales, también controla su financiación y su supervisión. Al tratarse de una modificación muy reciente, todavía es difícil determinar el impacto real en la oferta de una comunicación de proximidad para las regiones neerlandesas, aunque la pérdida de autonomía de las televisiones regionales, junto con los recortes presupuestarios, parecen indicar a una pauperización del sistema audiovisual público de los Países Bajos.

\subsection{El resurgir de la radiotelevisión pública valenciana}

El 29 de noviembre de 2013, la Radiotelevisió Valenciana (RTVV), después de 24 años de servicio ininterrumpido a los ciudadanos de la Comunidad Valenciana, cesó su emisión. Tras el argumento oficial, de corte económico, que justificaba el cierre de la televisión autonómica ante la imposibilidad de asumir la reincorporación de los trabajadores despedidos mediante un expediente de regulación de empleo que había sido declarado ilegal, se encontraba otro de carácter político (Marzal Felici, Izquierdo Castillo y Casero Ripollés, 2015). La desconexión entre RTVV y su público, debido en gran parte a las interferencias del poder político en la dirección del medio público y a su alto grado de privatización, también contribuyó a su desaparición.

En junio de 2018, cuatro años y medio después de la desaparición de RTVV, iniciaba sus emisiones continuas À Punt, la nueva radiotelevisión pública valenciana. À Punt arranca tras el cambio a un 
gobierno de coalición de izquierdas en la Generalitat Valenciana, con un presupuesto más limitado que su antecesora y con procesos de gobernanza más transparentes, pensados para garantizar una televisión pública independiente (Beltran, 2018). Lo hace, además, con una redacción común para todos los servicios del medio público (radio, televisión y web), aspirando así a una comunicación más integrada. Está todavía por ver la acogida que tendrá este nuevo medio público entre los ciudadanos valencianos.

\section{La voluntad política como salvaguarda de las televisiones públicas regionales}

La descripción de la situación global de la televisión pública regional en Europa, así como los tres casos que se han perfilado, ilustran la volatilidad de este tipo de sistemas de comunicación de proximidad. Los cambios en el entorno mediático (por la creciente competencia de otros medios transnacionales que atraen el interés de las audiencias) y en el político (por la expansión de la tendencia neoliberalista a favorecer los servicios privados en detrimento de los públicos) sitúan a las televisiones regionales ante el reto de mantener su legitimidad para continuar sirviendo a sus comunidades.

La situación del Reino Unido, donde la tradicionalmente centralista $\mathrm{BBC}$ parece empezar a replantearse su relación con las naciones, choca con el proceso de centralización de la televisión regional neerlandesa, víctima de los recortes neoliberales. El resurgimiento de la televisión pública valenciana contribuye al reconocimiento del valor de los medios de proximidad en un contexto en el que el resto de las televisiones autonómicas españolas deben hacer grandes esfuerzos para frenar el descenso en sus audiencias, en sus presupuestos y en su legitimidad.

Ante esta situación, se requiere de un compromiso político claro que permita proteger, tanto mediante el desarrollo de políticas a nivel regional, nacional y europeo como a través de una financiación sólida y estable, la existencia de un sistema audiovisual público regional fuerte, de valor y al servicio de los ciudadanos. 


\section{Bibliografía}

Azurmendi, A. (2013). Reformas de la televisión regional europea con lengua propia en el contexto actual de crisis. Revista Latina de Comunicación Social, 68, 355 - 382. DOI:

https://doi.org/10.4185/RLCS-2013-981.

Barker, Ch. (2003). Televisión, globalización e identidades culturales. Barcelona: Paidós.

Chalaby, J. K. (2010). Public Broadcasters and Transnational Television: Coming to Terms with the New Media Order. En Iosifidis, P. (ed.), Reinventing Public Service Communication. European Broadcasters and Beyond (101-113). Basingstoke, United Kingdom: Palgrave Macmillan.

de Moragas, M. (2015). La comunicación de proximidad 30 años después. En A. Nerekan Umaran, M.A. Casado del Río, R. Zallo Elgezabal y J.C. Miguel de Bustos (Eds.), Comunicación de proximidad. Cada vez más lejos. Marco, experiencias y regulación (2137). Bilbao: Universidad del País Vasco.

Garitaonandía, C. (1993). Regional Television in Europe. European Journal of Communication, 8, 277-294.

Hibberd, L. (2007). Devolution in Policy and Practice: A Study of River City and BBC Scotland. Westminster Papers in Communication and Culture 4(3), 107-125.

Manias-Muñoz, M. y Muntsant, A. M. (2017). BBC Alba: Servicio público y representación gaélica en Escocia. Historia y Comunicación Social, 22(1), 191-206.

Marzal Felici, J., Izquierdo Castillo, J. y Casero Ripollés, A. (2015). La crisis de la televisión pública y el cierre de RTVV como síntoma. En Marzal Felici, J., Izquierdo Castillo, J. y Casero Ripollés, A. (eds.), La crisis de la televisión pública. El caso de RTVV y los retos de la nueva gobernanza (11-19). Bellaterra: Universitat Autonoma de Barcelona. Servei de Publicacions.

Moore, M. y Tambini, D. (2018). Digital Dominance. The power of Google, Amazon, Facebook and Apple. Oxford: Oxford University Press. 
Sampedro Blanco, V., y Van den Bulck, J. (1995). Regions vs states and cultures in the EC media policy debate: regional broadcasting in Belgium and Spain. Media, Culture \& Society, 17, 239-251.

Schlesinger, P. (2008). Broadcasting Policy and the Scottish Question. En Gardham, T. y Levy, D.A.L. (Eds.), The Price of Plurality:

Choice, Diversity and Broadcasting Institutions in the Digital Age (155161). Oxford: Reuters Institute for the Study of Journalism.

Zimmerman, P. (1990). Las televisiones regionales en Europa. En RTVV (ed.), Las radiotelevisiones en el espacio europeo (130-148). Valencia: RTVV.

\subsection{Otros documentos}

Beltrán, A. (2018, 9 de junio). Arranca À Punt: la nueva televisión valenciana es cuatro veces más barata que Canal 9. Eldiario.es. Recuperado el 11 de junio de 2018, de https://goo.gl/a81Hjv.

Department for Culture, Media and Sport (2006). Royal Charter for the continuance of the British Broadcasting Corporation. Recuperado el 8 de junio de 2018, de https://goo.gl/YvvChh. Goldsmiths (2016). A future for Public Service Television. Content and Platforms in a digital world. Londres: University of London.

ICM Unlimited (2016). Purpuse Remit Survey Autumn 2016. UK Report.

Mediawet, (2008). Wet van 29 december 2008 tot vaststelling van een nieuwe Mediawet. Recuperado el 8 de junio de 2018, de https://goo.gl/7GmHc3.

Observatorio Audiovisual Europeo (2016). Regional and local broadcasting in Europe. Estrasburgo: Observatorio Audiovisual Europeo. 


\section{Reconocimientos de la investigación}

- Los resultados de este artículo corresponden al proyecto de "Indicadores de gobernanza, financiación, rendición de cuentas, innovación, calidad y servicio público de las RTV europeas aplicables a España en el contexto digital" (Referencia CSO2015-66543-P) del Programa estatal de Fomento de la Investigación Científica y Técnica de Excelencia, subprograma estatal de Generación de Conocimiento del Ministerio de Economía y Competitividad de España, cofinanciado por el Fondo Europeo de Desarrollo Regional (FEDER) de la Unión Europea. Así como de la actividad de la Red Internacional de Investigación de Gestión de la Comunicación (REDES 2016 G-1641 XESCOM) apoyada por la Consellería de Cultura, Educación e Ordenación Universitaria de la Xunta de Galicia (referencia ED341D R2016/019). La autora Marta Rodríguez Castro es beneficiaria del Programa de Formación del Profesorado Universitario (FPU16/05234) financiado por el Ministerio de Educación, Cultura y Deporte (Gobierno de España). 


\section{Las autoras y los autores}

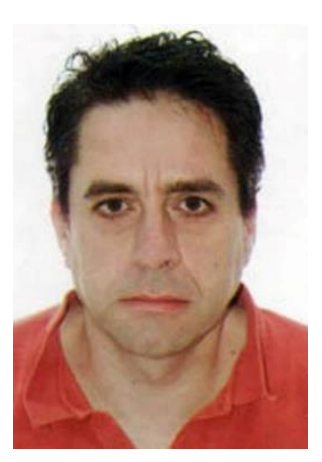

\section{ALÉN-AMIL, JOSÉ ÁNGEL}

\section{Universidad de Vigo}

alenamil@gmail.com

Graduado en Comunicación Audiovisual por la Universidad de Vigo, Máster en Dirección de Arte Publicitaria por la Universidad de Vigo y Técnico Superior en Realización de Audiovisuales y Espectáculos. Doctorando en el Programa de Doctorado en Creatividad e Innovación Social y Sostenible de la Universidad de Vigo, realizando la Tesis sobre nuevas formas de debate electoral en Redes Sociales.

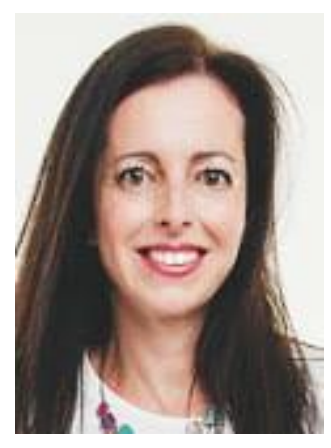

\section{BENÍTEZ DE GRACIA, MARÍA JOSÉ \\ Universidad Carlos III de Madrid \\ majbenitez@gmail.com}

Licenciada en Periodismo (Universidad Europea de Madrid, 2000) y Máster en Investigación Aplicada a los Medios de Comunicación por la Universidad Carlos III de Madrid (2016), donde realiza actualmente el doctorado sobre el reportaje inmersivo en vídeo en $360^{\circ}$, bajo la dirección de la doctora Susana Herrera. Forma parte del grupo de investigación Innovation on Digital Media, dirigido por la profesora Susana Herrera, en la Universidad Carlos III de Madrid.

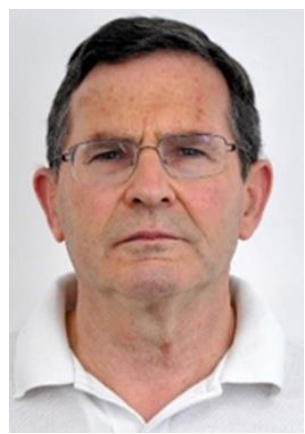

CAMPOS-FREIRE, FRANCISCO

Universidade de Santiago de Compostela

francisco.campos.freire@gmail.com

Profesor de Periodismo de la Facultad de Ciencias de la Comunicación de la Universidad de Santiago de Compostela desde 1991, función que alterna con la 
actividad periodística y gestora en la dirección del diario La Región de Ourense, la Agencia Gallega de Noticias, la Compañía de Radio y Televisión de Galicia y la presidencia de FORTA. Desde 2005 está exclusivamente dedicado a labor docente e investigadora en la Universidad de Santiago de Compostela, que compagina con estancias en otras Universidades y proyectos, entre ellos el Programa Prometeo de investigación de Ecuador (2014-16). Es miembro del Grupo de Investigación de Novos Medios de la USC y co-IP de las Redes XESCOM e INNONEWS.

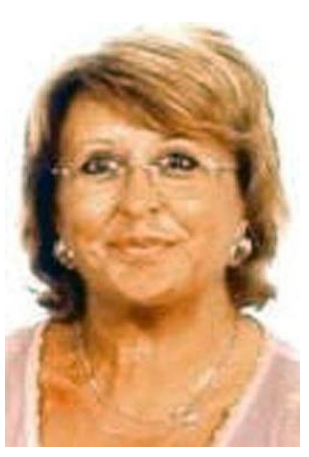

\section{CARIDAD SEBASTIÁN, MERCEDES}

\section{Universidad Carlos III de Madrid}

mercedes@bib.uc3m.es

Doctora en Ciencias de la Información, Universidad Complutense (1979). Catedrática de la Universidad Carlos III de Madrid, Facultad de Humanidades, Comunicación y Documentación, Departamento de Biblioteconomía y ha sido Vicerrectora de Extensión Universitaria de la Universidad Carlos III de Madrid desde 1994 a 2007.

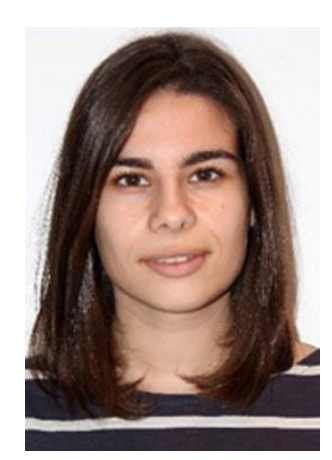

\section{CRESPO-PEREIRA, VERÓNICA}

Pontificia Universidad Católica del Ecuador Sede Ibarra

veronicacrespopereira@gmail.com

Licenciada en publicidad y relaciones públicas por la Universidad de Vigo (UVigo) y máster en producción y gestión audiovisual por la Universidad de A Coruña. Su tesis doctoral sobre la implementación de la metodología neurocientífica en el campo de la televisión ha sido realizada en la Universidad de Vigo, entidad para la que trabajó en el periodo 2015-2018. Actualmente lleva a cabo su labor como docente e investigadora en la Pontificia Universidad Católica del Ecuador Sede Ibarra. 


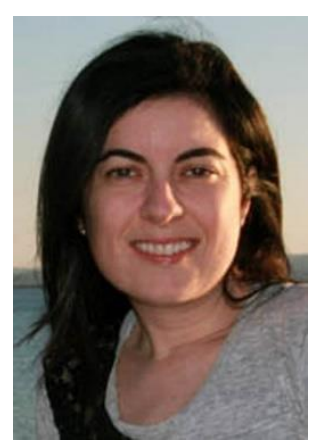

\section{COSTA-SÁNCHEZ, CARMEN}

\section{Universidade da Coruña}

carmen.costa@udc.es

Profesora de Comunicación Corporativa en el Grado en Comunicación Audiovisual de la Universidade da Coruña. Doctora en Comunicación por la Universidade de Santiago de Compostela. Premio Extraordinario de Doctorado por la Facultad de Ciencias de la Comunicación de la USC. Miembro del Grupo de Investigación en Cultura y Comunicación Interactiva de la Universidade da Coruña.

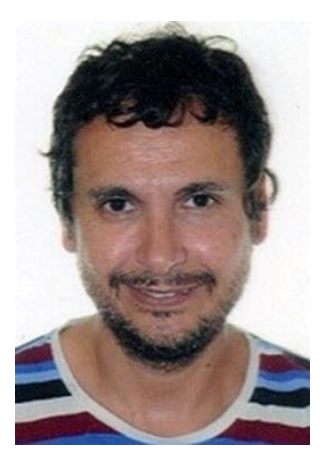

\section{FERNÁNDEZ-HOLGADO, JOSÉ}

\section{Universidad de Vigo}

xholgado@gmail.com

Graduado en Comunicación Audiovisual por la UVigo, Máster de Profesorado en Educación Secundaria por la UVigo y Técnico Superior en Realización Audiovisual y de espectáculos, por la Escuela de Imagen y Sonido de A Coruña. Doctorando en Comunicación por la UVigo, realiza una tesis sobre los valores Humanos en el medio cinematográfico.

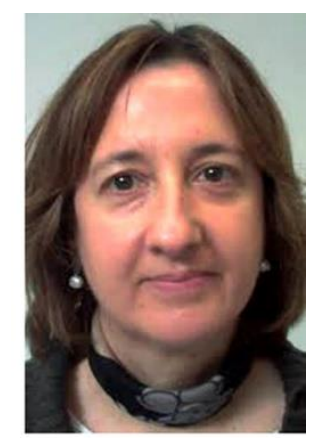

\section{GARCÍA LÓPEZ, FÁTIMA}

\section{Universidad Carlos III de Madrid}

fatimag@bib.uc3m.es

Doctora por la Universidad Carlos III de Madrid y Licenciada en Filología Hispánica por la Universidad Autónoma de Madrid. Desde 1998 viene desarrollando su labor como profesora en el Departamento de Biblioteconomía y Documentación de la Universidad Carlos III de Madrid. Integrante del grupo de investigación ACRÓPOLIS (Análisis de Contenido de 
Recursos para la Organización y Políticas de Información hacia la Sociedad del Conocimiento).

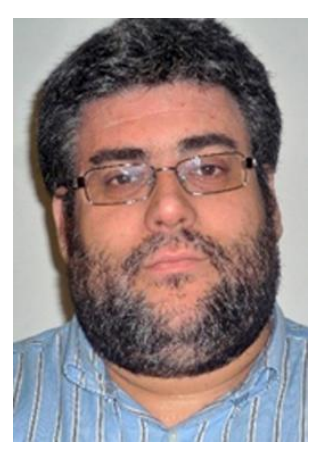

\section{JUANATEY-BOGA, ÓSCAR}

\section{Universidade da Coruña}

oscarjb@udc.es

Licenciado en Ciencias Económicas y Empresariales (1999) y Doctor en Ciencias Económicas y Empresariales por la Universidad de A Coruña (2006). Master MBA en Dirección y Administración de Empresas, Master en Dirección Comercial y Marketing, y Master en Comunicación Empresarial por la UDC.

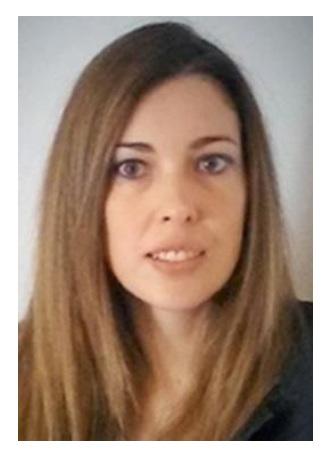

\section{LÓPEZ CEPEDA, ANA MARÍA}

\section{Universidad de Castilla-La Mancha}

ana.lopezcepeda@uclm.es

Licenciada en Periodismo por la Universidad de Santiago de Compostela (USC), Licenciada en Derecho por la Universidad Nacional de Educación a Distancia (UNED) y Doctora en Comunicación y Periodismo por la Universidad de Santiago de Compostela (USC).

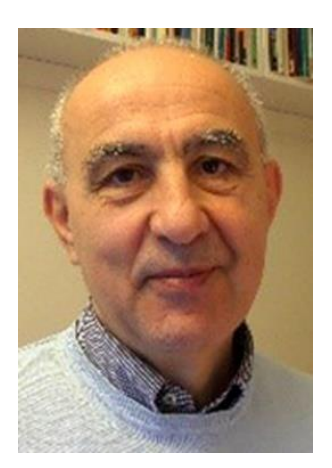

\section{LÓPEZ-GARCÍA, XOSÉ}

\section{Universidade de Santiago de Compostela}

xose.lopez.garcia@usc.es

Catedrático de Periodismo en la Universidad de Santiago de Compostela y coordinador del grupo de investigación Novos Medios. Desde el campo de los Estudios Periodísticos, estudia el Impacto de la tecnología en los cambios del periodismo. 


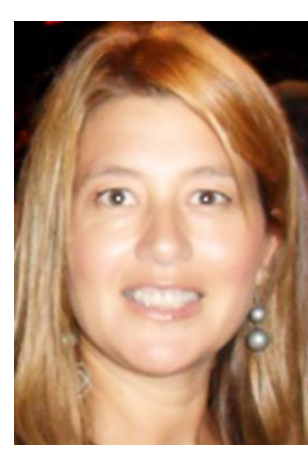

\section{LÓPEZ-GOLÁN, MÓNICA}

Pontificia Universidad Católica del Ecuador, Sede Ibarra

mlopezgol@gmail.com

Doctora en Comunicación e Industrias Creativas por la Universidad de Santiago de Compostela. Fue Directora de la Escuela de Comunicación Social de la Pontificia Universidad Católica del Ecuador Sede Ibarra. Como docente de esta escuela impartió las cátedras de Producción y Realización de Televisión. Su línea de investigación se centra en la gestión de medios, los modelos de negocio y nuevas alternativas de financiación.

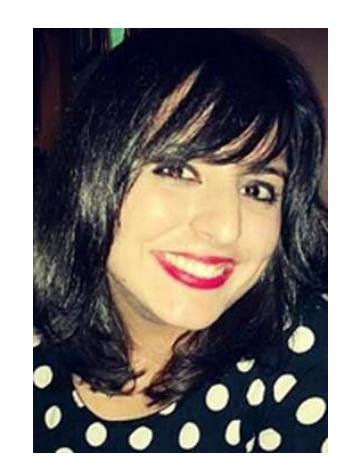

\section{MARTÍNEZ CARDAMA, SARA \\ Universidad Carlos III de Madrid}

smartin@bib.uc3m.es

Doctora con mención internacional y premio extraordinario por la Universidad Carlos III. Máster en Investigación en Documentación por la Universidad Carlos III de Madrid (2009-2011) con premio extraordinario fin de estudios. Diplomada y licenciada en documentación por la Universidad de A Coruña con premio nacional. Ha sido beneficiaria de una beca FPU del Ministerio de Educación y actualmente es profesora ayudante doctor del departamento de Biblioteconomía y Documentación de la Universidad Carlos III donde ejerce las tareas de secretaria académica. 


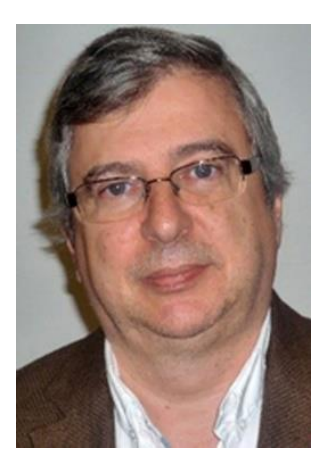

\section{MARTÍNEZ-FERNÁNDEZ, VALENTÍN- ALEJANDRO}

\section{Universidade da Coruña}

valejand@udc.es

Periodista y profesor Titular del área de Comercialización e Investigación de Mercados de la Universidad de A Coruña. Licenciado en Ciencias de la Información por la Universidad Complutense de Madrid, Máster en Dirección y Administración de Empresas (MBA) por la Universidad de A Coruña y Doctor en Ciencias de la Información por la Universidad Complutense de Madrid.

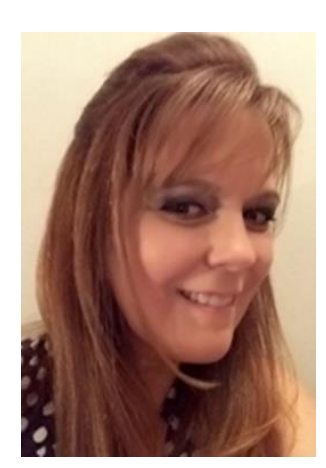

\section{MORALES GARCÍA, ANA MARÍA}

\section{Universidad Carlos III de Madrid}

amorales@bib.uc3m.es

Doctora en Documentación y Máster en Información (Universidad Carlos III de Madrid). Ha sido Vicedecana del Campus de Colmenarejo, Vicedecana de Estudios Semipresenciales y Estrategia Digital y Subdirectora del Instituto Agustín Millares. Desde 2017 es Vicedecana del Grado en Información y Documentación y Estrategia Digital. Es integrante del grupo de investigación ACRÓPOLIS (Análisis de Contenido de Recursos para la Organización y Políticas de Información hacia la Sociedad del Conocimiento).

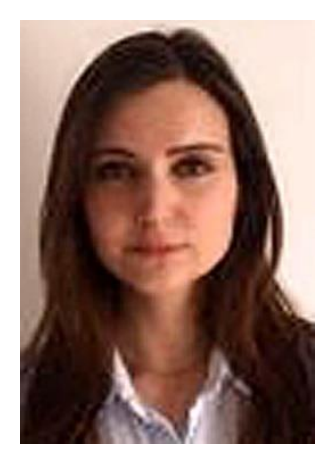

\section{PÉREZ-SEIJO, SARA}

\section{Universidade de Santiago de Compostela}

s.perez.seijo@usc.es

Investigadora del grupo Novos Medios y doctoranda en Comunicación e Información Contemporánea en la Universidade de Santiago de Compostela (USC). Actualmente es beneficiaria del programa de Formación del 
Profesorado Universitario (FPU16/06156) financiado por el Ministerio de Educación, Cultura y Deporte (Gobierno de España).

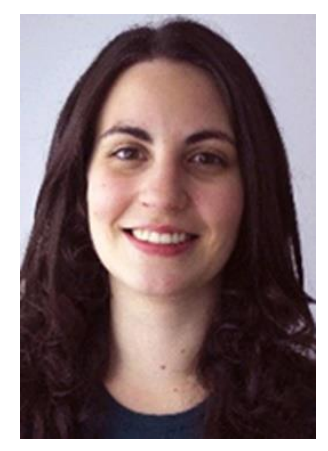

\section{RODRÍGUEZ-CASTRO, MARTA}

Universidade de Santiago de Compostela

m.rodriguez.castro@usc.es

Graduada en Comunicación Audiovisual por la Universidad de Santiago de Compostela (USC) y máster en Investigación aplicada a medios de comunicación por la Universidad Carlos III de Madrid. Actualmente es doctoranda en Comunicación e información contemporánea en la USC, donde es contratada FPU e investigadora del grupo Novos Medios.

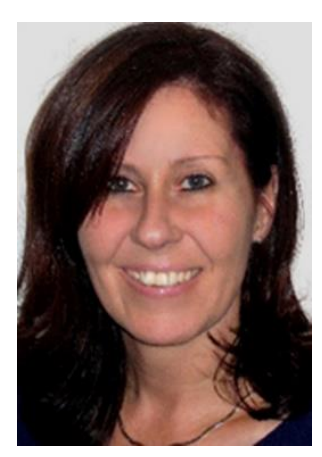

\section{RODRÍGUEZ FERNÁNDEZ, MARÍA MAGDALENA}

\section{Universidad de A Coruña}

mmrodriguez@udc.es

Doctora en Ciencias Económicas y Empresariales por la Universidad de A Coruña. Licenciada en Ciencias Económicas y Empresariales por la Universidad de Santiago de Compostela. Es profesora del Área de Comercialización e Investigación de Mercados en la Universidad de A Coruña.

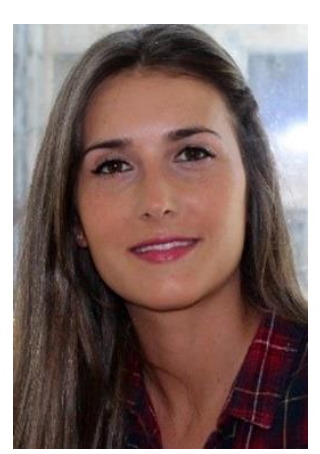

\section{SÁNCHEZ AMBOAGE, EVA Universidad de A Coruña}

eva.sanchez.amboage@udc.es

Doctora en Dirección y Planificación del Turismo por la Universidad de A Coruña. Máster en Profesorado de ESO, BAC, FP y Enseñanza de Idiomas por la Universidad de A Coruña. Máster en Dirección y Planificación del Turismo. Es profesora del Área de Comercialización e Investigación de Mercados en la Universidad de A Coruña. 


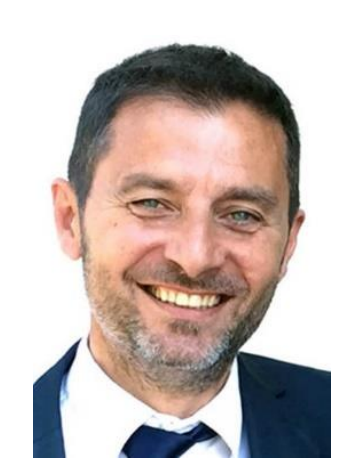

\section{TÚÑEZ-LÓPEZ, MIGUEL}

\section{Universidade de Santiago de Compostela}

miguel.tunez@usc.es

Doctor en Periodismo por la Universidad Autónoma de Barcelona y Profesor de Comunicación Organizacional y de Estrategias de comunicación en la Universidade de Santiago de Compostela. Consultor. Miembro del Grupo de Investigación Novos Medios. Premio Nacional de Periodismo Reina Sofía.

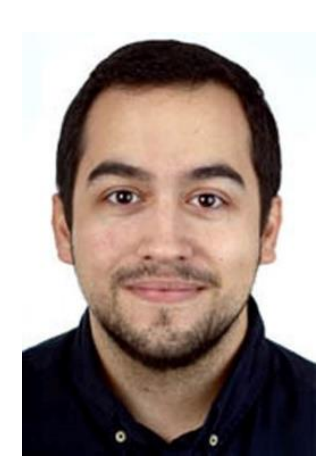

\section{VÁZQUEZ-HERRERO, JORGE}

\section{Universidade de Santiago de Compostela}

jorge.vazquez@usc.es

Doctorando en Comunicación e Información Contemporánea por la Universidade de Santiago de Compostela (España), miembro del grupo de investigación Novos Medios (USC) y de la Cátedra Latinoamericana de Narrativas Transmedia (Universidad Nacional de Rosario, Argentina). Investiga sobre narrativas digitales de no ficción interactiva, centrándose en el documental interactivo y las narrativas interactivas en los cibermedios.

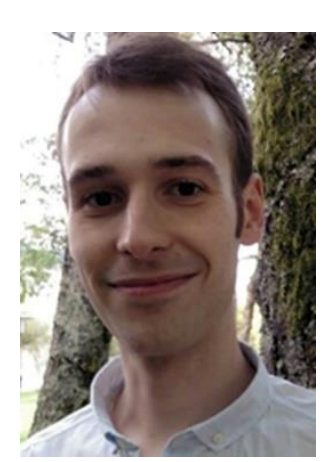

\section{VIZOSO, ÁNGEL}

\section{Universidade de Santiago de Compostela}

angel.vizoso@usc.es

Graduado en Periodismo por la Universidad de Santiago de Compostela, doctorando del Programa de Doctorado en Comunicación e Información Contemporánea e investigador en formación en la misma Universidad. Sus líneas de investigación se centran en el estudio de la visualización de la información, la verificación y los perfiles profesionales. 